\title{
Essays on Civil Conflict, Political Regimes, and Natural Endowments
}

\section{Satyendra Kumar Gupta}

School of Humanities and Social Sciences

\begin{abstract}
A thesis submitted to the Nanyang Technological University in partial fulfilment of the requirement for the degree of Doctor of Philosophy
\end{abstract}




\section{Acknowledgement}

Undertaking this Ph.D. course has been a good experience for me and this would have not been possible without the help of many people.

I would like to express my deepest appreciation for my dissertation supervisor Associate Professor James B. Ang. I had no experience of working in field of economic growth, and political economy. I went to him with an open mind to work on any topic that suited his research agenda at that time. Fortunately, I was the first Ph.D. student he had after joining at Nanyang Technological University (NTU) Singapore. It enabled to me take advantage of his relatively less busy schedule. Over the two years, he has helped me in understanding the field. Without his guidance and persistent help this dissertation would not have been possible.

I am grateful to my dissertation co-supervisor Assistant Professor Giovanni Ko for his helpful feedback and support during writing chapters of my thesis. I also wish to thank my PhD thesis committee members Associate Professor Joseph Alba, and Assistant Professor Rudrani Bhattacharya for their feedback at various stages of writing this thesis.

The best part of working at the NTU student office during the Ph.D. has been the opportunity to spend some quality time with other Ph.D. students here. Most of them are from East Asia, Japan, and China. It was good to observe different styles of work, and culture. I would like to say special thanks to fellow Ph.D. student Zakaria Rehman for giving company while walking back to our respective residences. Also, it was good to have occasional beer on the way back to our rooms. 
I am also grateful to other faculty and administrative staff who were always helpful and accommodating to my requests. Special thanks to Juliana who was the point of contact for any kind of administrative queries even before I joined Ph.D. program. I would like to say heartfelt thanks to my parents and brother for always believing me and letting me follow my interests.

I would also like to thank my little daughter Megha who continued to believe that I was in office like her mother goes everyday whenever I was in Singapore.

Last but not the least, I would like to thank my wife Oindrila who inspired me to start a career in economics. At many occasions, she silently suffered, but let me fly to Singapore every time after my short visits so that I could concentrate on my research and finish this Ph.D. thesis. Without her support and encouragement, I would not have been able to come so far. 


\section{Table of Contents}

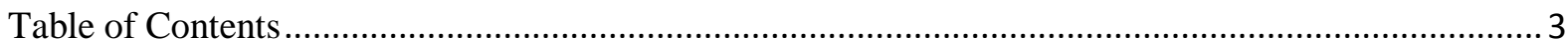

$1 \quad$ Summary

2 Uncovering the Deep Roots of Conflict................................................................................. 9

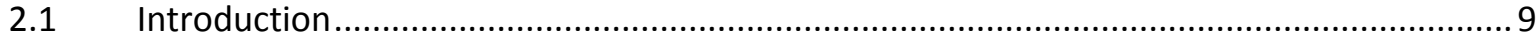

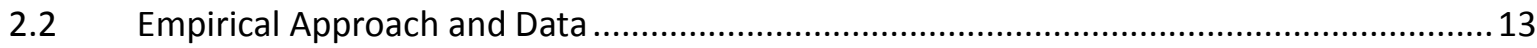

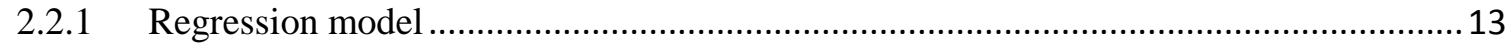

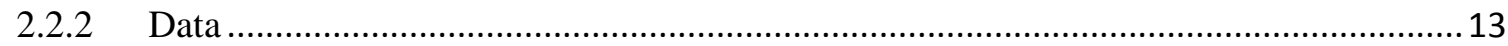

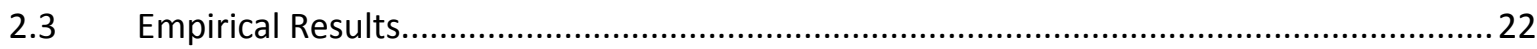

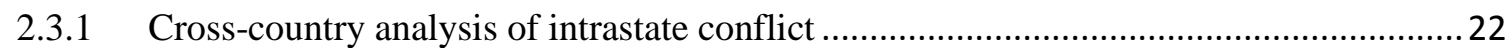

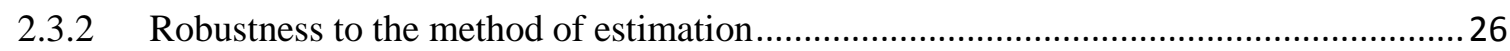

2.3.3 Robustness to alternative definitions of conflict ............................................................... 26

2.3.4 Robusness to controlling for the effects of early development ......................................28

2.3.5 Robustness to the inclusion of additional control variables ........................................... 30

2.3.6 Robustness to elimination of regions from estimation sample......................................... 33

2.4 Further Analyses Using Repeated Cross-country Data...................................................... 34

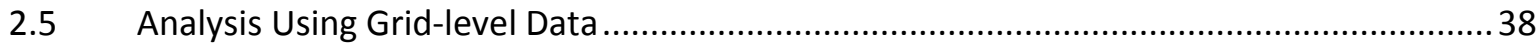

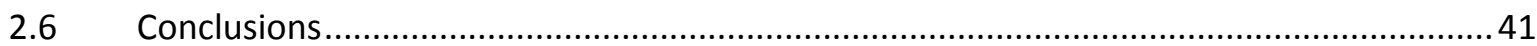

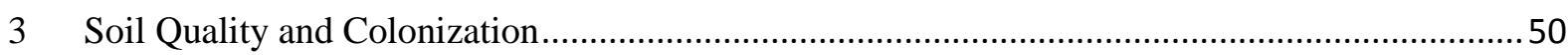

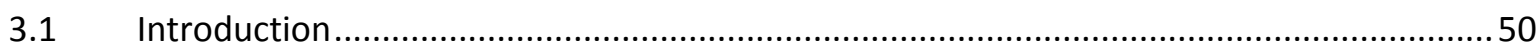

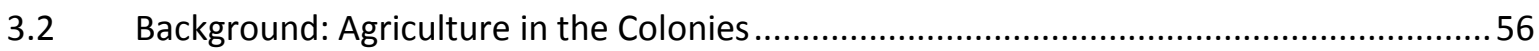

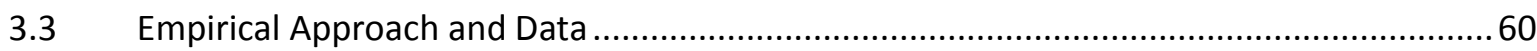

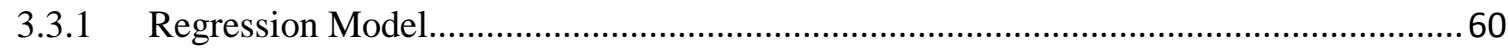

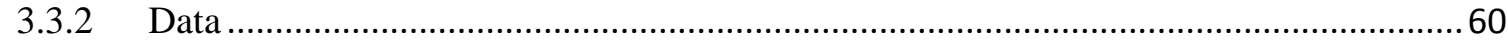

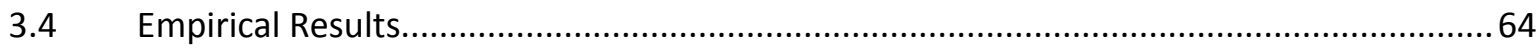

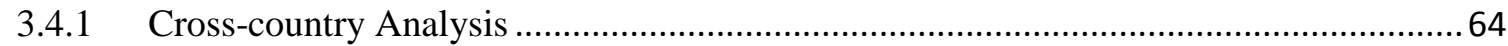

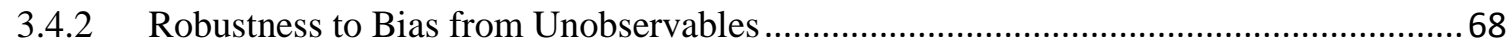

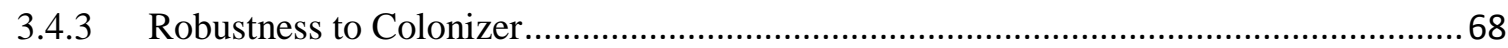

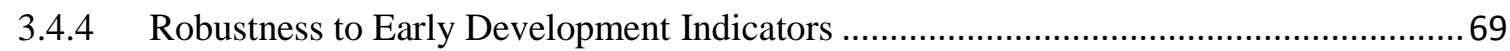

3.4.5 Robustness to the Inclusion of Other Covariates ........................................................ 74

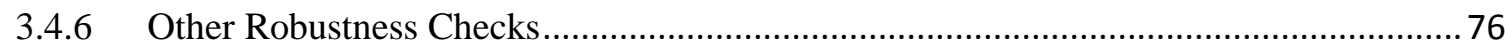




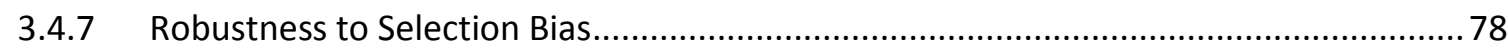

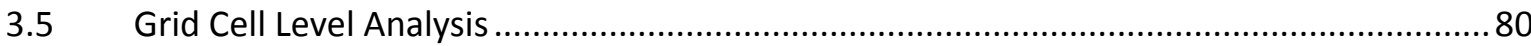

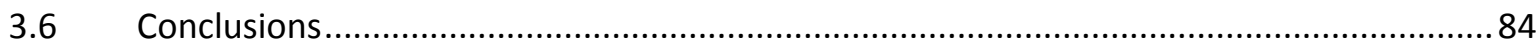

4 The Long-run Effects of Agriculture Productivity on Democracy ……......................................90

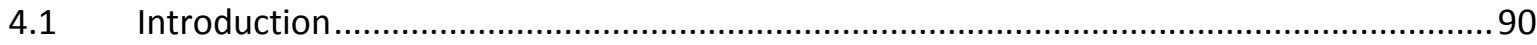

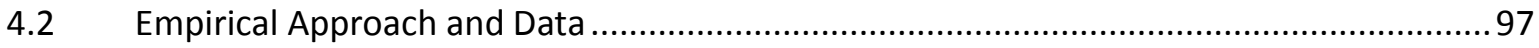

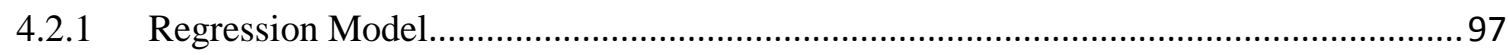

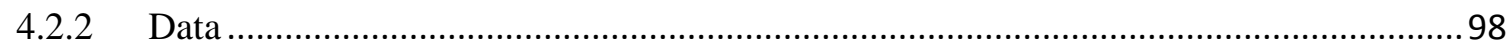

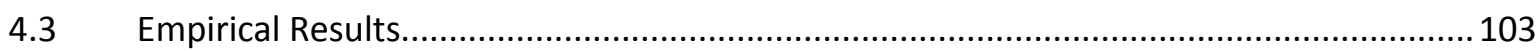

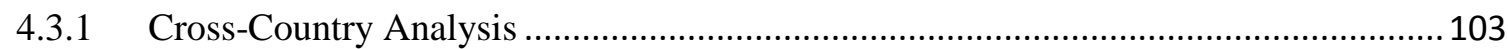

4.3.2 Robustness to Alternative Measures of Democracy.................................................... 105

4.3.3 Robustness to Institutions and Early Development..................................................... 112

4.3.4 Robustness to Contemporary Development and Social Cleavages ............................... 120

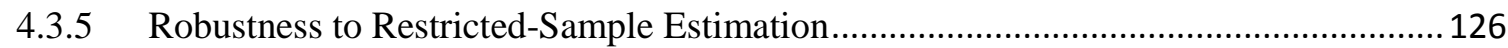

4.4 Evidence from Precolonial Indigenous Societies .......................................................... 128

4.5 Transmission of Democracy from Precolonial Societies to Modern Nation-

States 130

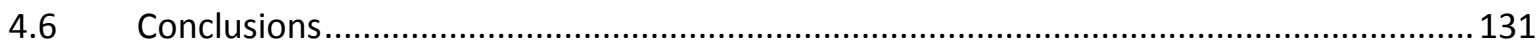

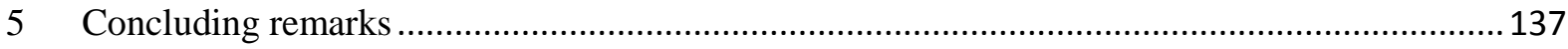


Index of Tables

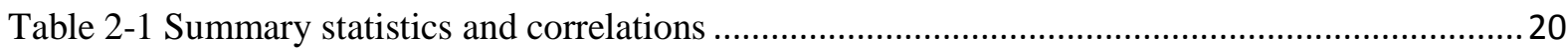

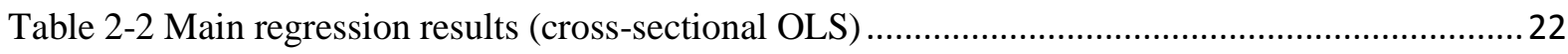

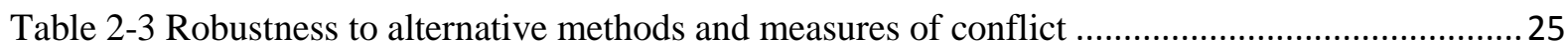

Table 2-4 Robustness to controlling for the effects of early development ..........................................28

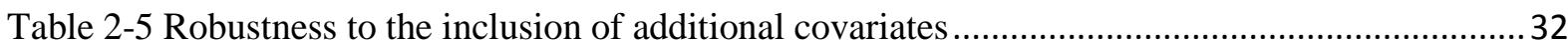

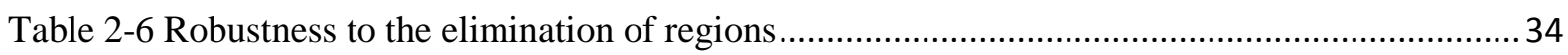

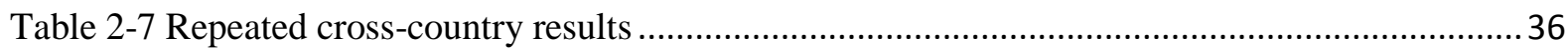

Table 2-8 Repeated cross-sectional results for conflict incidence severity ......................................... 38

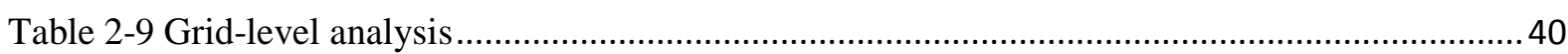

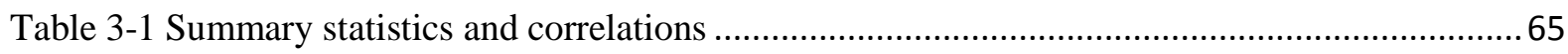

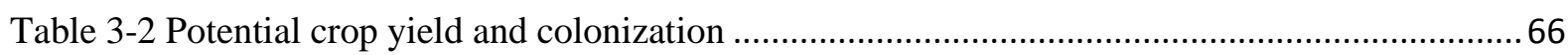

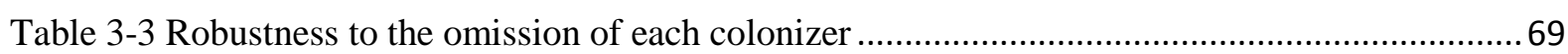

Table 3-4 Robustness to early development (average crop yield and years since

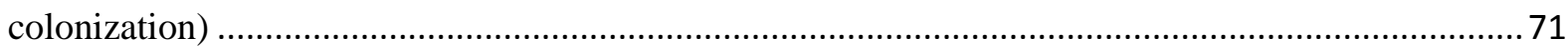

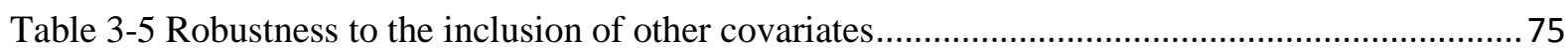

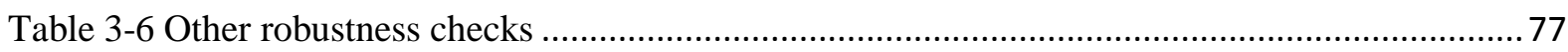

Table 3-7 Potential crop yield and colonization: Heckman Selection Model ....................................... 79

Table 3-8 Average crop yield and colonization (Grid size 1 by 1 decimal degree) ................................83

Table 4-1 Crop yield on democracy after accounting for geographical controls .................................104

Table 4-2 Influence of crop yield on democracy (alternative measures of democracy

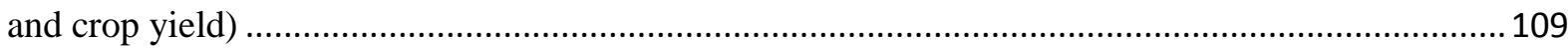

Table 4-3 Influence of crop yield on democracy after accounting for institutions and

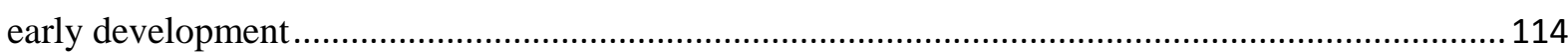

Table 4-4 Influence of crop yield on democracy after accounting for early

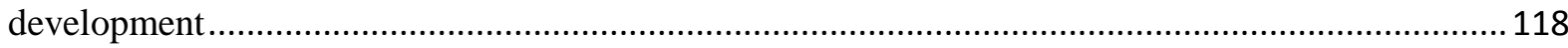

Table 4-5 Influence of crop yield on democracy after accounting for contemporary

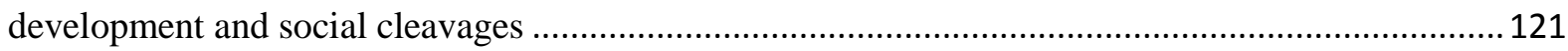

Table 4-6 Influence of crop yield on democracy after omitting various regions .................................127

Table 4-7 Crop yield on democracy in Standard Cross Cultural Sample (SCCS) .............................129 
Index of Figures

Figure 2-1 Histogram of variation in crop yield

Figure 2-2 The relationship between conflict incidence and variation in potential crop

yield

Figure 2-3 Relationship between conflict incidence and crop yield variation...................................24

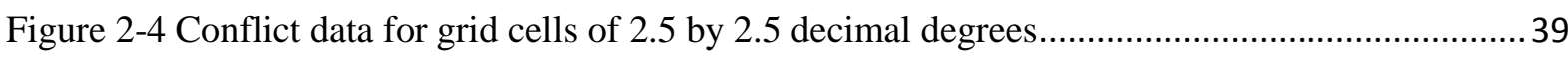

Figure 3-1 The association between colonization timing and average crop yield ................................66

Figure 3-2 The association between colonization duration and average crop yield ...........................67

Figure 4-1 Distribution of democracy and potential crop yield across 147 countries ......................... 102

Figure 4-2 Scattered plot of potential crop yield and democracy during 1961-2015 .........................105

Figure 4-3 Linear relationship of piece-wise potential crop yield and democracy

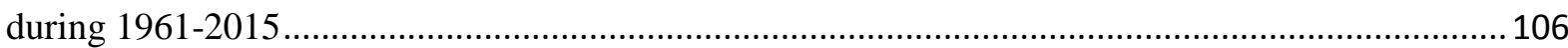




\section{Summary}

History is important in understanding cultural traits and the quality of institutions across countries. Transformation to sedentary agricultural practices was a key historic event in human history. Gradually, agriculture became an important activity for sedentary societies, and consequently, land productivity became the most important resource for agriculture in the societies. This study measures land productivity by potential crop yield. The potential crop yield index is constructed using crop yield (measured in tons per hectare per year) from the Global Agro-Ecological Zones (GAEZ) project from the Food and Agriculture Organization (FAO) and the caloric content of various crops from the US Department of Agriculture Nutrient Database for Standard Reference (source: Galor and Özak (2016)).

In the first chapter, I hypothesize that as societies started fighting over control of the most productive land, a culture of violence and conflict developed. The empirical results establish that the emergence and persistence of intrastate conflict incidence since 1960 were influenced by regional agro-ecological factors captured by the extent of variation in crop yield potential. Our results, based on cross-country and grid-level analysis, indicate that higher potential crop yield variability within a country that is exogenous to both human intervention and regional culture increases the likelihood of intrastate conflict. Our findings are strengthened by the inclusion of various geographical, institutional, and potentially confounding economic development correlates.

In the second chapter, I focus on colonization by the Western European powers after the discovery of the New World. I hypothesize that the timing and duration of colonization was strongly influenced by regional land productivity. In particular, an area's potential average crop yield is shown to have an significant and influential 
effect on the timing and duration of colonization, where more fertile areas tended to be colonized earlier and had a longer period of colonization. The results are consistent with historical evidence such as the quest for new territories in order to produce sugar, tea, timber, and other commodities. These efforts supported industrial growth in Europe, which provided its population with the calories needed. My findings are bolstered by the inclusion of other indicators of early development, as well as the geographical and ecological conditions that were important for European settlement in the colonized territories. My hypothesis is also supported by a grid-cell level analysis, which mitigates any endogeneity concern in the cross-country analysis. In the third chapter, I argue that an optimal level of potential crop yield is inductive of a democratic political regime. Empirical results establish a humped shaped association between crop yield and the extent of democracy in a cross-country analysis. These findings are supported by the inclusion of other possible confounders such as: the quality of institutions, indicators of early development, and various other determinants of democracy identified in extant literature. The hypothesis is also supported by sub-national and pre-colonial societies' datasets.

The next three chapters identify and empirically establish the role of land productivity in the emergence of culture of conflict, the occurrence of important historic events, and the development of modern institutions. The last chapter of this Ph.D. dissertation draws the necessary conclusions. 


\section{Uncovering the Deep Roots of Conflict}

\subsection{Introduction}

Intrastate conflict is a profound reality in many parts of the world. It is so phenomenally evident that nearly half of the countries in the world have experienced at least one incidence of it over the last few decades. The resulting loss of human capital and undesirable outcomes associated with the geographical spread of violence have attracted the attention of many economists, social scientists, and psychologists to understand the roots of civil conflicts.

In economics the rational behavior argument that one engages in conflict only when the opportunity cost of doing so is less than that of peaceful cooperation or negotiation has been the focus when determining the root cause of conflicts. Slow economic growth and low per capita income are notable signs of low opportunity cost and people facing such circumstances are more likely to participate in violence (Collier and Sambanis, 2002; Blattman and Miguel, 2010). Slower growth and per capita income can, in turn, be linked to lower agricultural productivity, which is often induced by variation in rainfall, temperature, and soil quality. In particular, adverse climate conditions may impact agricultural productivity, which reduces the opportunity cost of initiating and engaging in conflict and civil wars (see, e.g., Collier and Hoeffler, 1998; Collier and Hoeffler, 2004).

Recent studies have taken the above arguments further by providing evidence on how natural conditions play an important role in the onset of conflict and ongoing conflict incidence in a region. Natural rainfall was, and still is, in many parts of the developing world, the dominant source of water supply for agriculture in the absence of efficient irrigation systems. Thus, several studies have explored the association 
between variation in rainfall and agricultural productivity to explain conflicts and rebellions in cross-country and within-country analysis. For example, Miguel et al. (2004) provide evidence showing that extreme weather conditions are strongly associated with the occurrence and incidence of conflict. They find a positive relationship between extreme rainfall variation on the frequency of rebel and communal conflict in Africa. Chaney (2013) shows that significant deviation above or below the optimal flood level of the Nile triggered political instability in historical Egypt. Brückner (2010) also shows that droughts (periods of low rainfall) can reduce the probability of intrastate civil conflicts through population reduction in SubSaharan countries.

Other studies have shown that temperature and the occurrence of conflict are strongly related. In particular, Dell et al. (2012) find that the annual variation in temperature is strongly linked to standards of living, where for every one degree Celsius increase in temperature per capita income is predicted to fall by 1.4 percent in poor countries. Similarly, Schlenker and Lobell (2010) find that variation in temperature and precipitation during yield time negatively affects agriculture productivity in African countries. Analyses using data from historical temperate and cold locations conducted by Zhang et al. (2007) show that anomalously cold events during cold epochs are associated with episodes of political instability in dynastic China and feudal Europe. In a similar vein, Hsiang et al. (2011) find that $21 \%$ of all the civil conflicts since 1950 could be attributable to the warmer and dryer weather in the continental tropics caused by El Nino/Southern Oscillation (ENSO).

This study extends the strand of literature that explores the influence of climate variables on long-term development. We argue that agricultural productivity potential has played a significant role in shaping the direction of human history following the 
agricultural transition. The agroecology of a region, until the advent of modern agricultural techniques such as fertilizers, mechanized farming tools, and irrigation facilities, determined the level of calories one could get in any region. Building on this insight, we hypothesize that there would be frequent and persistent attempts to conquer and control territories that produce high caloric yield. Higher regional variation in caloric yield should therefore increase the frequency of these conflicts to control the most valuable resource in pre-industrial societies. Specifically, we demonstrate that the variation in agroecology, measured as the standard deviation in crop yield (in millions of kilocalories per hectare per year), within a country based on the data of Galor and Özak (2016), has a significant positive effect on conflict incidence. $^{1}$

Our work is closely related to that of Galor and Özak (2015), who provide evidence that, in comparison with another commonly used land productivity measure (i.e., agricultural suitability), ${ }^{2}$ mean crop yield is more strongly correlated with preindustrial population density, which determines the path of subsequent development. ${ }^{3}$ Galor and Özak (2016) also provide new evidence showing that pre-industrial agroclimatic characteristics that were favorable to agricultural productivity, proxied by

\footnotetext{
${ }^{1}$ The crop yield index is a composite measure that takes into account the effect of temperature and moisture on the growth of 48 crops. Potential yield estimation for each crop in each agroclimatic grid (with cell size of approximately $100 \mathrm{~km}^{2}$ ) is provided by the Global AgroEcological Zones (GAEZ) project of Food and Agriculture Organization (FAO). For detailed description of the crop yield data, see Galor and Özak (2015).

2 The agricultural suitability indices have been used in a number of research studies on long-term development, including but are not limited to Michalopoulos (2012), Ashraf and Galor (2013), Ang (2015), Ashraf and Michalopoulos (2015) and Olsson and Paik (2016).

${ }^{3}$ Other related studies by Depetris-Chauvin and Özak $(2015,2016)$ show that population density affects the division of labor and economic specialization, which in turn result in the formation of institutions and states.
} 
agricultural crop yield, induced learning processes that have had a persistent effect on the formation of long-term orientated cultures in the modern day.

Our study is also complementary to the contribution of Nunn and Qian (2014), who investigated the implication of humanitarian food aid on conflict. They argue that armed rebels often steal US food aid or it is appropriated by the military of the ruling government, and hence an increase in aid may exacerbate civil conflict in recipient countries. Using a novel identification strategy, their results provide strong support for the view that higher US wheat aid tends to increase the incidence and duration of civil conflicts. In a similar vein, Arbatli et al. (2015) demonstrate that genetic diversity has a robust and persistent effect on the frequency, incidence, and onset of civil conflicts. However, unlike Nunn and Qian (2014) and Arbatli et al. (2015) who examine the roles of contemporary wheat aid and genetic diversity, respectively, a main departure of our study is that we focus on whether the variability of preindustrial agricultural productivity can potentially account for the persistent occurrence of conflict.

The rest of the paper is organized as follows. Section 2.2 sets out the approach and describes the data. Section 2.3 presents and discusses the empirical results. Some robustness tests are also performed. Section 2.4 presents empirical results for repeated cross-section data. In section 2.5, we divide the world into small grids of 2.5 by 2.5 decimal degrees to address potential concerns of endogeneity. We find that the incidence of conflicts in each grid cell over the period 1989-2015 can be explained by variation in potential (average) crop yield in respective grid cells after accounting for other geographical characteristics. The last section concludes the paper. 


\subsection{Empirical Approach and Data}

\subsubsection{Regression model}

We estimate the following regression model to evaluate the influence of variation in crop yield on conflict incidence:

$$
\begin{aligned}
\text { Conflict }_{i}=\alpha & +\beta \text { sd_cropyield }_{i}+\text { ravg_cropyield }_{i}+\delta \text { Controls }_{i} \\
& +\epsilon_{i}
\end{aligned}
$$

where Conflict $_{i}$ is the average number of 5-year sub-periods that experience any conflict in country $i, s_{-}$cropyield ${ }_{i}$ is the log of variation in potential (average) crop yield across cells (measured in millions of kilocalories per hectare per year) in country $i$, avg_cropyield $i$ is the log of mean potential (average) crop yield across cells in country $i$, Controls $s_{i}$ is a vector of control variables included in the regressions to minimize the possibility of getting spurious estimates, and $\epsilon_{i}$ is the error term. We expect $\beta$ to be positive and statistically significant. Our baseline sample used in the cross-country analysis consists of data for up to 135 countries.

\subsubsection{Data}

\section{A. Outcome measures}

The dependent variables are constructed using data over the period 1960-2014. We follow the common practice in the existing literature by focusing on the post-1960 period, given that most of the former European colonies in Sub-Saharan Africa, Middle East, South and East Asia gained independence since 1960. This is to reduce the possibility that the results are confounded by colonial powers influencing the domestic decision in these countries. Furthermore, as it is the common practice in the existing literature on conflict, we divide the time period of study; 1960 to 2014, into eleven non-overlapping 5-year sub-periods. 
Our main source of data for ongoing conflict incidence and the onset of new conflict are the Armed Conflict Dataset, version 4-2015 and Conflict Onset and Incidence Dataset (Pettersson and Wallensteen, 2015), both of which are taken from Uppsala Conflict Data Program (UCDP). UCDP defines conflict as "a contested incompatibility that concerns government and/or territory where the use of armed force between two parties, of which at least one is the government of a state, results in at least 25 battle-related deaths." As a consequence, any conflict episode where the number of battle deaths is less than the prescribed threshold is not recorded in this dataset. These two datasets provide an annual binary indicator of whether the threshold of 25 battle-related deaths has been exceeded in that year.

Conflict incidence. We use intrastate conflict incidence variables from Armed Conflict Dataset. Our main outcome variable is confinc that takes value 1 when there is at least one conflict of any intensity in any year within a 5-year sub-period; otherwise, it is 0 . This is the main outcome variable used in our baseline estimations. Additionally, we use two other binary variables that are defined using different thresholds. Specifically, confinc_mid takes a value of 1 when there is at least one conflict episode having battle-related deaths of less than one thousand in a single year, but having cumulative battle-related deaths exceeding one thousand since the beginning of the episode in any year within a 5-year sub-period; otherwise it is 0 . confinc_war takes a value of 1 when there is at least one conflict episode having battle-related deaths exceeding one thousand in a single year in any year within the 5year sub-period; otherwise it is 0 . For the simple cross-country analysis, we use the sum of the respective conflict incidence outcome variables across the 11 sub-periods. Thus, the outcome variables have values ranging between 0 and 11 .

The onset of conflict. We also use intrastate conflict onset variables from Conflict 
Onset and Incidence Dataset. One issue with the data is that the onset of conflict could reflect an increase in battle-related deaths from less than 25 to more than 25 in an ongoing conflict, rather than the onset of a new conflict. Despite this limitation, Conflict Onset, and Incidence Dataset is the best available data to measure the onset of the new conflict. To overcome the impact of measurement errors in recording the onset of a new conflict, we create two new variables using the Conflict Onset and Incidence Dataset. These variables, labeled as onset 2 and onset 5 , take a value of 1 if a new episode of conflict starts after 2 and 5 years of 'peace', respectively, in each of the five-year periods. We take the aggregate values over the eleven periods and use them as our onset variables in the simple cross-sectional analysis.

Ethnic conflict. As all civil conflicts are generally not ethnic-driven, using the UCDP dataset, Wimmer et al. (2009) have created a unique conflict dataset that focuses only on ethnic conflicts. They coded the aim of each rebel organization and indicated whether they pursued ethno-nationalist aims and recruited along ethnic lines. They identify "ethnic" as aiming to achieve ethnonational self-determination, a more favorable ethnic balance-of-power in government, ethno-regional autonomy, the end of ethnic and racial discrimination, language and other cultural rights, and the likes. In ethnic wars, armed organizations also recruit fighters predominantly among their leaders' ethnic group and forge alliances on the basis of ethnic similarity. We use the latest version of their dataset covering the period from 1960 to 2010 to obtain a measure of new ethnic conflict.

Non-state conflict. All the alternative definitions and different thresholds of minimum battle-related deaths that have been considered so far are based on the data where one side of the conflict is the government or the state forces, fighting against one or more internal armed opposition groups. These conflict incidences are more severe and 
prevalent in the conflict data. However, government or state forces may not be involved in all intrastate conflicts. In many countries, people give preference to members of their own political party, ideology, tribe, religion, and ethnicity. Even when these groups are not fighting against the state, there are many intergroup conflicts where two or more groups fight with each other and such conflict is recorded as non-sate conflicts when the threshold of twenty-five battle-related deaths is crossed. Consequently, we use the UCDP non-state conflict dataset ${ }^{4}$, Version 2.52014, 1989-2013 (Sundberg et al. 2012), to obtain a measure of non-state conflict incidence.

\section{B. Main explanatory variable (variation in potential average crop yield)}

As discussed earlier, our independent variable in both reduced-form, cross-country, and repeated cross-country analyses is variation in potential crop yield. This index captures variation in potential crop yield (measured in millions of kilocalories per hectare per year) across different regions in each country. It addresses the limitations of other available weight-based agricultural yield indices. For example, the land productivity index constructed by Ramankutty et al. (2002), does not reflect the fact that equally suitable land can have a large variation in crop yield since caloricintensive crops may not be cultivated in some regions (see Galor and Özak, 2015).

\footnotetext{
${ }^{4}$ For example, between paramilitary United Self-Defense Forces of Colombia (AUC) and the guerrilla Revolutionary Armed Forces of Colombia (FARC) in Colombia, or between the competing rebel groups National Patriotic Front of Liberia (NPFL) and United Liberation Movement of Liberia for Democracy (ULIMO) in Liberia ; clashes between supporters of the All Nigeria People's Party and supporters of the People's Democratic Party in Nigeria; between groups that define themselves along identity lines, be it ethnic, clan, religious, national, or tribal identities. Fighting between these types of groups captures what is commonly referred to as communal conflict, such as Hindu-Muslim riots in India.
} 
The data on crop yield are taken from Galor and Özak (2016), who construct their dataset from the Global Agro-Ecological Zones (GAEZ) project of the Food and Agriculture Organization (FAO). GAEZ supplies global yield and growth cycle estimates for 48 crops in grids with cells size of 5'x5' (approximately $100 \mathrm{~km}^{2}$ ). ${ }^{5}$ GAEZ supplies crop yield estimates for each crop based on three alternative levels of input - high, medium and low - and two feasible sources of water supply - rain-fed water supply and irrigation. The FAO dataset supplies potential yield estimates for each crop in each agro-climatic grid while accounting for the effect of temperature and moisture on the growth of the crop.

The crop yield index is constructed using a low level of inputs and rain-fed agriculture cultivation methods in order to account for the agricultural conditions that were prevalent during the pre-industrial era. This reflects farming practices prevalent during the early stages of development. Furthermore, the crop yield data are based on agroclimatic conditions that are independent of any human intervention. This, therefore, mitigates any potential endogeneity pertaining to agricultural inputs, irrigation method, and soil quality with the events of conflict.

Each crop yield in the GAEZ data (measured in tons per hectare per year) is converted by Galor and Özak (2016) into caloric yield (millions of kilocalories per hectare per year) to represent the nutritional variation across crops and to compare crop yields among different crops. The US Department of Agriculture Nutrient Database for Standard Reference provides data on the caloric content of various

\footnotetext{
${ }^{5}$ These 48 crops are alfalfa, banana, barley, buckwheat, cabbage, cacao, carrot, cassava, chickpea, citrus, coconut, coffee, cotton, cowpea, dry pea, flax, foxtail millet, greengram, groundnuts, indigo rice, maize, oat, oilpalm, olive, onion, palm heart, pearl millet, phaseolus bean, pigeon pea, rye, sorghum, soybean, sunflower, sweet potato, tea, tomato, wetland rice, wheat, spring wheat, winter wheat, white potato, yams, giant yams, subtropical sorghum, tropical highland sorghum, tropical lowland, sorghum, white yams.
} 
crops. Using these measures, the estimated average regional crop yield reflects the average regional levels of two variables - crop yield and crop cycle - among crops that indicate the average caloric yield in each cell. Our analysis focuses on the averages across cells where the average potential crop yield is positive. We take logs on the standard deviation of potential (average) crop yield for all the grids in a country and use it as our measure of variation in potential (average) crop yield.

Figure 2-1 plots the distribution of variation in crop yield for all the countries in the sample. The bottom decile of countries has a variation below 62.60 , while the top decile has a variation of over 674.56. Countries in Middle-East Asia and North Africa (e.g., Israel, Qatar, Saudi Arabia, UAE, and Oman) typically have very low levels of variation in crop yield whereas some mountainous or geographically large countries such as the U.S., Argentina, Nepal, Bhutan, and China, are at the other end of the spectrum. Figure 2-2 shows that conflict incidence and variation in crop yield displays a positive relationship.

Figure 2-1 Histogram of variation in crop yield

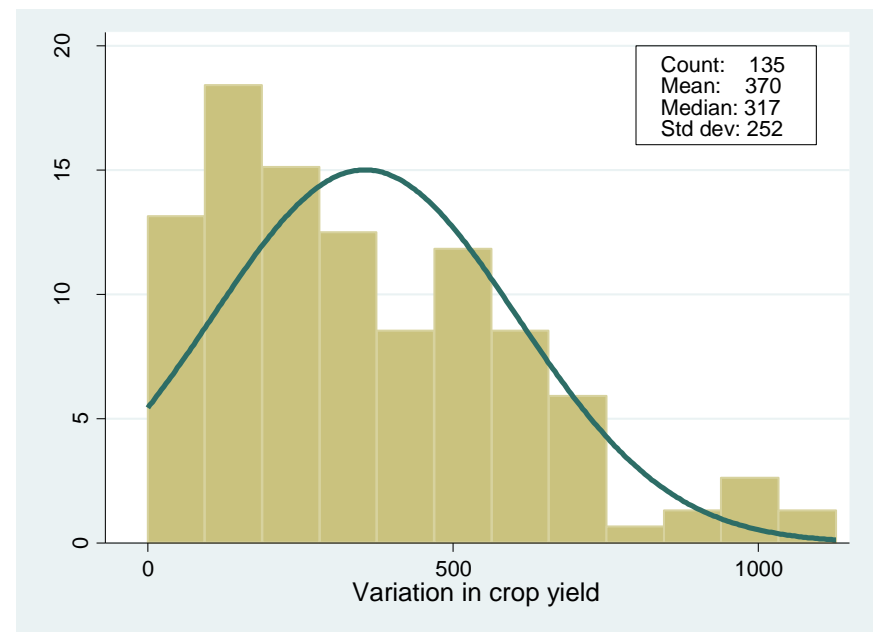

Notes: The horizontal axis measures variation in potential crop yield across the globe, as measured in millions of kilo calories per hectare per year, based on the crops that were available after Colombian exchange (source: Galor and Özak, 2016). 
Figure 2-2 The relationship between conflict incidence and variation in potential crop yield

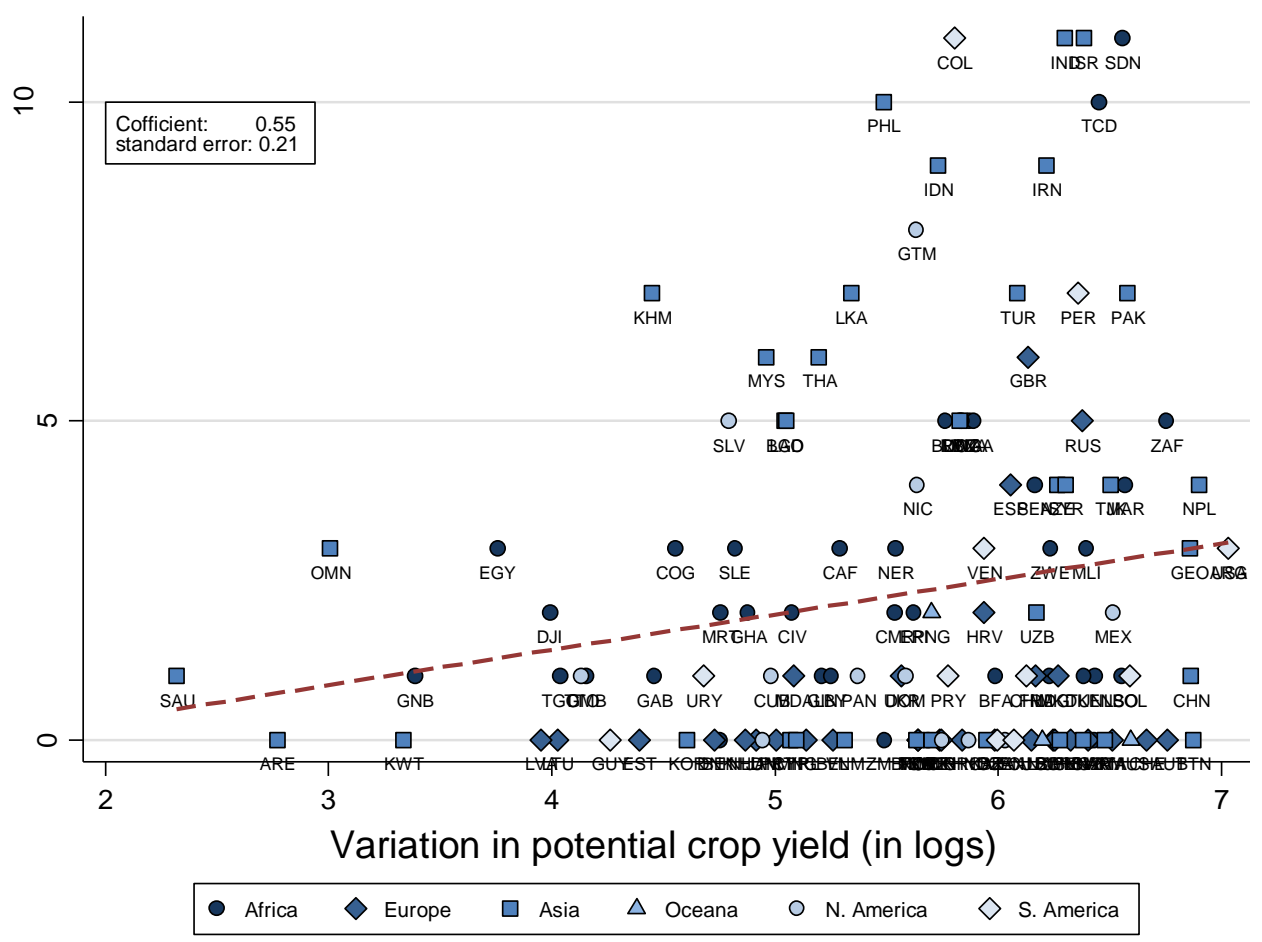

Notes: Conflict incidence is number of five year sub-periods, between 1960 and 2014, that had at least one ongoing conflict of any intensity. The $\mathrm{x}$-axis measures variation in potential crop yield across the globe, as measured in millions of kilo calories per hectare per year, based on the crops that were available after Colombian exchange. The number of countries included is 135 (source: Galor and Özak, 2016).

\section{Control variables}

Mean potential (average) crop yield is included in all regressions. The computation of this variable is similar to the way variation in potential (average) crop yield is constructed, except for the fact that it represents the mean of potential (average) crop yield over all the cells in a country. Several other control variables which may potentially confound the relationship between variation in crop yield and conflict incidence are included in the regressions. This includes terrain ruggedness, absolute latitude, elevation, distance to nearest waterway, precipitation, landlockedness, mean 
elevation, temperature and the percentage of population living in tropical zones. We also include continent dummies to account for any omitted variable bias of timeinvariant continent-specific geographical, cultural and historical characteristics. Summary statistics and the correlations of the variables are given in Table 2-1.

\section{Table 2-1 Summary statistics and correlations}

\begin{tabular}{lccccc}
\hline Summary Statistics & No. of observations & Mean & Standard deviation & Minimum & Maximum \\
\hline Conflict incidence & 135 & 2.3 & 2.9 & 0 & 11 \\
Variation in crop yield & 135 & 369.6 & 252.3 & 9.2 & 1127.3 \\
Mean crop yield & 135 & 1207.4 & 649.7 & 0.5 & 2742.8 \\
Terrain ruggedness & 135 & 0.2 & 0.2 & 0.0 & 1.0 \\
Absolute latitude & 135 & 0.3 & 0.2 & 0.0 & 0.7 \\
Elevation & 135 & 0.6 & 0.5 & 0.0 & 2.7 \\
Distance to waterways & 135 & 0.3 & 0.5 & 0.0 & 2.4 \\
Precipitation & 135 & 86.6 & 59.3 & 2.9 & 260.0 \\
Landlockedness & 135 & 0.3 & 0.4 & 0.0 & 1.0 \\
Temperature & 135 & 17.9 & 8.5 & -7.9 & 28.6 \\
$\%$ of pop in tropical zones & 135 & 0.3 & 0.4 & 0.0 & 1.0 \\
\hline
\end{tabular}


Table 2-2 Summary statistics and correlations (continued)

\begin{tabular}{lccccccccccc}
\hline Correlation Matrix & $(1)$ & $(2)$ & $(3)$ & $(4)$ & $(5)$ & $(6)$ & (7) & (8) & (9) & (10) & (11) \\
\hline (1) Conflict incidence & 1 & & & & & & & & & & \\
(2) Variation in crop yield & 0.14 & 1 & & & & & & & & \\
(3) Mean crop yield & -0.13 & -0.05 & 1 & & & & & & & & \\
(4) Terrain ruggedness & 0.21 & 0.43 & 0.06 & 1 & & & & & & \\
(5) Absolute latitude & -0.32 & 0.21 & -0.02 & 0.11 & 1 & & & & & & \\
(6) Elevation & 0.07 & 0.58 & -0.1 & 0.68 & -0.02 & 1 & & & & \\
(7) Distance to waterways & 0.09 & 0.20 & -0.37 & -0.04 & 0.06 & 0.37 & 1 & & & \\
(8) Precipitation & 0.16 & -0.21 & 0.35 & 0.06 & -0.50 & -0.14 & -0.34 & 1 & & & \\
(9) Landlockedness & -0.13 & 0.24 & 0.1 & 0.25 & 0.09 & 0.46 & 0.46 & -0.22 & 1 & & \\
(10) Temperature & 0.31 & -0.34 & -0.02 & -0.26 & -0.89 & -0.25 & -0.23 & 0.35 & -0.19 & 1 & \\
(11) \% of pop in tropical zones & 0.23 & -0.39 & 0.22 & -0.20 & -0.74 & -0.21 & -0.16 & 0.76 & -0.25 & 0.62 & 1 \\
\hline
\end{tabular}

Notes: Conflict incidence is the number of five year sub-periods, between 1960 and 2014, that has at least one ongoing conflict of any intensity. Variation in crop yield and mean crop yield are the standard deviation and mean, respectively, of potential (average) crop yield (measured in millions of kilo calories per hectare per year) across different regions in each country. 


\subsection{Empirical Results}

\subsubsection{Cross-country analysis of intrastate conflict}

Table 2-3 presents our findings for the influence of variation in crop yield on conflict incidence in a cross-section of 135 countries. The analysis here makes use of data on the ongoing conflict incidence dimension of civil conflict over the period from 1960 to 2014.

Table 2-3 Main regression results (cross-sectional OLS)

\begin{tabular}{|c|c|c|c|c|}
\hline \multirow[b]{2}{*}{ Dependent variable: } & (1) & (2) & (3) & $\begin{array}{c}(4) \\
\text { (Baseline) }\end{array}$ \\
\hline & \multicolumn{4}{|c|}{ Conflict incidence (confinc) } \\
\hline \multirow[t]{2}{*}{ Variation in crop yield, log } & $0.17^{* * *}$ & $0.20^{* *}$ & $0.34^{* * * *}$ & $0.47^{* * *}$ \\
\hline & $(2.67)$ & $(2.52)$ & $(3.46)$ & $(4.71)$ \\
\hline \multirow[t]{2}{*}{ Mean crop yield, log } & & -0.07 & -0.07 & -0.08 \\
\hline & & $(-1.06)$ & $(-0.71)$ & $(-0.86)$ \\
\hline \multirow[t]{2}{*}{ Rugged terrain, $\%$} & & & 0.04 & -0.02 \\
\hline & & & $(0.35)$ & $(-0.13)$ \\
\hline \multirow[t]{2}{*}{ Absolute Latitude } & & & $0.52^{*}$ & 0.08 \\
\hline & & & (1.79) & $(0.26)$ \\
\hline \multirow[t]{2}{*}{ Elevation } & & & 0.14 & -0.00 \\
\hline & & & $(0.97)$ & $(-0.00)$ \\
\hline \multirow[t]{2}{*}{ Distance to waterways } & & & $0.29^{* *}$ & $0.23^{*}$ \\
\hline & & & $(2.60)$ & $(1.69)$ \\
\hline \multirow[t]{2}{*}{ Precipitation } & & & 0.14 & 0.07 \\
\hline & & & $(0.84)$ & $(0.44)$ \\
\hline \multirow[t]{2}{*}{ Landlockedness } & & & $-0.25^{* * *}$ & $-0.24^{* * *}$ \\
\hline & & & $(-2.78)$ & $(-2.73)$ \\
\hline \multirow[t]{2}{*}{ Temperature } & & & $0.80^{* * * *}$ & $0.57^{* *}$ \\
\hline & & & $(3.10)$ & $(2.14)$ \\
\hline \multirow[t]{2}{*}{$\%$ pop in tropical zones } & & & 0.15 & 0.16 \\
\hline & & & $(0.94)$ & $(1.04)$ \\
\hline Observations & 135 & 135 & 135 & 135 \\
\hline Adjusted R-squared & 0.02 & 0.02 & 0.20 & 0.30 \\
\hline Continent dummies & No & No & No & Yes \\
\hline
\end{tabular}

Notes: This table presents standardized beta coefficients of the influence of variation in crop yield on conflict incidence in reduced-form. The continent dummies are Africa, Asia, Europe, North America, South America, with Oceania as the excluded group. An intercept is included in all the regressions but not reported for brevity. ${ }^{* * *}$ denotes statistical significance at $1 \%$ level, ${ }^{* *}$ at the $5 \%$ level and, ${ }^{*}$ at the $10 \%$ level. Robust t-statistics are given in parentheses 
Column (1) uses no control variable and shows that the unconditional influence of variation in crop yield on conflict incidence is positive and significant at $1 \%$ level. Measured in a standardized form, a one standard deviation change in (logs) variation in crop yield is expected to result in 0.17 standard deviations increase in conflict incidence. We introduce mean crop yield in column (2). The results show that the influence of variation in crop yield on conflict incidence, after accounting for the influence of mean crop yield, remains highly statistically significant. We include standard geographic controls in column (3) and the coefficient of crop yield variation remains statistically significant. Column (4) shows that the results are also robust to the inclusion of continent fixed effects. In all case, we do not find any significant effect of average crop yield.

The partial regression plot in Figure 2-3 shows the relationship between conflict incidence and variation in crop yield. As expected, the partial regression line shows a positive and statistically significant influence of variation in crop yield on conflict incidence, after controlling for other geographical controls and continent fixed effect in column (4) of Table 2-3. 


\section{Figure 2-3 Relationship between conflict incidence and crop yield variation}

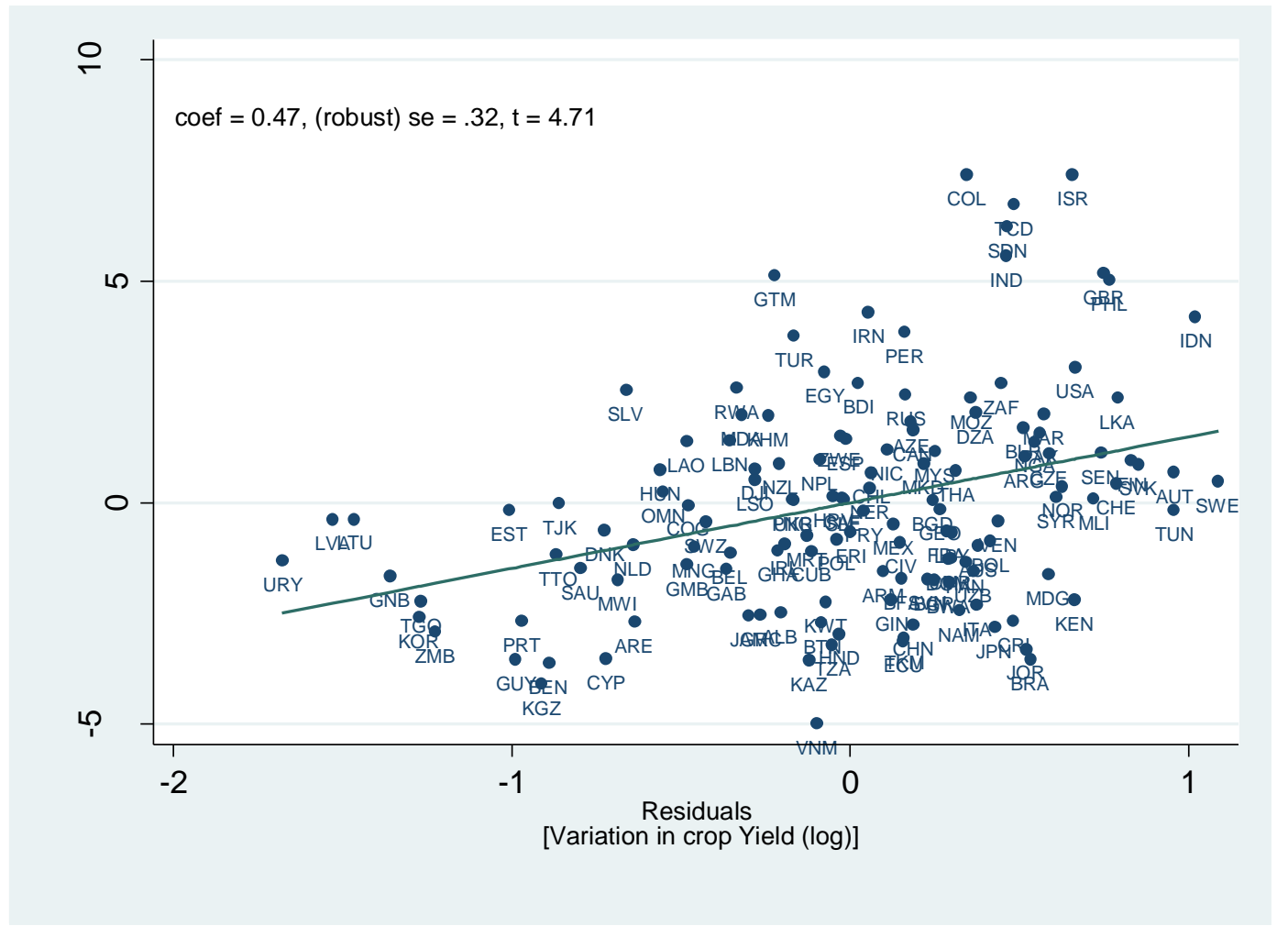

Notes: The partial regression line in diagrams illustrates the influence of variation in crop yield on conflict incidence while partialing out the effects of all other control variables, including mean crop yield, rugged terrain, absolute latitude, elevation, distance to waterways, precipitation, landlockedness, temperature, and fraction of population in tropical zones (see column (4) of Table 2-2). The number of observations is 135 . 
Table 2-4 Robustness to alternative methods and measures of conflict

\begin{tabular}{|c|c|c|c|c|c|c|c|c|c|c|}
\hline & (1) & (2) & (3) & (4) & (5) & (6) & (7) & (8) & (9) & (10) \\
\hline $\begin{array}{l}\text { Dep. Var. = } \\
\text { (estimator) }\end{array}$ & $\begin{array}{l}\text { Confinc } \\
\text { (Poisson) }\end{array}$ & $\begin{array}{c}\text { confinc } \\
\text { (Neg. Binomial) }\end{array}$ & $\begin{array}{c}\text { confinc_mid } \\
\text { (OLS) }\end{array}$ & $\begin{array}{c}\text { confinc_war } \\
\text { (OLS) }\end{array}$ & $\begin{array}{l}\text { onset } 2 \\
(\mathrm{OLS})\end{array}$ & $\begin{array}{l}\text { onset5 } \\
\text { (OLS) }\end{array}$ & $\begin{array}{c}\text { onset_eth } \\
\text { (OLS) }\end{array}$ & $\begin{array}{c}\text { confinc_ns } \\
\text { (OLS) }\end{array}$ & $\begin{array}{c}\text { confict_hist } \\
\text { (OLS) }\end{array}$ & $\begin{array}{c}\text { confinc_frac } \\
\text { (OLS) }\end{array}$ \\
\hline Var in crop yield, log & $\begin{array}{l}0.23^{* * * *} \\
(4.46)\end{array}$ & $\begin{array}{l}0.24^{* * * *} \\
(4.34)\end{array}$ & $\begin{array}{l}0.39^{* * *} \\
(3.28)\end{array}$ & $\begin{array}{l}0.29^{* *} \\
(2.49)\end{array}$ & $\begin{array}{l}0.41^{* * * *} \\
(3.76)\end{array}$ & $\begin{array}{l}0.43^{* * *} \\
(4.14)\end{array}$ & $\begin{array}{l}0.33^{* * * *} \\
(2.90)\end{array}$ & $\begin{array}{l}0.46^{* * *} \\
(4.64)\end{array}$ & $\begin{array}{l}0.24^{* * * *} \\
(2.71)\end{array}$ & $\begin{array}{l}0.46^{* * * *} \\
(4.25)\end{array}$ \\
\hline Mean crop yield,log & $\begin{array}{c}-0.05 \\
(-0.95)\end{array}$ & $\begin{array}{c}-0.07 \\
(-1.14)\end{array}$ & $\begin{array}{c}-0.04 \\
(-0.42)\end{array}$ & $\begin{array}{c}0.05 \\
(0.69)\end{array}$ & $\begin{array}{c}-0.01 \\
(-0.15)\end{array}$ & $\begin{array}{c}-0.06 \\
(-0.58)\end{array}$ & $\begin{array}{c}0.09 \\
(1.05)\end{array}$ & $\begin{array}{c}-0.04 \\
(-0.41)\end{array}$ & $\begin{array}{c}-0.01 \\
(-0.09)\end{array}$ & $\begin{array}{c}-0.08 \\
(-0.91)\end{array}$ \\
\hline Observations & 135 & 135 & 135 & 135 & 135 & 135 & 135 & 131 & 135 & 135 \\
\hline Pseudo / Adjusted R ${ }^{2}$ & 0.28 & 0.12 & 0.16 & 0.09 & 0.22 & 0.22 & 0.19 & 0.25 & 0.10 & 0.23 \\
\hline Baseline controls & Yes & Yes & Yes & Yes & Yes & Yes & Yes & YES & YES & Yes \\
\hline Continent FE & Yes & Yes & Yes & Yes & Yes & Yes & Yes & YES & YES & Yes \\
\hline
\end{tabular}

Notes: Columns (1) to (2) present results using Poisson and negative binomial regression methods, respectively. Pseudo R-squared values are reported for these regressions. least one ongoing conflict of any intensity; confinc_mid is number of five year sub-periods, between 1960 and 2014, that had at least one ongoing conflict where battlerelated deaths were less than one thousand in a single year but cumulative battle-related deaths exceeded one thousand since the beginning of the episode of conflict in any year within a 5-year sub-period; confinc_war is number of five year sub-periods, between 1960 and 2014, that had at least one ongoing conflict where battle-related deaths exceeded one thousand in a single year in any year within the 5-year sub-period; onset 2 and onset 5 are the number of five-year sub-periods, between 1960 and 2014 , that had at least one onset of new conflict episode after two and five years of continuous peace respectively; onset_eth is the aggregate of new ethnic conflicts between 1960 and 2010; confinc_ns are number of five year sub-periods, between 1960 and 2014, that had at least one ongoing non-state conflict respectively; conflict_hist is the total number conflicts during the period 1500-2010; confinc_frac is the fraction of years that had incidence of conflict over period 1960-2014. Adjusted R-squared values are reported for these regressions. Absolute latitude, elevation, distance to sea, average precipitation, average temperature, ruggedness, landlockedness, and \% population in tropical zones are included as additional controls in all regressions. The continent dummies are Africa, Asia, Europe, North America, South America and Oceania. An intercept is included in all the regression but not reported for brevity of space. ${ }^{* * *}$ denotes statistical significance at $1 \%$ level, ${ }^{* *}$ at the $5 \%$ level and, ${ }^{*}$ at the $10 \%$ level. Robust $t$-statistics are given in parentheses. 


\subsubsection{Robustness to the method of estimation}

Our baseline outcome variable measures the intensity of conflict incidence in a country on an 11-point scale. Moreover, given that our dependent variable takes positive integer values with a large number of zero values the data are over dispersed (the variance of 10.32 is much larger than the mean value of 2.54). Consequently, we also perform count data analysis, i.e., Poisson and Negative binomial regressions, as suggested by Cameron and Trivedi (1986) and Wooldridge (2010), to provide a robustness check of our results. Columns (1) and (2) of Table 2-3 report the findings using these alternative estimators, respectively, and indicate that our earlier results prevail.

\subsubsection{Robustness to alternative definitions of conflict}

We have used the number of conflict incidence with at least 25 battle-related deaths within a year as our outcome variable so far. There could be some concerns regarding the way conflict intensity is defined (i.e., the number of 5 -year periods that has at least one conflict over the period 1960-2014). For instance, a country that has experienced only one incidence of conflict in a particular five-year period will be regarded as having the same extent of conflict intensity as another country having experienced conflicts every year over the same period. We address this problem in subsequent section where we use various alternative definitions and data sources to measure conflict intensity.

Accordingly, to ensure that our results are not driven by the way the outcome variable is defined, we also use confinc_mid and confinc_war as alternative measures of conflict incidence, where the former captures medium conflict (less than 1000 battlerelated deaths in a given year but at least cumulative 1000 battle-related deaths since 
the beginning of conflict) and the latter captures major conflict (at least 1000 battlerelated deaths in a given year) respectively, as defined earlier.

The estimation results for using confinc_mid and confinc_war as outcome variables are presented in columns (3) and (4), respectively. The results indicate that the influence of variation in crop yield on medium conflict incidence (column 3) and major conflict incidence (column 4) is statistically highly significant in both cases. Notice that the value of the adjusted $R^{2}$ in column (4) drops substantially. One possible explanation is that the occurrence of major conflicts is likely to be largely determined by idiosyncratic shocks not captured by our model. For this reason, we believe that confinc, the measure of conflict incidence that includes low-intensity conflict with at least 25 but less than 1000 battle-related deaths in a year, is a more appropriate outcome measure for the purpose of our study.

Next, we perform additional robustness checks by using two measures on the onset of new conflicts as our alternative outcome variables. These measures, namely onset 2 and onset5, suffer from the problem that they cannot fully distinguish between new episodes of conflict and ongoing conflict when battle-related deaths exceed the threshold of 25 in a given year. Bearing this limitation in mind, we prefer our baseline approach to focus on the frequency of new conflict. Columns (5) and (6) present the results of estimating the influence of variation in crop yield on the frequency of the onset of new conflict using onset 2 and onset 5 as the dependent variable, respectively. In both cases, the effect of variation in crop yield is still statistically significant at $1 \%$ level.

In column (7), we present the results for regressing the onset of new ethnic conflict on the variation of crop yield. It is evident that the results are qualitatively very similar to what we obtained earlier. The influence of variation in crop yield on the 
incidence of non-state conflicts is tested in column (8). The results again remain largely intact to this alternative outcome measure.

Additionally, we also consider data on the number of internal conflicts from 1500$2000 \mathrm{AD}$ in column (9). The results indicate that the influence of variation in crop yield on conflict over the last five centuries remains consistent. Finally, to mitigate the concern that the intensity of conflicts is smoothed out over a five-year period, we also use the fraction of years that had incidence of conflict over the period 19602014. Our results shown in column (10) are not affected by this consideration.

\subsubsection{Robusness to controlling for the effects of early development}

Our results may also be biased due to the failure to control for some influential early development effects emphasized in the literature. In particular, Ahlerup and Olsson (2012) show that the duration of human settlement since prehistoric time affects the level of ethnolinguistic diversity of current populations. Similarly, Ashraf and Galor (2013) show that the migratory distance from East Africa explains current income levels. Since ethnolinguistic fractionalization and economic development are closely related to conflict, we control for these confounding factors in columns (1) and (2), respectively. Our results reported in Table 2-5 clearly indicate that variation in crop yield remains highly significant. 
Table 2-5 Robustness to controlling for the effects of early development

\begin{tabular}{|c|c|c|c|c|c|c|}
\hline & $(1)$ & $(2)$ & (3) & $(4)$ & $(5)$ & (6) \\
\hline Dependent variable & \multicolumn{6}{|c|}{ Conflict incidence (confinc) } \\
\hline Variation in crop yield, log & $\begin{array}{l}0.42^{* * * *} \\
(4.34)\end{array}$ & $\begin{array}{l}0.47^{* * * *} \\
(4.61)\end{array}$ & $\begin{array}{l}0.39^{* * * *} \\
(3.75)\end{array}$ & $\begin{array}{l}0.46^{* * * *} \\
(4.45)\end{array}$ & $\begin{array}{l}0.37^{* * * *} \\
(3.89)\end{array}$ & $\begin{array}{l}0.46^{\text {*** }} \\
(4.55)\end{array}$ \\
\hline Mean crop yield & $\begin{array}{c}-0.06 \\
(-0.62)\end{array}$ & $\begin{array}{c}-0.07 \\
(-0.71)\end{array}$ & $\begin{array}{c}-0.07 \\
(-0.86)\end{array}$ & $\begin{array}{c}-0.06 \\
(-0.63)\end{array}$ & $\begin{array}{c}-0.08 \\
(-0.96)\end{array}$ & $\begin{array}{c}-0.10 \\
(-0.96)\end{array}$ \\
\hline Origtime & $\begin{array}{c}-0.07 \\
(-0.42)\end{array}$ & & & & & \\
\hline Migratory distance from East Africa & & $\begin{array}{c}-0.41 \\
(-1.04)\end{array}$ & & & & \\
\hline State history up to $1500 \mathrm{AD}$ & & & $\begin{array}{c}0.08 \\
(0.58)\end{array}$ & & & \\
\hline Years since agricultural transition & & & & $\begin{array}{c}0.09 \\
(0.59)\end{array}$ & & \\
\hline Biogeography & & & & & $\begin{array}{c}0.07 \\
(0.46)\end{array}$ & \\
\hline Population density in 1500 AD (log) & & & & & & $\begin{array}{c}0.09 \\
(0.76) \\
\end{array}$ \\
\hline Observations & 128 & 130 & 123 & 126 & 121 & 128 \\
\hline Adjusted R-squared & 0.31 & 0.31 & 0.30 & 0.30 & 0.31 & 0.31 \\
\hline Baseline Controls & Yes & Yes & Yes & Yes & Yes & Yes \\
\hline Continent FE & Yes & Yes & Yes & Yes & Yes & Yes \\
\hline
\end{tabular}

Notes: This table reports standardized beta coefficients using OLS. All regressions include the baseline controls, including absolute latitude, elevation, distance to sea, average precipitation, average temperature, ruggedness, landlockedness, and \% population in tropical zones. The continent dummies are Africa, Asia, Europe, North America, South America and Oceania. An intercept is included in all the regression but not reported for brevity of space. ${ }^{* * *}$ denotes statistical significance at $1 \%$ level, ${ }^{* *}$ at the $5 \%$ level and, ${ }^{*}$ at the $10 \%$ level. Robust t-statistics are given in parenthesis. 
Depetris-Chauvin (2015) shows that areas which have longer state history are less likely to experience conflicts induced by agricultural shocks since the local governments have greater bureaucratic capability. The timing of agricultural transition and biogeography are other dimensions of early development which are closely correlated to agricultural productivity (see Olsson and Hibbs, 2005 and Putterman, 2008 for a discussion). We account for these effects in columns (3) to (5). Lastly, we also control for the effect of early development using a more generic measure - population density in $1500 \mathrm{AD}$ (logged) - in column (6). In all cases, coefficients of these indicators are found to be insignificant whereas the coefficients of variation in crop yield remain very precisely estimated.

\subsubsection{Robustness to the inclusion of additional control variables}

In this sub-section, we conduct some further robustness checks on the results by considering some additional control variables and report these results in Table 2-6. First, we augment the baseline specification by adding executive constraints, democracy, autocracy, oil exports as a fraction of total export, and real GDP per capita. As highlighted by Gurr (2000) and Fearon and Laitin (2003), political systems such as democracy and autocracy are strongly related to conflict. Real GDP per capita acts as a proxy for the opportunity cost of engaging in intrastate conflict whereas oil exports as a fraction of total exports are included to capture the effect of natural resources.

Moreover, we also control for the effects of colonial legacy, following the results of Posner (2003). Controlling for the influence of colonial legacies is important since they may play an important role in stabilizing political institutions in newly independent states, especially given the fact that colonizers arbitrarily defined ethnic 
groups for administrative purposes and sometimes followed ethnically biased policies. Accordingly, we use colonial history dummies for British, French, Spanish, Portuguese and other major European colonizers. However, there may be some residual influence of legal systems originating from European colonizers, with large differences between those originating from English common law and those originating from Roman civil law. Hence, we also use dummy variables for British Common Law, French civil law, Socialist law, German civil law, and Scandinavian law to capture the major categories of legal origins, as suggested by La Porta et al. (1998). As shown in column (1), including these variables does not change our results in any significant fashion. Essentially, the effect of variation of crop yield remains highly significant, suggesting that our results are not driven by these possible omitted influences.

While we control for the effect of colonial origins in column (1), Olsson (2009) emphasizes the importance of the temporal dimension of colonial rule on institutions due to the fact that colonizers needed time to establish institutions. Controlling for this effect in column (2) does not amend our findings. I account for quality of institutions, measured by first principal component of six indicators as used in Kauman. I subdivided the sample into low and high institutions quality (mean = 0.479) and the results for two regressions reported in column (3) and (4), respectively, indicate that the influence of variation in crop yield on conflict after accounting for other baseline control variables remains robust. 
Table 2-6 Robustness to the inclusion of additional covariates

\begin{tabular}{|c|c|c|c|c|c|c|c|c|c|c|}
\hline & (1) & (2) & (3) & (4) & (5) & (6) & (7) & (8) & (9) & (10) \\
\hline Dependent variable & \multicolumn{10}{|c|}{ Conflict incidence (confinc) } \\
\hline Variation in crop yield, log & $\begin{array}{l}0.39^{3 * 2} \\
(4.15)\end{array}$ & $\begin{array}{l}0.33^{n+7} \\
(2.31)\end{array}$ & $\begin{array}{c}0.55^{* * 6} \\
(3.98)\end{array}$ & $\begin{array}{l}0.566^{* 7} \\
(2.37)\end{array}$ & $\begin{array}{c}0.47^{* * 9} \\
(4.77)\end{array}$ & 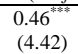 & $\begin{array}{l}0.40^{* * *} \\
(3.91)\end{array}$ & $\begin{array}{l}0.41^{* * *} \\
(3.87)\end{array}$ & $\begin{array}{l}.42^{3 * *} \\
(4.04)\end{array}$ & $\begin{array}{l}0.48^{2 * n+1} \\
(4.20)\end{array}$ \\
\hline Mean crop yield, log & $\begin{array}{c}-0.12 \\
(-1.05)\end{array}$ & $\begin{array}{c}-0.15 \\
(-1.07)\end{array}$ & $\begin{array}{c}-0.23 \\
(-1.37)\end{array}$ & $\begin{array}{c}-0.04 \\
(-0.20)\end{array}$ & $\begin{array}{c}-0.09 \\
(-0.87)\end{array}$ & $\begin{array}{c}-0.07 \\
(-0.64)\end{array}$ & $\begin{array}{c}-0.16 \\
(-1.54)\end{array}$ & $\begin{array}{c}-0.08 \\
(-0.83)\end{array}$ & $\begin{array}{c}-0.03 \\
(-0.26)\end{array}$ & $\begin{array}{c}-0.11 \\
(-0.80)\end{array}$ \\
\hline Executive control & $\begin{array}{c}0.34 \\
(1.48)\end{array}$ & & & & & & & & & \\
\hline Autocracy & $\begin{array}{c}-0.11 \\
(-0.58)\end{array}$ & & & & & & & & & \\
\hline Democracy & $\begin{array}{c}-0.21 \\
(-1.07)\end{array}$ & & & & & & & & & \\
\hline$\%$ Oil export in total export & $\begin{array}{c}0.06 \\
(0.71)\end{array}$ & & & & & & & & & \\
\hline GDP per capita, log & $\begin{array}{l}-0.31^{* *} \\
(-2.52)\end{array}$ & & & & & & & & & \\
\hline Colonial history ( $F$-statistic) & $\begin{array}{c}1.98 \\
{[p=0.102]}\end{array}$ & & & & & & & & & \\
\hline Legal origin ( $F$-statistic) & $\begin{array}{c}1.98 \\
{[p=0.103]}\end{array}$ & & & & & & & & & \\
\hline Duration of colonial experience & & $\begin{array}{c}0.19 \\
(1.55)\end{array}$ & & & & & & & & \\
\hline Ethnic fractionalization (Fearon, 2003) & & & & & $\begin{array}{l}0.10 \\
(1.05)\end{array}$ & & & & & \\
\hline $\begin{array}{l}\text { Religion fractionalization (Alesina et. al., } \\
\text { 2003) }\end{array}$ & & & & & & -0.06 & & & & \\
\hline Fractionalization (Estaben, 2012) & & & & & & $(-0.67)$ & $\begin{array}{c}0.14 \\
(1.26)\end{array}$ & & & \\
\hline Polarization (Estaben, 2012) & & & & & & & $\begin{array}{l}0.24^{* *} \\
(2.27)\end{array}$ & & & \\
\hline Greenberg Gini index (Estaben, 2012) & & & & & & & $\begin{array}{c}-0.27^{* * *} \\
(-3.56)\end{array}$ & & & \\
\hline Mountainous terrain & & & & & & & & $\begin{array}{c}0.22 \\
(1.33)\end{array}$ & & \\
\hline Non-contiguous & & & & & & & & $\begin{array}{l}0.22^{* *} \\
(2.24)\end{array}$ & & \\
\hline Disease richness & & & & & & & & & $\begin{array}{c}-0.05 \\
(-0.24)\end{array}$ & \\
\hline Variation in elevation & & & & & & & & & & $\begin{array}{c}0.01 \\
(0.07)\end{array}$ \\
\hline Mean land quality (soil-based) & & & & & & & & & & $\begin{array}{c}0.03 \\
(0.29) \\
\end{array}$ \\
\hline Observations & 135 & 75 & 76 & 59 & 135 & 133 & 118 & 135 & 124 & 130 \\
\hline Adjusted R-squared & 0.34 & 0.36 & 0.25 & 0.11 & 0.30 & 0.29 & 0.39 & 0.33 & 0.31 & 0.29 \\
\hline Baseline Controls & Yes & Yes & Yes & Yes & Yes & Yes & Yes & Yes & Yes & Yes \\
\hline Continent FE & Yes & Yes & Yes & Yes & Yes & Yes & Yes & Yes & Yes & Yes \\
\hline
\end{tabular}

Notes: This table reports standardized beta coefficients using OLS. All regressions include the baseline controls, including absolute latitude, elevation, distance to sea, average precipitation, average temperature, ruggedness, landlockedness, and \% population in tropical zones. The continent dummies are Africa, Asia, Europe, North America, South America and Oceania. An intercept is included in all the regression but not reported for brevity of space. ${ }^{* *}$ denotes statistical significance at $1 \%$ level, ${ }^{* *}$ at the $5 \%$ level and, ${ }^{*}$ at the $10 \%$ level. Unless stated otherwise, robust $t$ statistics are given in parentheses. The colonial history dummies are Spanish, British, French, and Portuguese. The legal origin dummies are British Common Law, French civil law, Socialist law, German civil law, and Scandinavian law.

Next, we control for several diversity measures which have been shown to influence some development outcomes in the existing literature. These variables are the ethnic fractionalization index of Fearon (2003) (column (5)), the religion fractionalization index of Alesina et al. (2003) (column (6)), and the fractionalization, polarization and Greenberg Gini indices of Esteban et al. (2012) (column (7)). Our results are largely unaffected.

Furthermore, Fearon and Laitin (2003) find that the mountainous terrain and noncontiguous region at a distance from the center of political power provides a safe 
haven for rebel groups and it facilitates the emergence and perpetuation of civil war. Finally, Letendre et al. (2010) find that the "disease richness" of a country can provide potential ground for higher levels of conflict. The higher "disease richness" (the total number of different types of infectious diseases in a country) of a country can increase its mortality rate and therefore reduce the opportunity cost for individuals to indulge in a civil war (Cervellati et al., 2011). Controlling for these effects in columns (8) and (9), respectively, does not alter our main findings.

Finally, a recent study by Michalopoulos (2012) highlights that diversity in a society may originate from some geographical features of the region. He shows that geographical features, such as variation in elevation and soil quality, can explain ethnolinguistic diversity. We control for these additional geographic features in column (10) but do not find them to be correlated with conflict.

\subsubsection{Robustness to elimination of regions from estimation sample}

We also investigate whether our results - specifically, with respect to the influence of variability in crop yield on conflict incidence - are driven by the inclusion of a particular region in our sample. We drop the observations belonging to a particular continent sequentially and re-estimate our baseline model. The results after dropping one continent at a time are presented in Table 2-7. The estimates indicate that the influence of variability in crop yield is found to be statistically significant at least at 5\% level in all cases. Hence, we conclude that our results are not sensitive to the exclusion of observations from any particular continent. 
Table 2-7 Robustness to the elimination of regions

\begin{tabular}{lccccc}
\hline \multirow{2}{*}{ Dependent variable } & $(1)$ & $(2)$ & $(3)$ & $(4)$ & $(5)$ \\
\cline { 2 - 6 } & & & \multicolumn{2}{l}{ Conflict incidence (confinc) } \\
\hline Variation in crop yield, log & $0.40^{* * * *}$ & $0.28^{* * *}$ & $0.56^{* * * *}$ & $0.49^{* * * *}$ & $(4.60)$ \\
Mean crop yield & $(3.35)$ & $(2.36)$ & $(4.24)$ & $(4.82)$ & -0.07 \\
& 0.03 & -0.13 & -0.12 & -0.11 & $(-0.69)$ \\
\hline Continent FE & $(0.26)$ & $(-1.28)$ & $(-0.83)$ & $(-1.06)$ & Yes \\
Baseline controls & Yes & Yes & Yes & Yes & Yes \\
\hline Omitted Continent & Yes & Yes & Yes & Yes & South America \\
Observations & Africa & Asia & Europe & North America & 124 \\
Adjusted $R^{2}$ & 94 & 99 & 104 & 0.34 & 0.32 \\
\hline
\end{tabular}

Notes: This table reports standardized beta coefficients using OLS. All regressions include the baseline controls, including absolute latitude, elevation, distance to sea, average precipitation, average temperature, ruggedness, landlockedness, and \% population in tropical zones. The continent dummies are Africa, Asia, Europe, North America, South America and Oceania. An intercept is included in all the regression but not reported for brevity of space. ${ }^{* * *}$ denotes statistical significance at $1 \%$ level, ${ }^{* *}$ at the $5 \%$ level and, ${ }^{*}$ at the $10 \%$ level. Robust $t$-statistics are given in parenthesis.

\subsection{Further Analyses Using Repeated Cross-country Data}

In this section, we exploit the time dimension of conflict incidence using quinquennial repeated cross-country data. A similar regression framework is used except that our outcome variable is now a binary variable measuring the potential for an active conflict episode in country $i$ during any given 5-year period. We also account for intertemporal spillover effect of conflict incidence on contemporary conflict incidence by including a lagged dependent variable in our regression model. Table 2-7 gives the regression results. Column (1) reports results for the unconditional influence of variation in crop yield on conflict incidence. The effect is found to be statistically significant at $1 \%$ level. We account for time-invariant geographical control variables in column (2) and further control for continent effects in column (3). Column (4) assesses the influence of variation in crop yield on conflict 
incidence, conditional on time-invariant geographic effects and time-varying institutional and output variables. In all cases, the effect of crop yield variation remains very precisely estimated at $1 \%$ level.

The various outcome variables that we have employed so far reflect the extensive margin effect of variation in crop yield on intrastate conflict events as they use binary measure depending on a threshold number of the battle-related deaths in a year. Hence, we also employ both ordinal and continuous measures of conflict incidence that capture the severity of intrastate conflict to establish the influence of variation in crop yield on the intensive margin of conflict.

The first measure of conflict of intensity that we employ is a non-binary measure of conflict intensity, confinc_int, which is based on UCDP arms conflict dataset. Following Esteban et al. (2012), we categorize confinc_int into three distinct intensity level $-0,1$, and 2 in any year. When a country is at "Peace", confinc_int is assigned a zero value, conflict incidence satisfying confinc but not confinc_war is assigned a value of 1 whereas conflict incidence satisfying confinc_war criteria are assigned a value of 2 . 
Table 2-8 Repeated cross-country results

\begin{tabular}{|c|c|c|c|c|}
\hline \multirow[b]{2}{*}{ Dependent variable } & $(1)$ & $(2)$ & (3) & (4) \\
\hline & \multicolumn{4}{|c|}{ Conflict incidence (confinc) } \\
\hline Variation in crop yield, log & $\begin{array}{l}0.68^{* * * *} \\
(2.86)\end{array}$ & $\begin{array}{l}1.08^{* * * *} \\
(2.90)\end{array}$ & $\begin{array}{l}1.47^{* * * *} \\
(3.86)\end{array}$ & $\begin{array}{l}1.46^{* * *} \\
(3.81)\end{array}$ \\
\hline Mean crop yield, log & $\begin{array}{l}-0.39^{* * *} \\
(-1.98)\end{array}$ & $\begin{array}{l}-0.40 \\
(-1.12)\end{array}$ & $\begin{array}{l}-0.54 \\
(-1.43)\end{array}$ & $\begin{array}{c}-0.64 \\
(-1.63)\end{array}$ \\
\hline Rugged terrain, $\%$ & & $\begin{array}{c}0.48 \\
(1.26)\end{array}$ & $\begin{array}{c}0.46 \\
(1.14)\end{array}$ & $\begin{array}{l}0.65^{*} \\
(1.73)\end{array}$ \\
\hline Absolute Latitude & & $\begin{array}{c}1.17 \\
(1.42)\end{array}$ & $\begin{array}{c}0.53 \\
(0.58)\end{array}$ & $\begin{array}{c}0.06 \\
(0.07)\end{array}$ \\
\hline Elevation & & $\begin{array}{c}0.42 \\
(0.96)\end{array}$ & $\begin{array}{c}0.04 \\
(0.08)\end{array}$ & $\begin{array}{l}-0.99^{*} \\
(-1.81)\end{array}$ \\
\hline Distance to waterways & & $\begin{array}{l}1.27^{* * * *} \\
(3.58)\end{array}$ & $\begin{array}{l}1.12^{* * * *} \\
(2.83)\end{array}$ & $\begin{array}{l}0.90^{* *} \\
(1.96)\end{array}$ \\
\hline Precipitation & & $\begin{array}{c}0.20 \\
(0.48)\end{array}$ & $\begin{array}{c}0.16 \\
(0.35)\end{array}$ & $\begin{array}{c}-0.08 \\
(-0.16)\end{array}$ \\
\hline Landlockedness & & $\begin{array}{l}-1.01^{\text {**** }} \\
(-3.00)\end{array}$ & $\begin{array}{l}-0.94^{* * * *} \\
(-2.71)\end{array}$ & $\begin{array}{l}-0.70^{*} \\
(-1.85)\end{array}$ \\
\hline Temperature & & $\begin{array}{l}2.28^{* * * *} \\
(3.18)\end{array}$ & $\begin{array}{l}1.80^{* * *} \\
(2.14)\end{array}$ & $\begin{array}{c}0.51 \\
(0.59)\end{array}$ \\
\hline$\%$ pop in tropical zones & & $\begin{array}{c}0.53 \\
(0.98)\end{array}$ & $\begin{array}{c}0.68 \\
(1.34)\end{array}$ & $\begin{array}{c}0.41 \\
(0.71)\end{array}$ \\
\hline Executive control & & & & $\begin{array}{c}0.54 \\
(1.03)\end{array}$ \\
\hline Autocracy & & & & $\begin{array}{l}-0.72^{* *} \\
(-2.30)\end{array}$ \\
\hline Democracy & & & & $\begin{array}{l}-1.07^{* * *} \\
(-2.68)\end{array}$ \\
\hline Oil & & & & $\begin{array}{c}0.21 \\
(0.90)\end{array}$ \\
\hline GDP per capita, log & & & & $\begin{array}{l}-0.75^{*} \\
(-1.82)\end{array}$ \\
\hline Conflict incidence, lagged & $\begin{array}{l}3.01^{* * * *} \\
(14.57)\end{array}$ & $\begin{array}{l}2.71^{* * * *} \\
(13.26)\end{array}$ & $\begin{array}{l}2.56^{* * * *} \\
(12.61)\end{array}$ & $\begin{array}{l}2.40^{* * * *} \\
(11.82)\end{array}$ \\
\hline Continent FE & No & No & Yes & Yes \\
\hline Colonial history FE & No & No & No & Yes \\
\hline Legal origin FE & No & No & No & Yes \\
\hline Observations & 1157 & 1157 & 1157 & 1117 \\
\hline pseudo $R^{2}$ & 0.31 & 0.34 & 0.36 & 0.37 \\
\hline
\end{tabular}

Notes: This table reports standardized beta coefficients using OLS. All regressions include the baseline controls, including absolute latitude, elevation, distance to sea, average precipitation, average temperature, ruggedness, landlockedness, and \% population in tropical zones. The continent dummies are Africa, Asia, Europe, North America, South America and Oceania. An intercept is included in all the regression but not reported for brevity of space. ${ }^{* * *}$ denotes statistical significance at $1 \%$ level, ${ }^{* *}$ at the $5 \%$ level and, ${ }^{*}$ at the $10 \%$ level. Unless stated otherwise, robust $z$-statistics are given in parentheses. The colonial history dummies are Spanish, British, French, and Portuguese. The legal origin dummies are British Common Law, French civil law, Socialist law, German civil law, and Scandinavian law. 
Our second measure of conflict intensity is based on the Major Episodes of Political Violence (MEPV), 1946-2014 dataset (Marshall, 2014). Major episodes of conflicts, according to this database, involve "at least 500 directly-related fatalities and reach a level of intensity in which political violence is both systematic and sustained (a base rate of 100 directly-related deaths per annum)". For each episode of conflict, the MEPV dataset provides the "magnitude score" of the destructive impact, or magnitude of the violent episode of the directly-affected areas on a scale of 1 (smallest) to 10 (greatest). We employ data on the total intrastate conflict that includes civil violence, civil conflict, ethnic violence and ethnic war. This data are reported at the country-year level and to convert them into quinquennial intervals, we create our outcome variable by using the maximum level of conflict intensity from any year in each of the 5-year periods.

Our third measure of the intensity of conflict is a continuous index of social conflict (ISC) computed by Cross-National Time-Series (CNTS) Data Archive (Banks, 2011). The data are taken from Esteban et al., 2012. The period of this conflict severity is limited to between 1960 and 2008, or only ten sub-periods of the 5-year interval (we used eleven sub-periods of 5-year interval earlier). The results in Table 2-9 show that the influence of variation in crop yield on conflict is still statistically significant even when these alternative measures of conflict are used. 
Table 2-9 Repeated cross-sectional results for conflict incidence severity

\begin{tabular}{lccc}
\hline \multirow{2}{*}{ Dependent variable } & $(1)$ & $(2)$ & $(3)$ \\
\cline { 2 - 4 } & confinc_int & $\begin{array}{c}\text { Major Episodes of } \\
\text { Political Violence (MEPV) }\end{array}$ & $\begin{array}{c}\text { index of social conflict } \\
\text { (ISC) }\end{array}$ \\
\hline Variation in crop yield, log & $1.02^{\text {*****}}$ & $0.24^{* * *}$ & $0.11^{* * * *}$ \\
Mean crop yield, log & $(3.92)$ & $(3.13)$ & $(3.22)$ \\
& -0.24 & -0.06 & 0.02 \\
Conflict intensity, lagged & $(-0.89)$ & $(-0.66)$ & $(0.64)$ \\
Baseline controls & Yes & Yes & Yes \\
Continent FE & Yes & Yes & Yes \\
Observations & Yes & Yes & 1,035 \\
(pseudo) $R^{2}$ & 1,451 & 1,278 & 0.39
\end{tabular}

Notes: This table presents standardized coefficients using ordered logit estimation in column (1) and (2), and OLS in column (3). This table reports standardized beta coefficients using OLS. All regressions include the baseline controls, including absolute latitude, elevation, distance to sea, average precipitation, average temperature, ruggedness, landlockedness, and \% population in tropical zones. The continent dummies are Africa, Asia, Europe, North America, South America and Oceania. An intercept is included in all the regression but not reported for brevity of space. ${ }^{* * *}$ denotes statistical significance at $1 \%$ level, ${ }^{* *}$ at the $5 \%$ level and, ${ }^{*}$ at the $10 \%$ level. Robust $z$-statistics are given in parentheses.

\subsection{Analysis Using Grid-level Data}

In this section, we provide further evidence using data at the grid level. The analysis is performed using a global grid of 2.5 by 2.5 decimal degrees covering from -180 to 180 degrees longitude and from -65 to 85 degrees latitude. To create our outcome variable, we use the latest version (version 5) of UCDP Georeferenced Event Dataset (Sundberg and Melander, 2013). This dataset provides global conflict events (excluding Syria) over the period 1989-2015. A conflict event is defined as: "An incident where armed force was by an organised actor against another organized actor, or against civilians, resulting in at least 1 direct death at a specific location and a specific date”. The reporting unit is an individual event and the dataset contains 128,264 events. Figure 4 shows the distribution of conflict across grid cells. 
Figure 2-4 Conflict data for grid cells of 2.5 by 2.5 decimal degrees

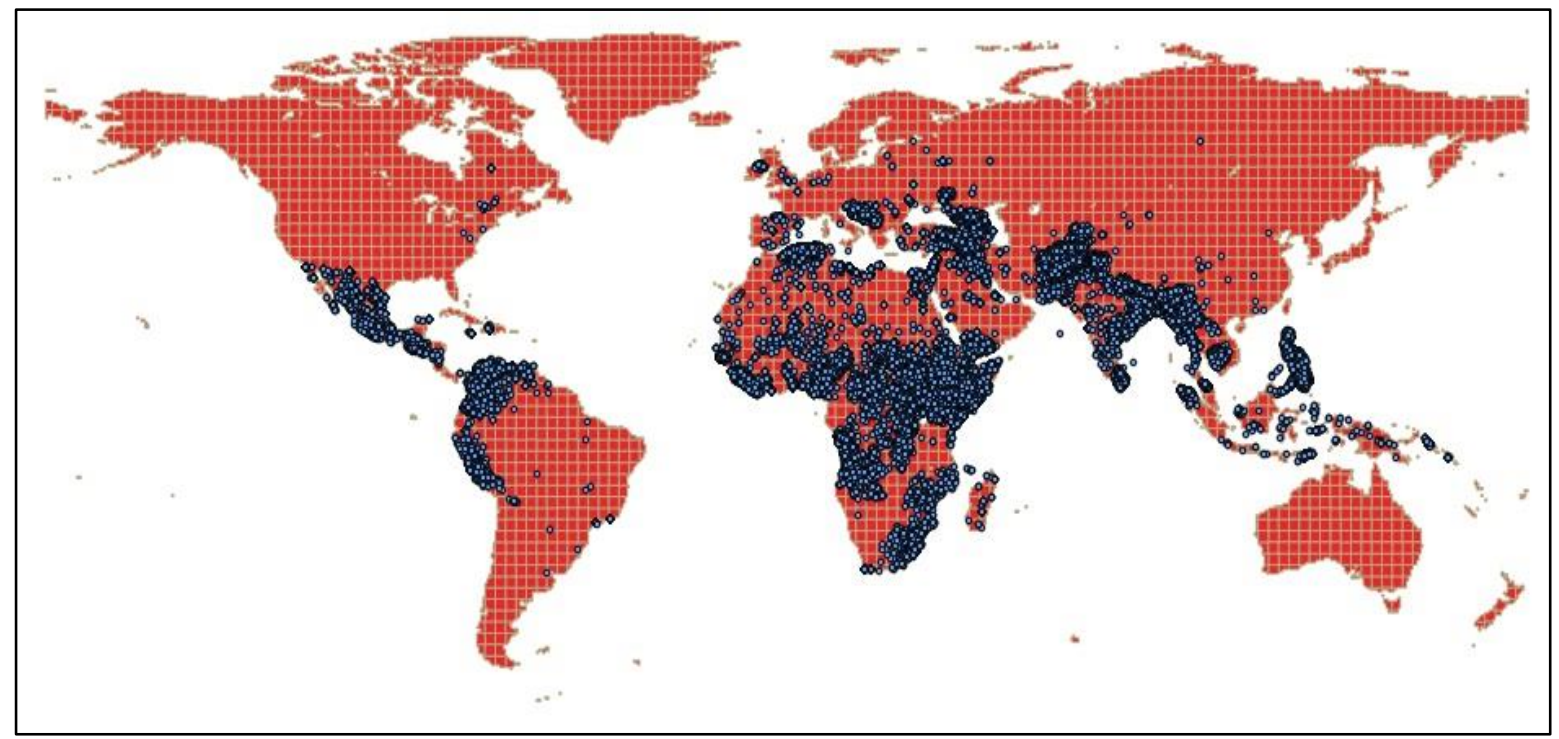

Notes: Longitude extends from -180 to 180 degree, and latitude extends from -65 to 85 degree. Dots represent individual conflict events during the period 1989-2015. The Conflict events data are taken from Sundberg and Melander (2013).

It should be highlighted that this dataset is compatible with the one used earlier for cross-sectional analysis. Only conflict events involving at least 25 casualties are reported. The best spatial resolution for the conflict events of this dataset is individual village or town. Three type of events - state based, non-state, and one sided - are reported in the dataset.

As in previous sections, we focus on state-based events where one party in the conflict is the state. This reduces the number of conflict events in the dataset to 89,943. We match these violent events, using latitude and longitude of the events, with our grid of 2.5 by 2.5 decimal to identify corresponding grid cells for each event over period 1989-2015. Two outcome variables are then created. The first variable indicates weather there was an incidence of conflict in a given grid cell (labeled as 
"presence of conflict incidence"). The second is constructed using an approach similar to that of confinc. We divide the whole period 1989-2015 into six 5-year subperiods (the last sub-period covers only 2 years). We indicate conflict intensity as 1 if there is at least one event of conflict in that grid cell in the 5-year window and 0 otherwise. The aggregate number is our second measure and we label it as "frequency of conflict incidence". The grid-level geographical data are obtained from Michalopoulos (2012).

Table 2-10 Grid-level analysis

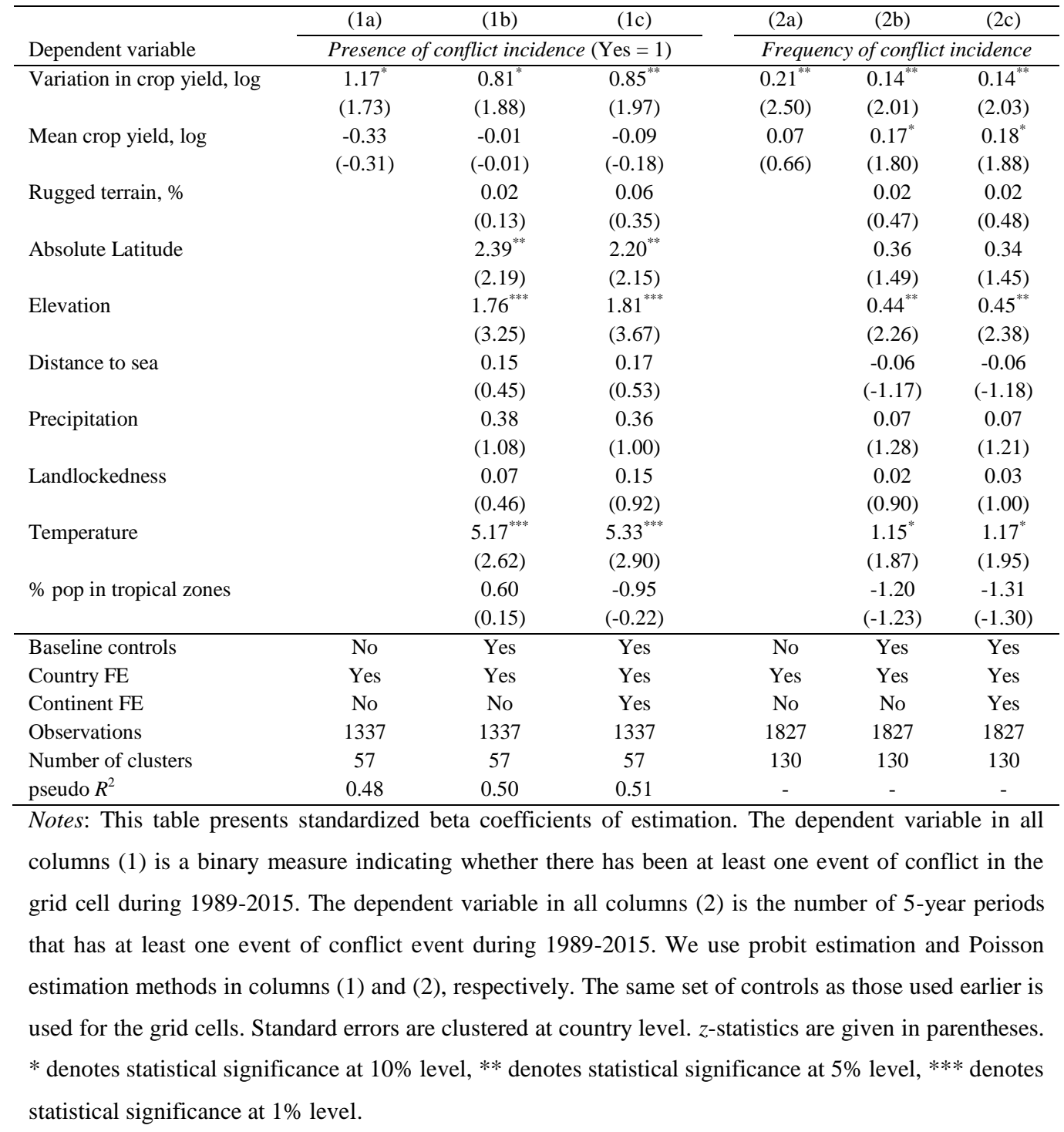


The results for using grid-level data are reported in Table 2-9. As is evident, variation in crop yield is found to have a significant effect on conflict, regardless of which outcome measure is used and whether control variables and continent fixed effects are included.

\subsection{Conclusions}

Agroecology in general, and geography and climate in particular, has become an important topic of research in economics as part of a broader agenda to understand the origin of both intrastate and interstate conflict. Nevertheless, there is ambiguity in identifying the specific aspects of geography and climate that have significant influence over the likelihood of conflict incidence. Recent studies indicate that available resources in a region and the opportunity cost of the people to participate in violence play a key role in the onset and persistence of conflict incidence.

This study contributes to this growing literature by identifying the role of crop yield (measured in millions of kilocalories per hectare per year) variation as an important source of conflict. Most of the conflicts were initiated to achieve dominance of power over people from another ethnicity, religion, race or gender in order to control lands with high crop yield potential. There can be various plausible mediating channels to explain this relationship. As different groups settle in different parts of a country, their economic prosperity should be positively influenced by the agricultural productivity in that region. Consequently, a country with higher variation in crop yield is expected to have higher ethnic inequality, and this in turn induces more conflicts. Similarly, the formation of cultures of aggression and violence is also likely to occur when societies depend on agriculture for survival. Although, many societies are not as dependent on farming today as they were a few centuries ago the culture of 
violent behavior developed centuries ago may transmit from across generations. As this violent behavior continues to persist, one should expect to observe more intrastate conflict in a country that has higher variation in crop yield across regions. Our empirical findings provide support for this hypothesis. Specifically, we found a variation in crop yield to have a significant effect on conflict incidence. These findings are supported by the use of alternative outcome variables, measures of conflict, the inclusion of a number of possible confounders, and alternative empirical regression methods. The results are also consistent when grid cell level data are used. There is possibility of extending the work for interstate conflict between countries. A variable can be constructed to indicate pairwise difference between the potential crop yield of countries. This variable may be able to explain much of interstate conflict as variance in crop yield within a country explained intrastate conflicts in this chapter. However, this will require a careful consideration of understanding which interstate conflicts to examine. Many interstate conflicts may occur among the neighboring countries but other interstate conflicts might occur between countries not necessarily adjoining geographically. Also, one needs to look at how to construct the independent variable - whether to look at the difference of the mean of crop yield of countries or at the difference of the mean of the crop yield at border areas with some buffer across the borders. 


\section{DATA APPENDIX}

\section{A. Conflict measures (outcome variables)}

Confinc: This variable takes value one when there is at least one ongoing conflict of any intensity, as reported in Armed Conflict Dataset, version 4-2015 (Pettersson and Wallensteen, 2015), in any year within a 5-year sub-period; otherwise it is zero. We use the sum of this variable across 11 sub-periods in cross-section study. Confinc_mid: This variable takes value one when there is at least one ongoing conflict episode having battle-related deaths of less one thousand in a single year but having cumulative battle-related deaths exceeding one thousand since the beginning of the conflict episode, as reported in Armed Conflict Dataset, version 4-2015 (Pettersson and Wallensteen, 2015), in any year within a 5-year sub-period; otherwise it is zero. We use the sum of this variable across 11 sub-periods in the cross-section study.

Confinc_war: This variable takes value one when there is at least one ongoing conflict episode having battle-related deaths exceeding one thousand in a single year, as reported in Armed Conflict Dataset, version 4-2015 (Pettersson and Wallensteen, 2015), in any year within a 5-year sub-period; otherwise it is zero. We use the sum of this variable across 11 sub-periods in the cross-section study.

Onset 2 and onset5: These variables take value one when a new conflict episode starts, as reported in Conflict Onset and Incidence Dataset (Pettersson and Wallensteen, 2015), after two and five years of 'peace', respectively, in any year within a 5-year sub-period; otherwise it is zero. We use the aggregate value of these variables across 11 sub-periods in the cross-section study.

onset_eth: This variable takes value one when a new conflict, that has an ethnic 
origin, starts in any year; otherwise it is zero. We use the aggregate value of this variable over the period of study. We construct this variable using updated data from Wimmer et al. (2009).

Confinc_ns: This variable is constructed similar to confinc defined above, but, unlike the above, no side in the conflict is government or state forces. This variable is constructed using non-state conflict dataset ${ }^{6}$, Version 2.5-2014, 1989-2013 (source: Sundberg et al., 2012).

Confinc_int: This variable indicates the intensity of conflict on a scale of zero to three. When a country is at "Peace", confinc_int is assigned a zero value, conflict incidence satisfying confinc but not confinc_war is assigned a value of 1 whereas conflict incidence satisfying confinc_war criteria are assigned a value of 2 .

Major Episodes of Political Violence (MEPV): This variable indicates the intensity of conflict on a scale of one (smallest) to ten (highest). We use a maximum of this variable in any year within a 5-year sub-period based on Major Episodes of Political Violence, 1946-2014 dataset (source: Marshall, 2014).

Index of Social Conflict (ISC): This variable indicates the intensity of conflict as computed by Cross-National Time-Series Data Archive for the period from 1960 to 2008 (source: Esteban et al., 2012).

\section{B. Crop yield variation (main explanatory variable)}

This index captures variation in potential crop yield (measured in millions of

\footnotetext{
${ }^{6}$ For example, between paramilitary United Self-Defense Forces of Colombia (AUC) and the guerrilla Revolutionary Armed Forces of Colombia (FARC) in Colombia, or between the competing rebel groups National Patriotic Front of Liberia (NPFL) and United Liberation Movement of Liberia for Democracy (ULIMO) in Liberia ; clashes between supporters of the All Nigeria People's Party and supporters of the People's Democratic Party in Nigeria; between groups that define themselves along identity lines, be it ethnic, clan, religious, national, or tribal identities. Fighting between these types of groups captures what is commonly referred to as communal conflict, such as Hindu-Muslim riots in India.
} 
kilocalories per hectare per year) across different regions in a country. Crop yield index is constructed using crop yield (measured in tons per hectare per year) from Global Agro-Ecological Zones (GAEZ) project of Food and Agriculture Organization (FAO) and caloric content of various crops from US Department of Agriculture Nutrient Database for Standard Reference (source: Galor and Özak, 2016).

\section{Baseline geographic controls}

Ruggedness. The calculation for ruggedness takes a point on the earth's surface and measures the difference in elevation between this point and each of the eight major directions of the compass (north, northeast, east, southeast, south, southwest, west, and northwest). The index at the central point is given by the square root of the sum of the squared differences in elevation between the central point and the eight adjacent points (source: Nunn and Puga, 2012).

Latitude. The absolute value of latitude of a country's centroid, as reported on http://gothos.info/resources.

Elevation. The average elevation of a country, in thousands of kilometers above sea level, calculated using geospatial data at a 1-degree resolution from the Geographically based Economic data (G-ECON) project.

Distance to waterways. The distance, in thousands of km, from a GIS grid cell to the nearest ice-free coastline or sea-navigable river, averaged across the grid cells of a country (source: Harvard University's CID Research Datasets on General Measures of Geography).

Precipitation. The average precipitation of a country, in a unit of 10 millimeters per month over the period from 1961-1990, calculated using geospatial data at a 1-degree resolution from the Goegraphically based Economic data (G-ECON) project. 
Landlockedness. This dummy variable indicates whether a country is landlocked or not (source: Global Development Network Growth Database).

Temperature. The average temperature of a country, in a unit of 10 degree Celsius per month over the period from 1961-1990, calculated using geospatial data at a 1-degree resolution from the Geographically based Economic data (G-ECON) project.

$\%$ of population living in tropical zones. The percentage of a country's population in 1995 that resided in areas classified as tropical by the Koppen-Geiger climate classification system (source: Harvard University's CID Research Datasets on General Measures of Geography).

\section{Other controls}

Origtime. The historical duration of human settlement (in million years) (source: Ahlerup and Olsson, 2012).

Migratory distance from East Africa. The 'Haversine' distance from Addis Ababa to a particular country's modern capital city along a land-restricted route forced through at least one of the five stopping points, including Cairo, Istanbul, Phnom Penh, Anadyr, and Prince Rupert. The variables are rescaled so that a higher value indicates greater proximity (source: Ashraf and Galor, 2013).

State history up to $1500 \mathrm{AD}$. An index of state history covering the period from $1 \mathrm{AD}$ to $1500 \mathrm{AD}$, scaled to take values between 0 and 1 . The dataset was originally introduced by Bockstette et al. (2002), but the current paper uses its latest version, v3.1. (source: Putterman, 2012)._ENREF_38).

Years since agricultural transition. The number of years elapsed, in 2000 AD, since the transition to agriculture was estimated to occur (in thousand years) (source: Putterman, 2006). 
Biogeography. The first principal component of the standardized numbers of domesticable wild plants and animals (source: Hibbs and Olsson, 2004; Olsson and Hibbs, 2005).

Population density in $1500 \mathrm{AD}(\log )$. The population in $1500 \mathrm{AD}$ divided by land area (source: McEvedy and Jones, 1978; World Development Indicators, 2012).

Autocracy. An index from the Polity IV project that reflects the degree of institutionalized autocracy. The variable is measured on a scale of 0 to 10 , where 10 indicates the largest degree of autocracy (source: Marshall et al., 2012).

Democracy. An index from the Polity IV project that reflects the degree of institutionalized democracy. The variable is measured on a scale of 0 to 10 , where 10 indicates the largest degree of democracy (source: Marshall et al., 2015).

Executive constraints. An index from the Polity IV project that reflects the degree of constraints on executives. The variable is measured on a scale of 1 to 7 , where 7 indicates the largest amount of constraints (source: Marshall et al., 2015).

Oil. A dummy variable indicating whether the proportion of export revenues from oil is larger than 1/3 (Fearon and Laitin, 2003).

GDP per capita. GDP per capita data at constant price (2005 US\$) (source: World Bank Development Indicators 2015).

Colonial history. A classification of a country's colonial origin into British, French, Portuguese, Spanish, or other European (i.e., Dutch, Belgian, and Italian) since 1700. For countries ruled by several colonial powers, the most recent one is taken provided that it was ruled for ten years or longer (source: Nunn and Puga, 2012).

Legal origins. A classification of a country's legal tradition into British common law, French civil law, German civil law, Scandinavian law or Socialist law (source: La Porta et al., 1998). 
Duration of colonial history: This is measured as time spent under colonial rule in hundreds of years, i.e. year of independence minus year of colonization, divided by 100 (source: Olsson, 2009).

Ethnic fractionalization. This is defined as the probability that two randomly selected individuals in a country will be from different ethnic groups (source: Fearon, 2003). Religion fractionalization: This variable is computed as one minus Herfindahl index of religious group shares. It reflects the probability that two randomly selected individuals from population belongs to different religion groups (source: Alesina et al., 2003).

Disease richness. A standardized index of historical pathogen prevalence for nine diseases, including leishmanias, schistosomes, trypanosomes, leprosy, malaria, typhus, filariae, dengue, and tuberculosis (source: Murray and Schaller, 2010).

Fractionalization. This index is constructed as: $\mathrm{F}=\sum_{i=1}^{m} n_{i}\left(1-n_{i}\right)$, where $n_{i}$ is the population share of group $i$ and $m$ is the number of groups (source: Esteban et al., 2012).

Polarization. This index is constructed as: $\sum_{i=1}^{m} \sum_{j=1}^{m} n_{i}^{2} n_{j} k_{i j}$, where $k_{i j}=1-s_{i j}^{0.5}$ and $s_{i j}$ is the degree of similarity between two languages, $i$ and $j$, given the ratio of the number of common branches to the maximum possible number of 15 for the entire tree. $n_{i}$ is the population share of group $i$ and $m$ is the number of groups (source: Esteban et al., 2012).

Greenberg Gini index. This index is constructed as: $G=\sum_{i=1}^{m} \sum_{j=1}^{m} n_{i} n_{j} k_{i j}$, where $k_{i j}=1-s_{i j}^{0.5}$ and $s_{i j}$ is the degree of similarity between two languages, $i$ and $j$, given by the ratio of the number of common branches to the maximum possible 
number of 15 for the entire tree. $n_{i}$ is the population share of group $i$ and $m$ is the number of groups (source: Esteban et al., 2012).

Mountainous terrain. Proportion area of a country that is mountainous (source: Fearon and Laitin, 2003).

Non-contiguous. Noncontiguous states refer to countries with territory holding of at least 10,000 people and are separated from the land area containing the capital city either by land or by 100 kilometers of water (source: Fearon and Laitin, 2003).

Variation in elevation: This measure indicates standard deviation of elevation within country (source: Michalopoulos, 2012).

Mean land quality (soil-based): This measure presents average agricultural suitability of land across regions based on soil properties (source: Michalopoulos, 2012). 


\section{Soil Quality and Colonization}

\subsection{Introduction}

Adam Smith considered that the discovery of America and the passage to the East Indies by the rounding of the Cape of Good Hope were "the two greatest and most important events in recorded history of mankind.” (1776, p. 626). Both events occurred in the 1490s and opened sea routes from Europe to the unknown West and East. The unintentional consequence of the explorers' activities was the later colonization by Europeans of a large part of the world along these sea routes. A consensus has emerged that colonial legacies play an important role in contemporary economic and political development (see, for example, North (1990), Hall and Jones (1999), Sokoloff and Engerman (2000), Acemoglu, Johnson and Robinson (2001); Acemoglu, Johnson and Robinson (2002)). However, our understanding of why some areas were colonized earlier and for a longer time period than others remains limited. The determinants of the timing of colonization, including factor endowments and geography, have not received sufficient attention despite the fact that this may have affected subsequent economic, political, and institutional development.

During a colonial history spanning almost five centuries, advances in maritime technology (including the shift from sailing to the steam engine and the development of the longitude clock), European industrial development, and the European enlightenment were some of the important events that influenced the pace and characteristics of colonization. While European sailors knew sea routes to Africa since the $14^{\text {th }}$ century (more than a century before they set foot in the Americas), there was no major colonization in Africa until the 'Scramble for Africa' conference took place in Berlin in 1884-1885. Meanwhile, Spanish sailors established colonies in 
Americas within a few years of their discovery, and were subsequently followed by other Europeans.

In general, the economic opportunities offered by under-developed and underdefended areas were the main attractions for the European colonizers. ${ }^{7}$ Many Western European nations were competing for claims on natural resources and other advantages through the establishment of permanent settlements and the pursuit of expeditions and companies engaged in international trade. ${ }^{8}$ European emigrants were willing to make risky journeys to an unknown world in order to share in its spoils. The economic returns on large-scale plantations were so large that despite the high costs of traversing the Atlantic, millions of African slaves were bought and transported to the Americas to work as laborers in agricultural activities. ${ }^{9}$

The central questions addressed in this paper are: $(i)$ what determined the timing of the colonization of an area?; (ii) what determined the duration of an area's colonization? We seek to identify the factors that played key roles in determining the timing and duration of colonization of various territories. In particular, we focus on the role of agricultural productivity.

In Europe in the $15^{\text {th }}-18^{\text {th }}$ centuries, there were natural constraints on further economic growth, with limited resources available before the Industrial Revolution

\footnotetext{
${ }^{7}$ Other factors were the chance discovery and colonization of many islands because they were near important trade routes or the winds took the sailors to these locations.

${ }^{8}$ The Dutch East India Company and the English East India Company were set up during seventeenth century to exploit trading opportunities in the East.

${ }^{9}$ The British plantation economy was so profitable that on the eve of the American revolution, the wealth generated from Jamaica was comparable to the wealth produced in a large English county such as Lancashire or Sussex (Higman (2005); Burnard (2001)).
} 
shaped the future. ${ }^{10}$ Population growth appears to have overtaken the capacity of farming to feed much of Western Europe, and the growing number of people living in tumultuous and insalubrious cities were prone to riots (Bayly (2004: p 93)). By some estimates, the European population increased from 30 millions in 1000 AD to 74 millions in $1340 \mathrm{AD}^{11}$ (Livi-Bacci (2012)). With the discovery of the Americas, vast quantities of relatively unpopulated land became available to the Western Europeans. The land was used for large plantations of sugar and other commodities, which were highly valued in Europe. Crosby (1989) emphasizes the importance of the Columbian exchange across the Atlantic, noting that: "The coming together of the continents was a prerequisite for the population explosion of the past two centuries, and certainly played an important role in the Industrial Revolution. The transfer across the ocean of the staple food crops of the Old and New Worlds made possible the former" (page 666). Crops such as sugar, coffee, soybeans, oranges, and bananas from the New World were all introduced to the Old World, and the Americas quickly started supplying vast quantity of these crops globally.

Europe was predominantly an agricultural society in late $15^{\text {th }}$ and the $16^{\text {th }}$ centuries and land played a key role in society. Since the European colonizers came from predominantly agricultural societies, agriculture was naturally seen an important economic activity. Moreover, any long-term settlers would have to be largely selfsufficient in terms of food production and timber, as it would be costly and uncertain

\footnotetext{
${ }^{10}$ Emphasizing the important role of land, Adam Smith argued that the growth of every species happens in proportion to the means of their subsistence, and that species can never multiply beyond their means.

${ }^{11}$ A more appropriate estimate of population would be from $1500 \mathrm{AD}$ when the Western Europeans started colonization. However, population was almost stagnant for over 100 years because of the high mortality rate caused by the Black Death in Europe.
} 
(particularly considering the food shortages in Europe) to transport supplies from elsewhere. Productive agricultural activities and the construction of housing would have to commence almost immediately in order for settlers to survive the sometimes harsh winters (and perhaps a hostile native population). This consideration appears particularly crucial early on in the colonization process, when food imports were not available from, for example, other nearby earlier-colonized areas with (potential) surpluses. For example, the historian de Herrera y Tordesillas (1601-1615) reports that during Columbus' second voyage to Hispaniola (in present-day Dominican Republic) in 1493 , hunger and disease led to mutiny by his men, which led to punishment, disillusion, and more hunger and disease. The honorable Gentleman Master George Percy, who was onboard one of three ships chartered by King James I that sailed with 144 men and boys in December 1606 to establish a colony in presentday Virginia, wrote in June-July 1607 that the area had a fruitful soil, with abundant trees (mulberry, cherry, walnut, cedar, sassafras, and cypress trees, as well as vines); however, by August-September 1607 the men were suffering from a lack of fresh water, and dying of diseases, from conflicts with the native population, and most of all from famine (Percy (1608)).

Based on the discussion above, we argue that agricultural productivity, both in the short- and long-run, was a main determinant of the decision to colonize an area. Thus, greater land productivity should have influenced the timing of an area's colonization in a positive fashion. Moreover, land productivity should also have affected the duration of an area's colonization, as an uncertain supply should of have made an area less attractive to hold onto. Our measure of land productivity is potential average crop yield, constructed by Galor and Özak (2016). To our knowledge, this is the first paper that studies the association between the timing and duration of post-1500 
European colonization and the productivity of agriculture across non-European territories around the world. ${ }^{12}$

Our cross-country analysis provides robust evidence that a greater average crop yield was associated with an earlier and more durable colonization. The results survive a number of robustness checks, including tests for unobserved omitted variable bias, the exclusion of colonizers from the sample, inclusion of early development indicators, and controlling for several geographical and ecological conditions. Moreover, we find consistent estimates when we redo the analysis at the grid-cell level, which helps mitigate any endogeneity concerns that may arise with the crosscountry estimations.

The present paper contributes to the emerging literature that seeks to identify the deep roots of contemporary economic development. In particular, this study makes a contribution to the field of study focusing on the long-term influence of important historic events, in this case the colonization activities of multiple European nations. Ertan, Fiszbein and Putterman (2016) study the timing of colonization, in particular

\footnotetext{
12 The term colonization is quite broad, as earlier expansions by empires may be categorized as colonization. We focus on the post-1500 colonization by the Western European powers of the rest of the world. Earlier imperial expansions such as the Roman and Ottoman empires, and the expansion by Imperial Japan in Asia in the early twentieth century, are thus excluded. We make no distinction between settler colonization (or direct administration, or direct rule, mainly in the New World) and exploitative colonization (indirect administration, mainly in the Old World). Settler colonies were established in either unpopulated or thinly populated territories, and involved large numbers of emigrants from western or central Europe. These emigrants created institutions and cultures based on their experience from their motherlands. The geographical factors identified to play key roles in the determination of the location of settler colonies include malaria ecology and disease rates (Acemoglu, Johnson and Robinson (2001)), and climate similar to Europe (Crosby (1986: p 6)). Exploitative colonialism involved a small number of colonists, whose main objective was to profit from the colony's resources and to exploit indigenous labor.
} 
the effects of the timing of the agricultural transition (Neolithic revolution), statehood experience (state antiquity), and technological development. While we agree that these are plausible determinants of the timing (and duration) of colonization, we argue that other factors appear to have been relatively more fundamental. In particular, we propose that agricultural productivity was a crucial consideration by the colonizers. In addition, we contribute to the literature by using grid-cell level data, which enables us to take advantage of within-country variation.

The previous literature studying contemporary effects of the interactions between Europe and the rest of the world includes one branch that explores the colonizers' influence abroad, e.g. on the institutions left behind (e.g., Engerman and Sokoloff (1997); La Porta, Silanes et al. (1998); and Acemoglu, Johnson and Robinson (2001)). A second branch studies the impact of the discovery of the New World on Europe. Acemoglu, Johnson and Robinson (2005) argue that profits from the threecorner Atlantic trade strengthened the merchant class, which resulted in stronger probusiness institutions and increased economic growth in Europe. Moreover, the introduction of potatoes to the Old World strongly influenced the population growth and urbanization rate in Europe (Mokyr (1981); Nunn and Qian (2011)).

We recognize that the exploitation of agricultural opportunities was not the sole objective behind early colonists' exploration of sea routes through the Atlantic and the rounding of the Cape of Good Hope. Trade (controlled by traders and protected by the Crown) and religion (controlled by the Church) were interlinked motivations. Traders were looking for an alternative route to India to bring spices at low cost to Europe. ${ }^{13}$ Evangelists wanted to spread Christianity to new territories. In the early

\footnotetext{
${ }^{13}$ It was a disappointment when Christopher Columbus returned from his first journey to the Americas (believed to be India) without any spices. However, subsequent Spanish settlers brought gold and
} 
period of the Spanish empire, the Catholic Church worked to protect the colonial interests of the Spanish empire. However, we argue that the economic profits from agricultural activities played a major role in when and how long colonization occurred.

The rest of the paper is organized as follows. The next section gives background on agriculture - tea, sugar, and timber, in particularly - in former colonies. Section 3 outlines our model specification, and discusses the main variables used in the analysis. Section 4 discusses the findings of our cross-section study and presents various sensitivity tests. Section 5 presents our findings for our grid-cell level analysis, and the last section concludes our findings.

\subsection{Background: Agriculture in the Colonies}

Before the advent of European colonies, most sedentary civilizations were built on the cultivation of a complex carbohydrate, such as maize, potatoes, rice, millet, or wheat (Mintz (1985): p.9). In order to emphasize the role of agricultural productivity in the decision of colonization, we next discuss the importance of three key agricultural crops that were transported from the colonies to Europe: sugar, tea, and timber. These were important sources of much-needed calories for Europe. First, historical evidence suggests that the consumption of sugar played an important role as a source of calories for the European masses (Burbank and Cooper (2010): p. 178). It

silver from the Americas, which led to excess supply of precious metals. This resulted in a prolonged period of high inflation in Western Europe that is also known as The Price Revolution (e.g. Hamilton (1934)). Others suggest that the main cause of The Price Revolution was not the excess supply of money in terms of gold and silver, but rather increasing population and low productivity of agriculture in Europe (e.g. Gould (1964)). A large majority of Europeans lived very close to starvation, as the population expansion appears to have outstripped the growth of agricultural production. 
was likely not coincidental that the early colonies established in the Caribbean and Brazil enjoyed climate and soil conditions that were well-suited for the cultivation of crops such as sugar that were in high demand in the Old World. Sugar (imported from Caribbean islands and the Americas) mixed with tea (imported from China and India) and other hot drinks became a cheap and easy source of calories for a growing urban working class in England (Burbank and Cooper (2010): p. 178). ${ }^{14}$

Large and organized agricultural production in the colonies indirectly supported the industrial revolution and that became the engine of European growth in the nineteenth century. Mintz (1985: p.180) argues that sugar helped create an industrial working class in the United Kingdom, suggesting that sugar "by provisioning, sating - and, indeed drugging - farm and factory workers, sharply reduced the overall cost of creating and reproducing the metropolitan proletariat."

Second, consumption of tea in England increased exponentially during the eighteenth and nineteenth centuries. Customs records (i.e., legal imports) show that England received twenty thousand pounds of green tea in year 1700 , increasing to five million pounds in year 1760, and twenty million pounds in 1800 . Moreover, large amounts of tea entered England illegally to avoid high taxes. According to the government estimates, in 1766 the illegally imported quantity of tea entering England was at least

\footnotetext{
${ }^{14}$ While sugar does not provide protein, it offered calories in the absence of meat (Hersh and Voth (2009)). For the poor, a cup of sugary tea could reduce the feeling of hunger, provide energy for a short time, and substitute for a hot meal when the price of heating fuel was high (Mintz (1985)). The per capita consumption of sugar increased by 20 -fold from 1663 to 1775, and a further five-fold increase occurred between 1835 and 1935 (Nunn and Qian (2010)). By 1900, sugar was providing almost 20 percent of the calorie intake of the average Englishman (Mintz (1985)). Hersh and Voth (2009) estimate that the increase in sugar availability between the years 1600 and 1850 increased English welfare by eight percent.
} 
as large as the legal quantity. ${ }^{15}$ Cooper (1860) succinctly highlights the importance of trade for the availability of tea and sugar in The Sea Lions; Or, The Lost Sealers. The novel's heroine, Mary Pratt, criticizes the idea of trade: "Ah! why cannot men be content with the blessings that Providence places within our immediate reach, that they must make distant voyages to accumulate others!" (p. 285) The deacon responds: "You like your tea, Mary Pratt - and the sugar in it, and your silks and ribbons that I've seen you wear; how are you to get such matters if there's to be no going on v'y'ges? Tea and sugar, and silks and satins don't grow along with the clams on 'Yster Pond" (p. 285) ${ }^{16}$. Mary changes the subject.

Third, timber from large and dense forests in the colonies was important for the Europeans. Before England's first energy crisis in sixteenth century, it was believed that the supply of wood from native forests was sufficient. However, with increasing economic prosperity and population growth, demand for wood - required to build houses, to keep homes warm, and to build ships - increased continuously. The energy crisis pushed up the price of wood and forced people to use coal. However, they were neither enthusiastic to use a 'dirty source' of energy, nor were they equipped to use coal properly (Nef (1977)).

Ship building was an important use of timber. The scarcity of native forests in England limited the supply of timber for ship building, which severely affected the

\footnotetext{
${ }^{15}$ It appears natural that British entrepreneurs and the government envisioned substantial profits if they established their own tea plantations in the colonies. A tea commission was appointed under the leadership of Lord Bentinck. Within three generations of the commission's report, British entrepreneurs had clear-cut two million acres of forest in India and invested 36 million pounds for tea plantation across 788,842 acres. Over 432 million pounds of green tea were produced for English consumption in this colonial plantation. The Indian tea plantation created huge private wealth and massive tax returns for the British government (Mintz (1985: p.113)).

${ }^{16}$ The deacon uniformly pronounces the word 'oyster' as 'yster.'
} 
performance of the English naval forces in several important wars - three AngloDutch wars, the American Revolution, and contests with Napoleon (Albion (1926)). Before the discovery of the New World, the Baltic countries were the main source of timber. However the supply was prone to be cut off by hostile naval powers. Napoleon's influence excluded England from practically every port in Europe that could furnish masts and ship timber. However, since England had access to the sea, and the forests beyond the sea, timber could be provided from the two Americas, Asia, Africa, and the South Seas. The English Navy appears to have sustained its long struggle with the Napoleonic Empire due to the uninterrupted supply of Canadian pines and oaks. It was subsequently discovered that Indian teak was superior for ship building. ${ }^{17}$

Agricultural produce and final product created a triangular trading market between the colonizers and the colonized. The discovery of the Americas opened opportunities for the English population to consume cheap foods such as fish and dried fruits, as well as luxury drinks (e.g. wine) from the Americas (previously imported from France and the Mediterranean). Tobacco was an American product that gained popularity in Europe. In the later stages of colonization, the colonies provided new markets for English products such as cloth manufactured in mills. The colonies were also helpful in tackling the unemployment problems resulting from changes in agrarian organization (Harrison and Parry (1968)). The poor went as laborers or small farm holders to the New World.

\footnotetext{
${ }^{17}$ Consequently, foreign shipbuilding facilities opened in India, producing ships that played key roles in the English expeditions to Ceylon, Java, Manila, the Moluccas, and the Red Sea between 1795 and 1800 (Albion (1926)).
} 


\subsection{Empirical Approach and Data}

\subsubsection{Regression Model}

We estimate the following regression model to evaluate the influence of crop yield on the timing of colonization:

$$
\operatorname{col}_{i}=\alpha+\beta \text { cropyield }_{i}+\gamma \text { controls }_{i}+\epsilon_{i}
$$

where $\mathrm{col}_{i}$ is years since colonization or the duration of colonization for geographical entity $i$ (where $i$ represents a country or a grid-cell), cropyield cro $_{i}$ is thean of potential (average) crop yield in $i$, and controls $s_{i}$ is a vector of control variables included in the regression model to account for the possible influence of other geographical features on the timing of colonization. We hypothesize that a geographical entity with higher crop yield potential should face a greater likelihood of early colonization, and a longer period of colonization, by Europeans. Thus, $\beta$ should be positive and statistically significant. Our baseline sample in cross-country analysis has data for up to 85 countries.

\subsubsection{Data}

\section{A. Outcome measures}

Years since colonization. The first dependent variable is the number of years elapsed, in $2000 \mathrm{AD}$, since colonization by Europeans was estimated to occur. Identifying a single date for colonialism is difficult for several reasons. The initiation process of colonization was in many countries a gradual and informal process. For example, in the case of America, European settlers reached the New World and started settlements. Gradually, the populations of these settlements increased to hundreds of thousands of Europeans. There are other cases, such as India, where for all practical 
purposes the colony was under the control of the British East India Company after the battle of Plassey in 1757. However, it came under the direct control of the British crown as a colony only in 1858 . To overcome such challenges, Ertan, Fiszbein and Putterman (2016) use quantitative and objective criteria to identify the timing of colonization by Western Europe for 92 countries. According to their criteria, "the process of colonization is considered to have started in a country when $20 \%$ or more of a country's territory was largely under the control of the colonizing power, provided that the majority of the territory would eventually be controlled by the same colonizer or another succeeding colonizer" (p.170).

As a robustness check, we also use data on the timing of colonization by Olsson (2009), who provides the date of colonization, date of independence, and a colonizing event for 143 former colonies that are currently independent countries. ${ }^{18}$ Olsson (2009) identifies the date of colonization according to whether the Western colonizers became the major political power in the region concerned. However, his definition differs from the criteria used by Ertan, Fiszbein, and Putterman (2016). Olsson defines a Western colony as "a new and lasting political organization created outside Europe by Western countries....from the 15 th to the 20th centuries through either invasion and conquest, and/or settlement colonization. Its rulers are in sustained dependence on a geographically remote mother country or imperial center that claims exclusive rights of possession of the colony or in other ways strongly dominates politics in the country."

Duration of colonization. Our second outcome variable is the number of years that a country was under colonial rule. This is constructed by taking the difference between

\footnotetext{
${ }^{18}$ A colonizing event refers to an historical event, battle or treaty between the colonizers and the natives that significantly tilted the power and control in favor of the colonialists.
} 
the year of independence and the year of colonization identified by Olsson (2009). In the robustness checks, we use the year of independence from Olsson (2009) but the year of colonization from Ertan, Fiszbein and Putterman (2016) as an alternative measure for the duration of colonization.

\section{B. Main explanatory variable (Potential (average) crop yield)}

As discussed above, our main independent variable is potential average crop yield. This index captures potential crop yield (measured in millions of kilocalories per hectare per year) across different regions in each country. It addresses the limitations of available weight-based agricultural yield indices. For example, the land productivity index constructed by Ramankutty, Foley et al. (2002) does not capture the fact that equally suitable land may have a large variation in crop yield. Caloricintensive crops may not be cultivated in some regions (see Galor and Özak (2015)). The data on crop yield are taken from Galor and Özak (2016), who construct their dataset from the Global Agro-Ecological Zones (GAEZ) project of the Food and Agriculture Organization (FAO). GAEZ supplies global yield and growth cycle estimates for 48 crops in grids with cells size of 5'x5' (approximately $\left.100 \mathrm{~km}^{2}\right){ }^{19}$ GAEZ supplies crop yield estimates for each crop based on three alternative levels of input - high, medium and low - and two feasible sources of water supply - rain-fed water supply and irrigation. The FAO dataset supplies potential yield estimates for each crop in each agro-climatic grid while accounting for the effect of temperature

\footnotetext{
19 These 48 crops are alfalfa, banana, barley, buckwheat, cabbage, cacao, carrot, cassava, chickpea, citrus, coconut, coffee, cotton, cowpea, dry pea, flax, foxtail millet, green gram, groundnuts, indigo rice, maize, oat, oil palm, olive, onion, palm heart, pearl millet, phaseolus bean, pigeon pea, rye, sorghum, soybean, sunflower, sweet potato, tea, tomato, wetland rice, wheat, spring wheat, winter wheat, white potato, yams, giant yams, subtropical sorghum, tropical highland sorghum, tropical lowland, sorghum, white yams.
} 
and moisture on the growth of the crop.

The crop yield index is constructed using a low level of inputs and rain-fed agriculture cultivation methods in order to account for the agricultural conditions that existed during the pre-industrial era. This reflects farming practices prevalent during the early stages of development. Furthermore, the crop yield data are based on agroclimatic conditions that are independent of any human intervention. This therefore mitigates any potential endogeneity pertaining to agricultural inputs, irrigation method, and soil quality.

Each crop yield in the GAEZ data (measured in tons per hectare per year) is converted by Galor and Özak (2016) into caloric yield (millions of kilocalories per hectare per year) to represent the nutritional variation across crops and to compare crop yields. The US Department of Agriculture Nutrient Database for Standard Reference provides data on the caloric content of various crops. Using these measures, the estimated average regional crop yield reflects the average regional levels of two variables - crop yield and crop cycle - among crops that indicate the average caloric yield in each cell. Our analysis focuses on the averages across cells where the maximum potential crop yield is positive as the survival of humans is not possible in regions with zero caloric yields ${ }^{20}$. We take the mean of the potential average crop yield for all the grids in a country and use it as our measure of potential average crop yield.

\section{Control variables}

Some standard geographic influences which may potentially confound the relationship between potential crop yield and the timing and duration of colonization

\footnotetext{
${ }^{20}$ Our results hold even if we do not exclude these cells.
} 
are included in the regressions. They include terrain ruggedness, absolute latitude, elevation (mean and standard deviation), navigational distance from Europe to the colony (or nearest port), distance to nearest waterway, and landlockedness. The summary statistics and the correlations of the variables are given in Table 3-1.

\subsection{Empirical Results}

\subsubsection{Cross-country Analysis}

Columns (1a)-(1d) of Table 3-2 present our findings using a cross-section of 85 countries. Column (1a) includes no control variables, while column (1b) adds absolute latitude, and column (1c) in addition controls for mean elevation, variation in elevation, ruggedness, and landlockedness. The influence of average crop yield on the timing of colonization is positive and significant at the $1 \%$ level in all three models. Finally, the effect of geographic distance, measured via sea routes and land routes, respectively, is controlled for in column (1d), following Ertan, Fiszbein and Putterman (2016). Our main finding remains intact. The estimate in column (1d) suggests that a one standard deviation (i.e. 944 units) increase in the average crop yield resulted in a territory's colonization occurring 90 years earlier, equivalent to 0.6 standard deviations.

This confirms our hypothesis that the European colonizers prioritized control of territories with high agriculture productivity. Only two control variables exhibit significant coefficients: mean elevation has a negative effect but increased variation a positive effect on the speed of colonization. 
Table 3-1 Summary statistics and correlations

\begin{tabular}{|c|c|c|c|c|c|c|c|c|c|}
\hline \multicolumn{10}{|c|}{ Panel A: Summary statistics } \\
\hline & Obs & Mean & \multicolumn{3}{|c|}{ Standard deviation } & Minimum & \multicolumn{3}{|c|}{ Maximum } \\
\hline Years since colonization (in 100s) & 85 & 2.2 & \multicolumn{2}{|c|}{1.5} & & 0.6 & \multicolumn{3}{|c|}{4.9} \\
\hline Average crop yield & 85 & 1375 & \multicolumn{2}{|c|}{944} & & 7 & \multicolumn{3}{|c|}{4478} \\
\hline Absolute Latitude & 85 & 17.2 & \multicolumn{2}{|c|}{11.1} & & 0.2 & \multicolumn{3}{|c|}{43.7} \\
\hline Mean elevation & 85 & 0.5 & \multicolumn{2}{|c|}{0.4} & & 0.0 & \multicolumn{3}{|c|}{1.7} \\
\hline Variation in elevation & 85 & 0.4 & \multicolumn{2}{|c|}{0.3} & & 0.0 & \multicolumn{3}{|c|}{1.6} \\
\hline Ruggedness & 85 & 1.1 & \multicolumn{2}{|c|}{1.0} & & 0.1 & \multicolumn{3}{|c|}{6.2} \\
\hline Landlockedness & 85 & 0.2 & \multicolumn{2}{|c|}{0.4} & & 0.0 & \multicolumn{3}{|c|}{1.0} \\
\hline Navigational distance & 85 & 5.8 & \multicolumn{2}{|c|}{3.2} & & 1.0 & \multicolumn{3}{|c|}{13.0} \\
\hline Distance to coast & 85 & 0.1 & \multicolumn{2}{|c|}{0.2} & & 0.0 & \multicolumn{3}{|c|}{0.9} \\
\hline \multicolumn{10}{|c|}{ Panel B: Correlations } \\
\hline & $(1)$ & $(2)$ & (3) & (4) & $(5)$ & (6) & (7) & $(8)$ & $(9)$ \\
\hline (1) Years since colonization & 1 & & & & & & & & \\
\hline (2) Mean crop yield & 0.65 & 1 & & & & & & & \\
\hline (3) Absolute Latitude & 0.00 & -0.13 & 1 & & & & & & \\
\hline (4) Mean elevation & -0.1 & -0.11 & 0.00 & 1 & & & & & \\
\hline (5) Variation in elevation & 0.42 & 0.05 & 0.13 & 0.47 & 1 & & & & \\
\hline (6) Ruggedness & 0.08 & 0.13 & 0.23 & 0.52 & 0.31 & 1 & & & \\
\hline (7) Landlockedness & -0.24 & -0.02 & -0.13 & 0.45 & -0.14 & 0.13 & 1 & & \\
\hline (8) Navigational distance & -0.07 & -0.05 & -0.07 & 0.18 & 0.23 & 0.22 & 0.10 & 1 & \\
\hline (9) Distance to coast & -0.27 & -0.12 & -0.22 & 0.37 & -0.22 & -0.02 & 0.72 & 0.00 & 1 \\
\hline
\end{tabular}

Notes: This table presents summary statistics and correlations of variables used in baseline estimation.

Number of observations are 85.

The partial regression plot in Figure 1 shows the relationship between the timing of colonization and average crop yield. The partial regression line displays a positive and statistically significant influence of average crop yield on the timing of colonization, after accounting for the geographic controls included in column (1d) of

Table 3-2. 
Table 3-2 Potential crop yield and colonization

\begin{tabular}{|c|c|c|c|c|c|c|c|c|}
\hline \multirow[b]{2}{*}{ Dependent variable } & (1a) & (1b) & (1c) & (1d) & $(2 a)$ & (2b) & $(2 \mathrm{c})$ & $(2 d)$ \\
\hline & \multicolumn{4}{|c|}{ Timing of colonization } & \multicolumn{4}{|c|}{ Duration of colonization } \\
\hline \multirow[t]{2}{*}{ Average crop yield } & $0.65^{* * * *}$ & $0.67^{\text {***k* }}$ & $0.61^{* * * * *}$ & $0.60^{* * * *}$ & $0.62^{* * * *}$ & $0.62^{* * *}$ & $0.57^{* * * * *}$ & $0.56^{* * * *}$ \\
\hline & $(6.94)$ & $(6.56)$ & $(6.31)$ & $(6.29)$ & $(5.00)$ & (4.77) & $(4.34)$ & $(4.23)$ \\
\hline \multirow[t]{2}{*}{ Absolute Latitude } & & 0.09 & 0.02 & 0.01 & & 0.04 & -0.05 & -0.06 \\
\hline & & $(0.92)$ & $(0.20)$ & $(0.06)$ & & $(0.34)$ & $(-0.49)$ & $(-0.57)$ \\
\hline \multirow[t]{2}{*}{ Mean elevation } & & & $-0.22^{* * *}$ & $-0.26^{* *}$ & & & -0.16 & -0.18 \\
\hline & & & $(-2.00)$ & $(-2.37)$ & & & $(-1.25)$ & $(-1.41)$ \\
\hline \multirow[t]{2}{*}{ Variation in elevation } & & & $0.49^{* * * *}$ & $0.53^{* * * *}$ & & & $0.39^{* * * *}$ & $0.41^{* * * *}$ \\
\hline & & & $(5.07)$ & (5.69) & & & (3.95) & $(4.12)$ \\
\hline \multirow[t]{2}{*}{ Ruggedness } & & & -0.03 & 0.01 & & & 0.01 & 0.04 \\
\hline & & & $(-0.32)$ & $(0.07)$ & & & $(0.10)$ & $(0.38)$ \\
\hline \multirow[t]{2}{*}{ Landlockedness } & & & -0.06 & -0.08 & & & $-0.14^{*}$ & $-0.15^{*}$ \\
\hline & & & $(-0.90)$ & $(-0.99)$ & & & $(-1.91)$ & $(-1.72)$ \\
\hline \multirow[t]{2}{*}{ Navigation distance } & & & & -0.11 & & & & -0.08 \\
\hline & & & & $(-1.32)$ & & & & $(-0.80)$ \\
\hline \multirow[t]{2}{*}{ Distance to coast } & & & & 0.07 & & & & 0.03 \\
\hline & & & & $(0.90)$ & & & & $(0.37)$ \\
\hline $\operatorname{adj} . R^{2}$ & 0.42 & 0.42 & 0.61 & 0.61 & 0.37 & 0.36 & 0.51 & 0.50 \\
\hline Observations & 85 & 85 & 85 & 85 & 79 & 79 & 79 & 79 \\
\hline
\end{tabular}

Notes: This table presents standardized beta coefficients. The dependent variable in the first four columns is the colonization timing whereas the next four columns use the duration of colonization as the outcome variable. The constant term is not reported for brevity. $t$ statistics are given in parentheses; *, **, and $* * *$ represent statistical significance at $10 \%, 5 \%$, and $1 \%$ level.

Figure 3-1 The association between colonization timing and average crop yield

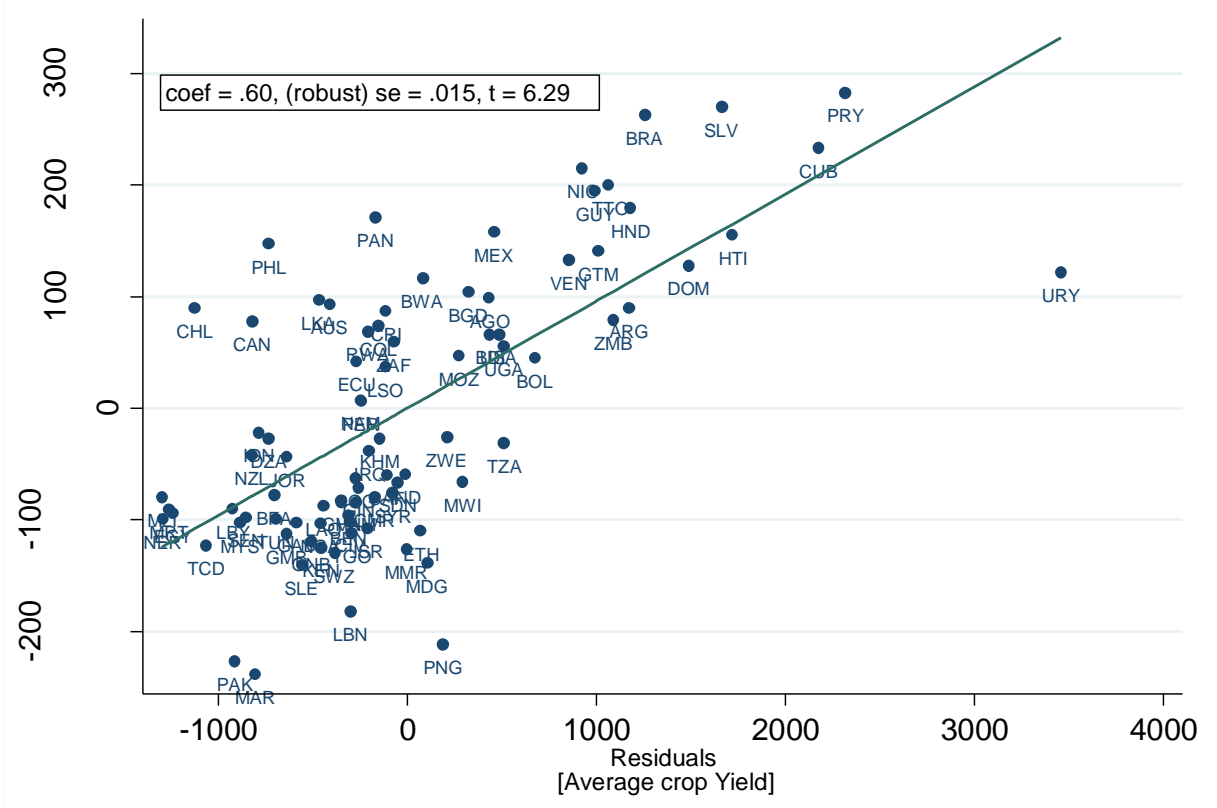

Notes: The partial regression line diagram illustrates the influence of average crop yield on the timing of colonization while partialing out the effects of other control variables, including latitude, mean elevation, variation in elevation, ruggedness, landlockedness, navigation distance from Europe, and distance from coast (see column (1d) of Table 3-2). The number of observations is 85 . 
In the last four columns of Table 3-2, we repeat the same exercise but focus instead on the duration of colonization. The results are qualitatively and quantitatively similar to those discussed for the timing of colonization. A greater average crop yield is associated with a longer duration of colonization. Moreover, while mean elevation loses significance, the negative coefficient of landockedness is now statistically significant at the $10 \%$ level. This supports the view that connectivity through sea routes to markets in Europe was an important factor for whether continued colonization was beneficial to the colonizers. Landlocked countries achieved independence sooner than other countries. Overall, our findings indicate that the colonizers sought to control more productive regions longer than other regions.

Figure 3-2 The association between colonization duration and average crop yield

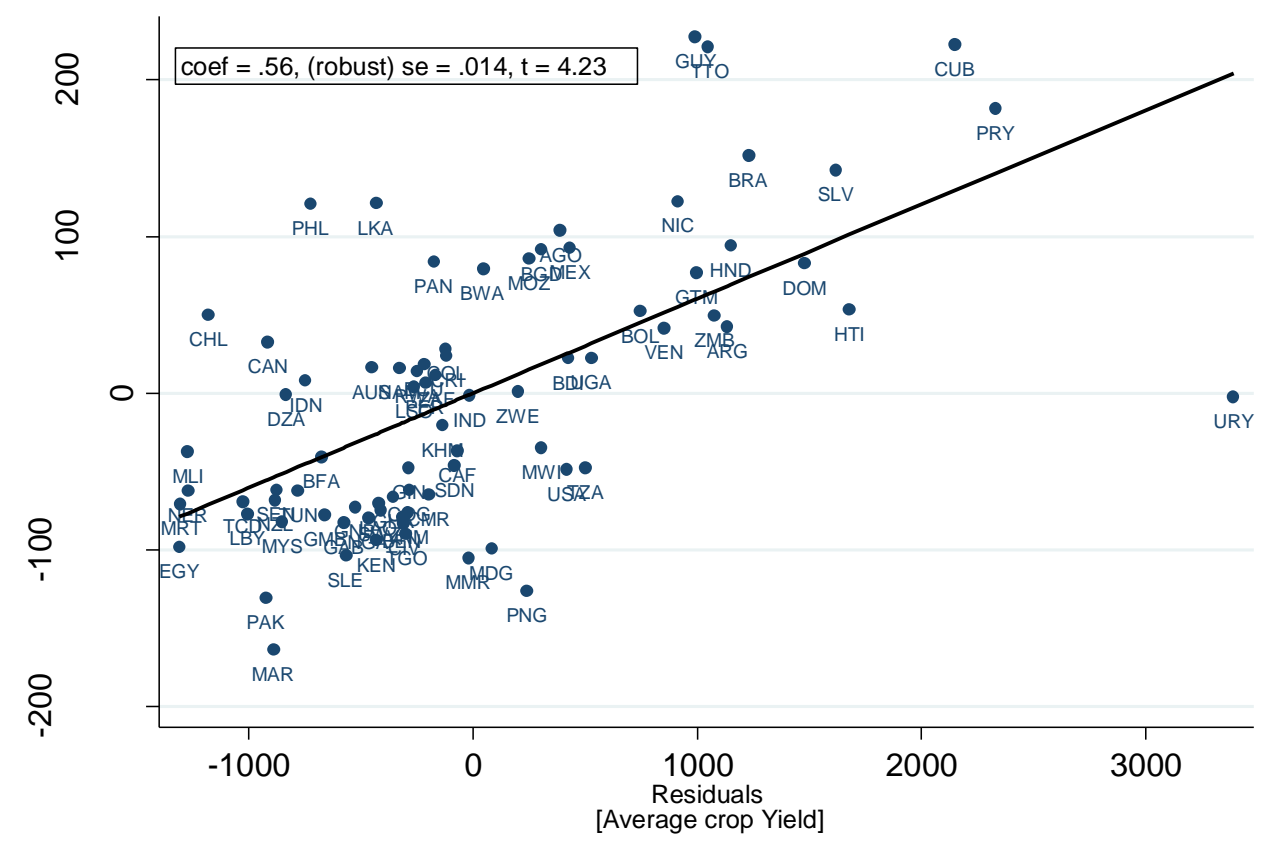

Notes: The partial regression line diagram illustrates the influence of average crop yield on the duration of colonization while partialing out the effects of other control variables, including latitude, mean elevation, variation in elevation, ruggedness, landlockedness, navigation distance from Europe, and distance from coast (See column (2d) of Table 3-2). The number of observations is 79 . 


\subsubsection{Robustness to Bias from Unobservables}

Although we have included some geographical controls in the estimations, there are still concerns that some unobservables may be correlated with average crop yield, and the timing or duration of colonization. To address this concern, we use an approach suggested by Altonji, Elder and Taber (2005). The basic idea is that the selection of observables may be used to estimate possible bias from unobservables. To assess the bias from unobservables, they suggest calculating the ratio $\frac{\widehat{\beta^{F}}}{\widehat{\beta^{R}-\widehat{\beta^{F}}}}$, where $\widehat{\beta^{F}}$ and $\widehat{\beta^{R}}$ are estimated coefficients of the full and restricted model, respectively.

This ratio explains how much stronger the selection on unobservables should be in comparison to the selection on observables for the estimated effect using observables to be explained away. The models presented in Table 3-2 have ratios equal to 12, 9, and 60 for columns (1a) to (1c), respectively, for the influence of average crop yield on the timing of colonization (note that column (1d) is the unrestricted model). The corresponding ratios are 9,9 , and 56 for columns (2a) to (2c), respectively. Since all ratios are equal or greater than 9 , the selection of unobservables must be much larger than the selection on observables in order to attribute the entire estimation effects to unobservables. Hence, our estimates are unlikely to be driven by unobservables.

\subsubsection{Robustness to Colonizer}

The possibility exists that the strategies and considerations of the colonizers representing the Spanish, British, French, Portuguese, and other empires, respectively, may have differed. In particular, they may have viewed the importance of agricultural productivity in different lights. Our results may therefore be driven by only a few colonizers. For example, the first major export products from Spanish America were silver and gold, initially looted from natives and later mined at heavy 
cost. However, soon the crops needed in the motherland became the main objective. In contrast, the British and the French came late to America. They colonized land that was sparsely inhabited by the native population and concentrated on agricultural activities.

Table 3-3 presents estimates obtained by sequentially dropping observations belonging to a particular colonizer. ${ }^{21}$ Note that the average crop yield coefficient sizes increase substantially after dropping all Spanish colonies in columns (1a) and (2a), while they decline in the remaining models. This supports the view that the Spanish colonizers were more interested in finding precious metals than expropriating the agricultural potential. Overall, the estimates remain robust. We conclude that a main objective for exploring and controlling new territories was to exploit the associated potential agricultural productivity. This appears to hold for all Western European colonizers.

Table 3-3 Robustness to the omission of each colonizer

\begin{tabular}{|c|c|c|c|c|c|c|c|c|}
\hline & (1a) & (1b) & (1c) & (1d) & (2a) & (2b) & $(2 \mathrm{c})$ & $(2 d)$ \\
\hline & \multicolumn{4}{|c|}{ Timing of colonization } & \multicolumn{4}{|c|}{ Duration of colonization } \\
\hline Average crop yield & $\begin{array}{c}0.77^{\text {*** }} \\
(5.84) \\
\end{array}$ & $\begin{array}{l}0.58^{* * * * *} \\
(5.89) \\
\end{array}$ & $\begin{array}{l}0.54^{\text {***k }} \\
(4.28)\end{array}$ & $\begin{array}{l}0.58^{* * * *} \\
(6.17) \\
\end{array}$ & $\begin{array}{l}0.71^{* * * *} \\
(4.62) \\
\end{array}$ & $\begin{array}{l}0.53^{\text {**** }} \\
(3.72) \\
\end{array}$ & $\begin{array}{l}0.51^{\text {***k }} \\
(2.92)\end{array}$ & $\begin{array}{c}0.54^{* * * *} \\
(4.02)\end{array}$ \\
\hline Baseline controls & Yes & Yes & Yes & Yes & Yes & Yes & Yes & Yes \\
\hline Omitted colonizer & Spain & Britain & France & Portugal & Spain & Britain & France & Portugal \\
\hline adj. $R^{2}$ & 0.46 & 0.71 & 0.60 & 0.61 & 0.40 & 0.62 & 0.46 & 0.50 \\
\hline$N$ & 66 & 52 & 61 & 81 & 60 & 49 & 57 & 75 \\
\hline
\end{tabular}

Notes: This table presents standardized beta coefficients by sequentially omitting observations of countries colonized by Spain, Britain, France, and Portugal. The dependent variable in the first four columns is the colonization timing whereas the next four columns use the duration of colonization as the outcome variable. The constant term is not reported for brevity. $t$ statistics are given in parentheses; *, $* *$, and $* * *$ represent statistical significance at $10 \%, 5 \%$, and $1 \%$ level. The baseline controls are absolute latitude, mean elevation, variation in elevation, ruggedness, landlockedness, navigational distance from Europe, and distance to coast.

\subsubsection{Robustness to Early Development Indicators}

In this sub-section, we study the potentially confounding influence of various early development indicators, including the timing of the transition to agriculture, the

${ }^{21}$ This approach is used since the number of observations for each colonizer is not sufficient to directly test our hypothesis by using dummies. 
history of statehood experience, the level of technology, population density, and the early disease environment. The transition from hunter/gatherer activities to agricultural practices induced the formation of early societies, which should have encouraged the formation of culture and early institutions. In turn, this may have a confounding influence on the decision to colonize new-found territories. The presence of strong pre-colonial institutions may have been an impediment to colonialization (see also Hariri (2012)).

Panel A of Table 3-4 reports the results using colonization timing as the dependent variable. Panel B reports the estimates for the duration of colonization. First, column (1) accounts for the timing of the agricultural transition; this has a statistically significant negative influence on the timing of colonization, but not it's duration. The coefficients of average crop yield remain precisely estimated.

The models in column (2) study the role of accumulated statehood experience at the time the colonization wave began around 1500AD. We note that the states that had weak or no presence of a state were the first to be colonized (column (2)). Similarly, technologically advanced states tended to be colonized later (column (3)). For instance, in $1500 \mathrm{AD}$ countries like China and India had superior technology in comparison to Europe, and thus the colonizers could not gain control over these territories until the technological gap was reduced or reversed a few centuries later. 
Table 3-4 Robustness to early development (average crop yield and years since colonization)

\begin{tabular}{|c|c|c|c|c|c|c|c|c|}
\hline & (1) & (2) & (3) & (4) & (5) & (6) & (7) & (8) \\
\hline & \multicolumn{8}{|c|}{ Panel A: Crop yield and Timing of colonization } \\
\hline Dep. Var. $=$ & \multicolumn{8}{|c|}{ Timing of colonization } \\
\hline Average crop yield & $\begin{array}{l}0.56^{6 * 3 *} \\
(5.75)\end{array}$ & $\begin{array}{l}0.53^{3 * 2} \\
(5.31)\end{array}$ & $\begin{array}{l}0.50^{*} \\
(4.80)\end{array}$ & $\begin{array}{l}0.55^{* * *} \\
(5.66)\end{array}$ & $\begin{array}{l}0.50^{* * * *} \\
(5.36)\end{array}$ & $\begin{array}{l}0.53^{* * * *} \\
(5.36)\end{array}$ & $\begin{array}{l}0.42^{2 * 3 *} \\
(4.53)\end{array}$ & $\begin{array}{l}0.27^{* 3} \\
(2.51)\end{array}$ \\
\hline $\begin{array}{l}\text { Years since agricultural } \\
\text { transition }\end{array}$ & $\begin{array}{c}- \\
0.17^{* * *} \\
(-2.91)\end{array}$ & & & & & & & $\begin{array}{c}-0.08 \\
(-0.86)\end{array}$ \\
\hline State history in 1500AD & & $\begin{array}{c}-0.18^{*} \\
(- \\
1.94)\end{array}$ & & & & & & $\begin{array}{c}-0.03 \\
(-0.31)\end{array}$ \\
\hline Technology in 1500AD & & & $\begin{array}{c}- \\
0.19^{* *} \\
(- \\
2.40)\end{array}$ & & & & & $\begin{array}{c}0.12 \\
(0.77)\end{array}$ \\
\hline Population density in $1500 \mathrm{AD}$ & & & & $\begin{array}{l}-{ }^{-} \\
0.21^{* * *} \\
(-2.99)\end{array}$ & & & & $\begin{array}{c}0.11 \\
(1.24)\end{array}$ \\
\hline Early disease environment & & & & & $\begin{array}{c}-{ }^{-} \\
0.39^{* * *} \\
(-4.59)\end{array}$ & & & $\begin{array}{l}-0.20^{*} \\
(-1.73)\end{array}$ \\
\hline Biogeography & & & & & & $\begin{array}{l}- \\
0.22^{* * *} \\
(-3.02)\end{array}$ & & $\begin{array}{c}- \\
0.40^{* * *} \\
(-2.74)\end{array}$ \\
\hline Human Settlement & & & & & & & $\begin{array}{c}- \\
0.49^{* * *} \\
(-4.77)\end{array}$ & $\begin{array}{c}- \\
0.57^{* * *} \\
(-3.54)\end{array}$ \\
\hline Baseline controls & Yes & Yes & Yes & Yes & Yes & Yes & Yes & Yes \\
\hline adj. $R^{2}$ & 0.63 & 0.63 & 0.63 & 0.64 & 0.68 & 0.64 & 0.72 & 0.79 \\
\hline \multirow[t]{3}{*}{ Observations } & 85 & 85 & 85 & 85 & 85 & 85 & 82 & 82 \\
\hline & (1) & (2) & (3) & (4) & (5) & (6) & $(7)$ & (8) \\
\hline & \multicolumn{8}{|c|}{ Panel B: Crop yield and Duration of colonization } \\
\hline Dep. Var. $=$ & & & & uration o & colonizat & & & \\
\hline Average crop yield & $\begin{array}{l}0.54^{* * * *} \\
(3.92)\end{array}$ & $\begin{array}{l}0.54^{* * * *} \\
(3.78)\end{array}$ & $\begin{array}{l}0.53^{* * * *} \\
(3.73)\end{array}$ & $\begin{array}{l}0.54^{* * * m} \\
(4.03)\end{array}$ & $\begin{array}{l}0.50^{* * *} \\
(3.73)\end{array}$ & $\begin{array}{l}0.52^{* * * *} \\
(3.82)\end{array}$ & $\begin{array}{l}0.37^{* * * 6} \\
(2.66)\end{array}$ & $\begin{array}{l}0.32^{* *} \\
(2.13)\end{array}$ \\
\hline $\begin{array}{l}\text { Years since agricultural } \\
\text { transition }\end{array}$ & -0.11 & & & & & & & -0.09 \\
\hline State history in 1500AD & $(-1.38)$ & $\begin{array}{c}-0.07 \\
(- \\
0.63)\end{array}$ & & & & & & $\begin{array}{c}(-0.52) \\
0.02 \\
(0.12)\end{array}$ \\
\hline Technology in 1500AD & & & $\begin{array}{c}-0.06 \\
(- \\
0.73)\end{array}$ & & & & & $\begin{array}{c}0.19 \\
(0.99)\end{array}$ \\
\hline Population density in $1500 \mathrm{AD}$ & & & & $\begin{array}{l}-0.12 \\
(-1.29)\end{array}$ & & & & $\begin{array}{c}0.11 \\
(0.82)\end{array}$ \\
\hline Early disease environment & & & & & $\begin{array}{l}-0.27^{* *} \\
(-2.57)\end{array}$ & & & $\begin{array}{l}-0.12 \\
(-0.84)\end{array}$ \\
\hline Biogeography & & & & & & $\begin{array}{c}-0.11 \\
(-1.34)\end{array}$ & & $\begin{array}{l}-0.32^{* *} \\
(-2.43)\end{array}$ \\
\hline Human Settlement & & & & & & & $\begin{array}{c}- \\
0.50^{* * *} \\
(-3.71)\end{array}$ & $\begin{array}{c}- \\
0.54^{* * *} \\
(-2.96)\end{array}$ \\
\hline Baseline controls & Yes & Yes & Yes & Yes & Yes & Yes & Yes & Yes \\
\hline $\operatorname{adj} . R^{2}$ & 0.50 & 0.50 & 0.50 & 0.50 & 0.53 & 0.50 & 0.61 & 0.62 \\
\hline Observations & 79 & 79 & 79 & 79 & 79 & 79 & 76 & 76 \\
\hline
\end{tabular}

Notes: this table presents standardized beta coefficients by controlling for some effects of early development. The dependent variable in panel A is the colonization timing whereas panel B uses the duration of colonization as the outcome variable. $t$ statistics are given in parentheses; *, **, and *** represent statistical significance at 10\%, 5\%, and 1\% level. The baseline controls are absolute latitude, mean elevation, variation in elevation, ruggedness, landlockedness, navigational distance from Europe, and distance to coast. 
In contrast, superior technologies (including horses and gunpowder) allowed fewer than six hundred Spanish men, led by Hernando Cortez, to conquered the Aztec empire with millions of subjects (McNeill (1998), pp. 19). However, statehood experience the level of technology had no bearing on the duration of colonization.

Population density is also an indicator of early development. ${ }^{22}$ The colonizers were in direct competition with the native population for control of natural resources, but also needed their labor. We account for population density in year 1500 in column (4). Population density reduces the probability of early colonization but not its duration, similarly to the other early development indicators. The influence of average crop yield on the timing of colonization remains robust and statistically significant.

Next, we account for the early disease environment. Africa is geographically close to Europe and was known to the Europeans for many centuries before they started colonizing African territories in the eighteenth century. Even then, most outposts in Africa were established to support the spice trade with South and East Asia. One plausible reason for this reluctance to colonize African countries may be due to the presence of an adverse disease environment (Acemoglu, Johnson and Robinson (2001)). For example, yellow fever and malaria were widespread across the African continent. Reversely, in the Americas the Europeans affected the native population severely negatively by bringing new diseases. A large population of aborigines died in the Americas as a result. These observations suggest a negative association between early disease environment and the timing and duration of colonization. The results reported in column (5) support this hypothesis.

\footnotetext{
${ }^{22}$ According to Malthusian theory, economic development does not increase per capita income due to the consequent population growth.
} 
Column (6) accounts for countries' biogeography. Olsson and Hibbs (2005) argue that the initial geographical and biological conditions in the prehistoric era influenced agricultural productivity and affected development. Similarly, Diamond (1997) argues that the geographical endowment of Eurasia - the large size of the Eurasian continent, the large Mediterranean zone in the western part, the East-West orientation of its major axis - a disproportionately-sized endowment of plants suited for cultivation, and animals suited for domestication, made Eurasia a more likely place for early development. Hence, the agricultural revolution occurred earlier in Eurasia than anywhere else. Our findings in column (6) support the argument that more advanced countries were colonized later, although the duration was unaffected. The influence of average crop yield remains unchanged.

Ahlerup and Olsson (2012) argue that a longer settlement history is associated with more ethnic and ethnolinguistic diversity. Internal social diversity among the native population may have played a role in the decision regarding when, and how long, to colonize a region. ${ }^{23}$ We use Ahlerup and Olsson's (2012) measure of duration of human settlement to account for the effect of internal social diversity. The results reported in column (7) indicate that a history of human settlement has a negative influence on both the timing and duration of colonization. In both cases, the influence of average crop yield remains statistically significant at the $1 \%$ level, however.

Finally, in column (8) we run a horse-race between all early development indicators included in the earlier models. The influence of average crop yield on the timing and duration of colonization is robust and statistically significant (at the $5 \%$ level).

\footnotetext{
${ }^{23}$ For instance, British colonial rule in India began after the decisive victory of the East India Company over the ruler of a large Indian state in the Battle of Plassey. Internal social diversity and mistrust among the native rulers of neighboring states was one reason for this victory.
} 
Among the control variable, only early disease environment (timing model only), biogeography, and human settlement stay significant at conventional levels. Note that these findings should be interpreted with caution, however, as some of the early development indicators exhibit high correlations.

\subsubsection{Robustness to the Inclusion of Other Covariates}

While it appears that agricultural productivity (here measured as average crop yield) was an important determinant of the timing and duration of colonization, we recognize that land productivity was perhaps frequently not immediately detectable to many sea captains, noblemen, and other scouting for new lands. Instead, they may have used proxies such as temperature and precipitation in their decisions.

The results are reported in Table 3-5. Columns (1a) and (2a) control for the influence of temperature and precipitation. ${ }^{24}$ While the findings indicate that the level of precipitation had a positive effect on the timing and duration of colonization, temperature and water availability does not appear to have impacted those decisions. Human survival and agricultural productivity depend critically on the availability of fresh water. The men who arrived in present-day Virginia in 1607 soon (by the end of the following summer) suffered from a shortage of high quality water, for example. Since data on the volume of fresh water available at the beginning of colonization are unavailable, we use the total surface of all inland water bodies (including lakes, reservoirs, and rivers) as a fraction of the total land area as a proxy for the availability of fresh water. The results provided in columns (1b) and (2b) do not provide support for this particular hypothesis.

\footnotetext{
${ }^{24}$ There are no official records of temperature and precipitation before 1900 for most of the countries. We assume that the average temperature and precipitation did not change much over the five centuries and use average temperature and precipitation for recent years, 1961-1990.
} 
Table 3-5 Robustness to the inclusion of other covariates

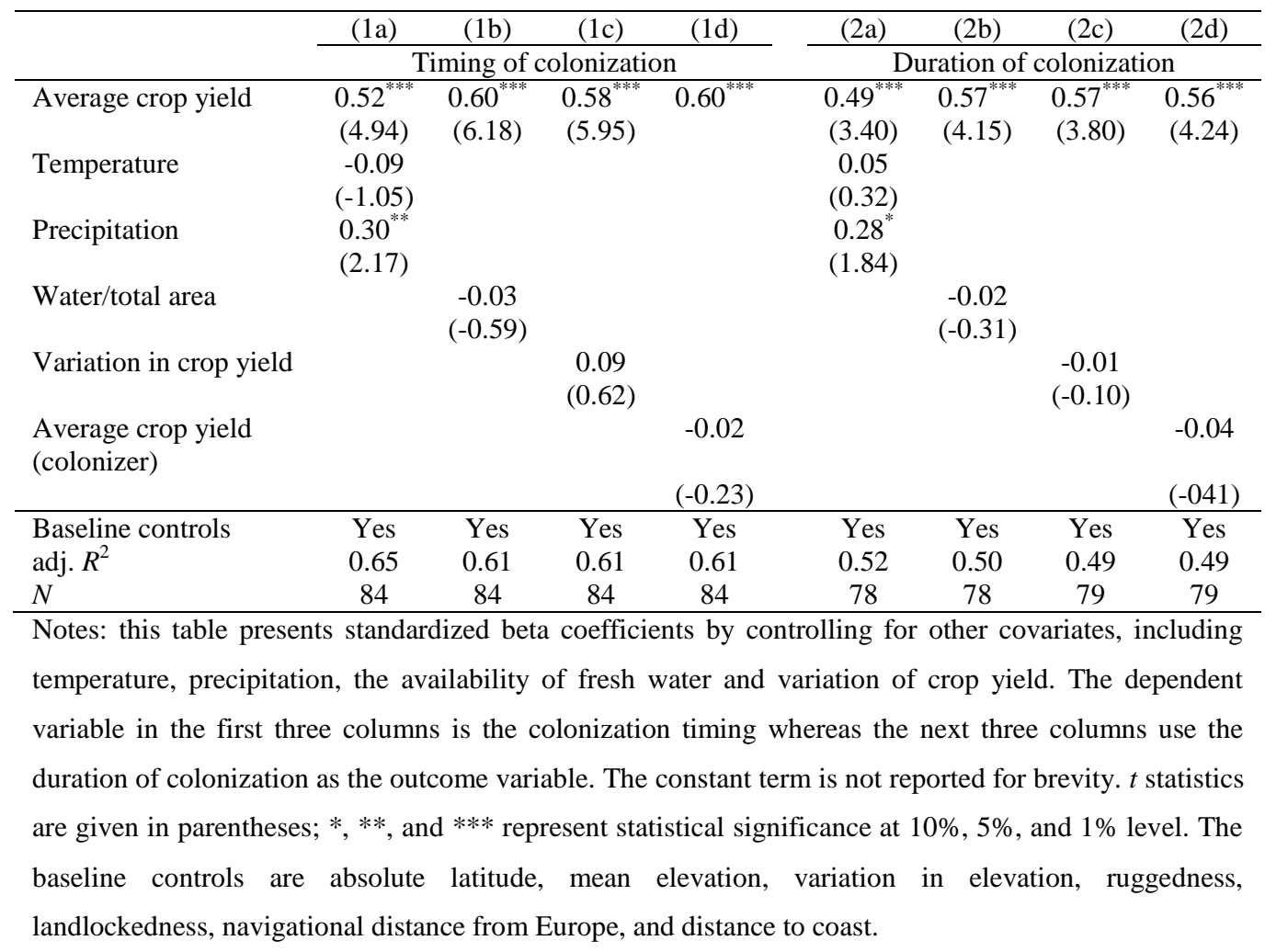

Finally, the variation of crop yield checks whether colonization was affected by the degree of inequality in agricultural productivity. However, the variation in crop yield is insignificant in columns (1c) and (2c). Further, various colonizers might have different objective depending on their own crop yield conditions. Columns (1d) and (2d) control for average crop yield in home country of colonizer to account for this influence. The effect of crop yield remains significant. Importantly, our main results remain robust throughout all models in Table 3-5.

We notice that the coefficient on the crop yield index changes little when weather variables (temperature, rainfall, water) are included as controls. These results may suggest that the positive correlation between crop yield and duration of colonization 
is driven by factors other than the weather. However, this is probably because the crop yield measure has already captured a lot of agriculturally related climatic information, leaving little room for these variables to explain the outcome.

\subsubsection{Other Robustness Checks}

This sub-section presents several additional findings using alternative samples, a different measure of agricultural productivity, an alternative estimation method, and some other measures of colonization.

The pace and characteristics of colonization changed over time. We therefore divide our sample into two subgroups, where the early wave of colonization (mercantile wave) during the Age of Discovery lasted until $1700 \mathrm{AD}$, and the subsequent period can be denoted imperialist colonization (Olsson (2009)). ${ }^{25}$

The early explorers were looking for alternative spice trade routes to the East Indies. Their scant knowledge of navigational routes beyond the Atlantic took them to the Americas where the sailors discovered a sparsely populated vast land. However, the results presented in columns (1) and (2), Panel A in Table 3-6, indicate that the influence of average crop yield on the timing of colonization is unchanged before and after $1700 \mathrm{AD}$. Note that the crop yield coefficient and the adjusted $R^{2}$ value in column (1) are considerably higher than in column (2). This lends support to the view that the colonizers were in greater need of fertile land for their survival in the earlier time period than later one. The ability to transport food on their own ships was limited, and to continuously importing food from their motherland was not commercially viable. Consistent with this perspective, the effect of average crop yield

\footnotetext{
${ }^{25}$ The first wave of mercantile colonization finished by 1700 and a new wave of imperial colonization began after this. This also marked the beginning of Age of Enlightenment in Europe.
} 
on the duration of colonization is found to be significant only for the pre-1700 period.

Post-1700, food imports were likely more feasible from more nearby colonies.

In order to mitigate any concern that our results are influenced by the choice of land productivity measure, we also use the land suitability index produced by Ramankutty,

Foley, et al. (2002). This index reflects how suitable a land is for farming based on soil quality and climate, and ranges from 0 and 1 . The results in column (3) indicate a robust and statistically significant association between land suitability and the timing and duration of colonization, thus reinforcing our earlier findings.

Table 3-6 Other robustness checks

\begin{tabular}{|c|c|c|c|c|c|c|}
\hline & (1) & (2) & (3) & $(4)$ & (5) & (6) \\
\hline & \multicolumn{6}{|c|}{ Panel A: Crop yield and Timing of colonization } \\
\hline Dep. Var. $=$ & Colyr & colyr & colyr & colyr & $\ln ($ colyr $)$ & $\begin{array}{c}\text { colyr of Olsson } \\
(2009)\end{array}$ \\
\hline Average crop yield & $\begin{array}{l}0.73^{* * *} \\
(3.72)\end{array}$ & $\begin{array}{l}0.38^{* * *} \\
(3.92)\end{array}$ & & $\begin{array}{l}0.47^{* * *} \\
(5.36)\end{array}$ & $\begin{array}{l}0.58^{* * *} \\
(7.00)\end{array}$ & $\begin{array}{l}0.47^{* * * *} \\
(5.36)\end{array}$ \\
\hline Land suitability & & & $\begin{array}{c}0.43^{\text {**** }} \\
(3.96)\end{array}$ & & & \\
\hline Baseline controls & Yes & Yes & Yes & Yes & Yes & Yes \\
\hline adj. $R^{2}$ & 0.50 & 0.24 & 0.42 & - & 0.57 & 0.46 \\
\hline Sample & $\begin{array}{c}\text { Pre-1700 } \\
\text { colonization } \\
\text { only }\end{array}$ & $\begin{array}{c}\text { Post-1700 } \\
\text { colonization } \\
\text { only }\end{array}$ & Full & Full & Full & Full \\
\hline $\begin{array}{l}\text { Method of } \\
\text { estimation }\end{array}$ & OLS & OLS & OLS & Neg. Binomial & OLS & OLS \\
\hline \multirow[t]{2}{*}{ Observations } & 25 & 60 & 85 & 79 & 85 & 79 \\
\hline & \multicolumn{6}{|c|}{ Panel B: Crop yield and Duration of colonization } \\
\hline Dep. Var. $=$ & Coldr & coldr & doldr & coldr & $\ln ($ coldr $)$ & $\begin{array}{c}\text { coldr of Olsson } \\
\text { (2009) }\end{array}$ \\
\hline Average crop yield & $\begin{array}{l}0.48^{*} \\
(2.01)\end{array}$ & $\begin{array}{c}0.18 \\
(1.41)\end{array}$ & & $\begin{array}{l}0.34^{* * *} \\
(5.07)\end{array}$ & $\begin{array}{l}0.56^{\text {*N*** }} \\
(4.58)\end{array}$ & $\begin{array}{l}0.35^{* * *} \\
(3.28)\end{array}$ \\
\hline Land suitability & & & $\begin{array}{l}0.39^{* * * *} \\
(2.67)\end{array}$ & & & \\
\hline Baseline controls & Yes & Yes & Yes & Yes & Yes & Yes \\
\hline adj. R2 & 0.15 & 0.11 & 0.31 & - & 0.51 & 0.28 \\
\hline Sample & Pre 1700 & Post 1700 & Full & Full & Full & Full \\
\hline $\begin{array}{l}\text { Method of } \\
\text { estimation }\end{array}$ & OLS & OLS & OLS & Neg. Binomial & OLS & OLS \\
\hline Observations & 25 & 54 & 79 & 79 & 79 & 79 \\
\hline
\end{tabular}

Notes: this table presents standardized beta coefficients by considering alternative samples, approaches and outcome measures. The dependent variable in panel A is the colonization timing (colyr) whereas panel B uses the duration of colonization (coldr) as the outcome variable. The constant term is not reported for brevity. $t$ statistics are given in parentheses; $*, * *$, and $* * *$ represent statistical significance at $10 \%, 5 \%$, and $1 \%$ level. The baseline controls are absolute latitude, mean elevation, variation in elevation, ruggedness, landlockedness, navigational distance from Europe, and distance to coast. Column (1) uses pre-1700 colonization data only whereas column (2) uses data for the post-1700 period only. Column (3) replaces crop yield with land suitability. Column (4) uses a negative binomial estimator. In column (5), the dependent variables are log-transformed. Column (6) uses the colonization data of Olsson (2009) to construct the outcome measures. 
Our outcome variable focused on the timing of colonization is positively skewed by definition. The negative binomial estimator is consequently an appropriate estimation method, which we utilize in column (4). We find that the influence of average crop yield on both the timing and the duration of colonization remains statistically significant at the $1 \%$ level when this alternative approach is used. Next, we log transform the outcome variables to get more normal distribution (column (5)); the results remain largely intact. Finally, we use an alternative dataset from Olsson (2009) to construct our outcome measures. The result is presented in column (6). Reassuringly, the results are consistent.

\subsubsection{Robustness to Selection Bias}

Since some countries were never colonized, selection bias may potentially have affected our OLS results presented above. It would be of major concern if this were the case. We address such concerns by using Heckman's (1979) two-step regression approach. In the first step, we find the determinants of colonization. In the second step, the regressions presented in Table 2 are repeated.

Ideally, all countries should be included in the first step regression model. However, a number of small countries have miniscule population sizes. Following Ertan et al. (2016), we focus on 111 non-European countries for which navigational distance data is available, and which either were or could have been colonized by a Western European power ${ }^{26}$. These countries accounted for $95.4 \%$ of the world's population outside of Western Europe. However, data for all control variables are unavailable.

\footnotetext{
${ }^{26}$ The results for the two-step Heckman's (1979) model are robust when extending the analysis to 173 countries, which necessitates dropping the navigation distance variable.
} 
Finally, we are left with 103 observations; 85 former colonies, and 18 countries that were never colonized.

In the first step model, we include the full set of control variables: average crop yield, latitude, mean elevation, variation in elevation, ruggedness, landlockedness, navigational distance, and land distance from nearest coast. The results of the second step of the selection bias model are reported in Table 8 . The findings are qualitatively and quantitatively similar to those shown in Table 2 . These findings suggest that the hypothesis of 'no selection bias' cannot be rejected in any of the specifications. We may therefore assume that our main results are not affected by selection bias.

Table 3-7 Potential crop yield and colonization: Heckman Selection Model

\begin{tabular}{|c|c|c|c|c|c|c|c|c|}
\hline & (1a) & (1b) & (1c) & (1d) & $(2 a)$ & (2b) & $(2 \mathrm{c})$ & $(2 \mathrm{~d})$ \\
\hline Dependent variable & \multicolumn{4}{|c|}{ Timing of colonization } & \multicolumn{4}{|c|}{ Duration of colonization } \\
\hline Average crop yield & $\begin{array}{c}0.64^{* * * *} \\
(7.89)\end{array}$ & $\begin{array}{c}0.64^{\text {**** }} \\
(7.84)\end{array}$ & $\begin{array}{c}0.59^{* * * *} \\
(8.14)\end{array}$ & $\begin{array}{c}0.59^{* * * *} \\
(6.55)\end{array}$ & $\begin{array}{c}0.59^{* * * *} \\
(6.64)\end{array}$ & $\begin{array}{c}0.58^{* * * *} \\
(6.46)\end{array}$ & $\begin{array}{c}0.54^{* * * *} \\
(6.73)\end{array}$ & $\begin{array}{c}0.54^{\text {**** }} \\
(6.69)\end{array}$ \\
\hline Absolute Latitude & & $\begin{array}{c}0.15 \\
(1.28)\end{array}$ & $\begin{array}{c}0.08 \\
(0.80)\end{array}$ & $\begin{array}{c}0.12 \\
(0.60)\end{array}$ & & $\begin{array}{c}0.10 \\
(0.66)\end{array}$ & $\begin{array}{c}-0.04 \\
(-0.25)\end{array}$ & $\begin{array}{c}-0.07 \\
(-0.32)\end{array}$ \\
\hline Mean elevation & & & $\begin{array}{c}-0.25 \\
(-1.63)\end{array}$ & $\begin{array}{c}-0.29 \\
(-1.53)\end{array}$ & & & $\begin{array}{c}-0.18 \\
(-0.97)\end{array}$ & $\begin{array}{c}-0.23 \\
(-1.11)\end{array}$ \\
\hline Variation in elevation & & & $\begin{array}{c}0.57^{* * * *} \\
(5.53)\end{array}$ & $\begin{array}{c}0.62^{* * * *} \\
(4.78)\end{array}$ & & & $\begin{array}{c}0.43^{* * * *} \\
(3.54)\end{array}$ & $\begin{array}{c}0.47^{\text {**** }} \\
(3.54)\end{array}$ \\
\hline Ruggedness & & & $\begin{array}{c}-0.03 \\
(-0.33)\end{array}$ & $\begin{array}{c}0.00 \\
(0.04)\end{array}$ & & & $\begin{array}{c}0.02 \\
(0.15)\end{array}$ & $\begin{array}{c}0.05 \\
(0.39)\end{array}$ \\
\hline Landlockedness & & & $\begin{array}{c}-0.07 \\
(-0.75)\end{array}$ & $\begin{array}{c}-0.17 \\
(-0.92)\end{array}$ & & & $\begin{array}{c}-0.16 \\
(-1.41)\end{array}$ & $\begin{array}{c}-0.16 \\
(-0.71)\end{array}$ \\
\hline Navigation distance & & & & $\begin{array}{c}-0.04 \\
(-0.26)\end{array}$ & & & & $\begin{array}{c}-0.09 \\
(-0.72)\end{array}$ \\
\hline Distance to coast & & & & $\begin{array}{c}0.23 \\
(0.87)\end{array}$ & & & & $\begin{array}{c}0.04 \\
(0.17)\end{array}$ \\
\hline Mills/lambda & $\begin{array}{c}-0.01 \\
(-0.02)\end{array}$ & $\begin{array}{c}-0.66 \\
(-0.77)\end{array}$ & $\begin{array}{c}-0.85 \\
(-1.16)\end{array}$ & $\begin{array}{c}-1.19 \\
(-0.71)\end{array}$ & $\begin{array}{c}-0.04 \\
(-0.12)\end{array}$ & $\begin{array}{c}-0.26 \\
(-0.54)\end{array}$ & $\begin{array}{c}-0.14 \\
(-0.26)\end{array}$ & $\begin{array}{c}-0.01 \\
(-0.01)\end{array}$ \\
\hline Observations & 103 & 103 & 103 & 103 & 103 & 103 & 103 & 103 \\
\hline
\end{tabular}

Notes: This table presents standardized beta coefficients from two-step Heckman selection model. The independent variables used in the first-step probit regression are average crop yield, latitude, mean elevation, variation in elevation, ruggedness, landlockedness, navigational distance, and land distance from nearest coast. The dependent variable in the first four columns is the colonization timing whereas the next four columns use the duration of colonization as the outcome variable. The constant term is not reported for brevity. $t$ statistics are given in parentheses; *,**, and *** represent statistical significance at $10 \%, 5 \%$, and $1 \%$ level. 


\subsection{Grid Cell Level Analysis}

This section presents results obtained using grid cell level data. The world is divided into one-by-one minute degree grid cells of 1 by 1 decimal degree. We retrieve data for average crop yield and the controls variables at the grid cell level. This method of estimation mitigates concern of potential endogeneity problems that may arise in the cross-section study.

We assume that a grid cell was under colonial rule if it is part of a present-day country that was once colonized. We are aware that this assumption may draw some criticism. For example, the year of colonization is estimated to be 1758 for India. This is the year when the British colonists, under the label of the East India Company, became a dominant political force in India and controlled over $20 \%$ of territories or population (this qualifies India as a British colony according to the criteria used by Ertan, Fiszbein and Putterman (2016)). However, Portuguese and Dutch colonists had established trading posts in India almost one hundred years earlier, although their influence remained concentrated in some small coastal areas. While ideally we should take the separate years of colonization by different colonists into account when performing the grid cell level analysis, such as task is infeasible considering the scant information available and the scope of our study. Caution should be exercised when interpreting these findings. 
Table 3-8 presents our results from estimating the same model as in the earlier crosscountry analysis, after clustering the standard errors at the country level. Column (1a) shows that the unconditional influence of average crop yield on the timing of colonization is statistically significant. We then progressively augment our specification similarly, to the approach used in Table 3-2 for the cross-country analysis. Our findings suggest that the influence of average crop yield on the timing of colonization remains robust throughout (columns (1b) to (1d)).

Another concern is that the results are influenced by a few large countries in our sample. The largest number of grid cells is lying inside the borders of the United States and Canada, and both countries were colonized. To address this concern, we remove all observations from these two countries. The results reported in column (1e) highlight that our results do not appear to be vulnerable to this concern.

Next, we repeat these robustness exercises for the duration of colonization. The results reported in columns (2a) to (2d) indicate that average crop yield has a statistically significant (5\% level) positive effect on the duration of colonization. Moreover, it remains significant when the grid-cell observations from the Canada and the United States are removed. Note also that in this case both the adjusted $R^{2}$ and the size of the coefficient increase substantially. One plausible explanation for this observation is that both Canada and the United States were predominantly inhabited by Europeans and their descendants ${ }^{27}$. They may have inherited some values of independence and democracy from their ancestors who originate from Europe. There was therefore a lower probability of prolonged subjugation of one group of people by

\footnotetext{
${ }^{27}$ We do not rule out possibility that this increase in the coefficient may just be that the variation is now greater as a large number of observations with the same independence date were removed.
} 
another group. Our results also hold when in addition Australia and Brazil (with relatively fewer grid cells), along with the United States and Canada, are excluded from the estimations. The results are not reported in order to conserve space (available upon request). 
Table 3-8 Average crop yield and colonization (Grid size 1 by 1 decimal degree)

\begin{tabular}{|c|c|c|c|c|c|c|c|c|c|c|}
\hline & (1a) & (1b) & $(1 \mathrm{c})$ & $(1 \mathrm{~d})$ & (1e) & (2a) & (2b) & $(2 c)$ & $(2 d)$ & (2e) \\
\hline & \multicolumn{5}{|c|}{ Timing of colonization } & \multicolumn{5}{|c|}{ Duration of colonization } \\
\hline Average crop yield & $\begin{array}{l}0.39^{* * * *} \\
(2.64)\end{array}$ & $\begin{array}{l}0.45^{* * *} \\
(3.36)\end{array}$ & $\begin{array}{l}0.45^{* * *} \\
(3.66)\end{array}$ & $\begin{array}{c}0.42^{\text {***** }} \\
(3.46)\end{array}$ & $\begin{array}{c}0.48^{* * *} \\
(4.96)\end{array}$ & $\begin{array}{l}0.40^{* *} \\
(2.26)\end{array}$ & $\begin{array}{l}0.40^{* *} \\
(2.11)\end{array}$ & $\begin{array}{l}0.41^{* *} \\
(2.22)\end{array}$ & $\begin{array}{l}0.39^{* *} \\
(2.25)\end{array}$ & $\begin{array}{c}0.51^{\text {**** }} \\
(4.78)\end{array}$ \\
\hline Latitude (absolute) & & $\begin{array}{c}0.18 \\
(1.33)\end{array}$ & $\begin{array}{c}0.20 \\
(1.45)\end{array}$ & $\begin{array}{c}-0.06 \\
(-0.34)\end{array}$ & $\begin{array}{c}-0.29^{* * * *} \\
(-2.67)\end{array}$ & & $\begin{array}{c}0.02 \\
(0.10)\end{array}$ & $\begin{array}{c}0.03 \\
(0.16)\end{array}$ & $\begin{array}{c}-0.18 \\
(-0.90)\end{array}$ & $\begin{array}{c}-0.16 \\
(-1.39)\end{array}$ \\
\hline Mean elevation & & & $\begin{array}{c}0.01 \\
(0.10)\end{array}$ & $\begin{array}{c}0.01 \\
(0.11)\end{array}$ & $\begin{array}{c}0.06 \\
(0.85)\end{array}$ & & & $\begin{array}{c}-0.01 \\
(-0.11)\end{array}$ & $\begin{array}{c}-0.02 \\
(-0.23)\end{array}$ & $\begin{array}{c}0.09 \\
(1.20)\end{array}$ \\
\hline Variation in elevation & & & $\begin{array}{c}0.23^{* * *} \\
(4.04)\end{array}$ & $\begin{array}{c}0.21^{* * * *} \\
(5.14)\end{array}$ & $\begin{array}{c}0.20^{* * * *} \\
(4.46)\end{array}$ & & & $\begin{array}{c}0.26^{* * * *} \\
(5.14)\end{array}$ & $\begin{array}{c}0.24^{* * * *} \\
(5.30)\end{array}$ & $\begin{array}{c}0.18^{* * *} \\
(4.52)\end{array}$ \\
\hline Ruggedness & & & $\begin{array}{c}-0.09 \\
(-1.30)\end{array}$ & $\begin{array}{c}-0.05 \\
(-0.73)\end{array}$ & $\begin{array}{c}-0.10 \\
(-1.54)\end{array}$ & & & $\begin{array}{c}-0.09 \\
(-1.50)\end{array}$ & $\begin{array}{c}-0.05 \\
(-0.76)\end{array}$ & $\begin{array}{c}-0.08 \\
(-1.09)\end{array}$ \\
\hline Landlocked & & & & $\begin{array}{c}-0.32^{* * * * *} \\
(-3.82)\end{array}$ & $\begin{array}{c}-0.24^{* * *} \\
(-2.79)\end{array}$ & & & & $\begin{array}{c}-0.27^{* * * *} \\
(-2.86)\end{array}$ & $\begin{array}{l}-0.21^{* *} \\
(-2.32)\end{array}$ \\
\hline Distance via sea & & & & $\begin{array}{l}-0.23^{*} \\
(-1.96)\end{array}$ & $\begin{array}{l}-0.18^{* *} \\
(-2.21)\end{array}$ & & & & $\begin{array}{c}-0.16 \\
(-1.18)\end{array}$ & $\begin{array}{c}-0.14 \\
(-1.36)\end{array}$ \\
\hline Distance from coast & & & & $\begin{array}{c}0.12 \\
(1.46) \\
\end{array}$ & $\begin{array}{c}-0.02 \\
(-0.17) \\
\end{array}$ & & & & $\begin{array}{c}0.13 \\
(1.59) \\
\end{array}$ & $\begin{array}{c}-0.05 \\
(-0.46) \\
\end{array}$ \\
\hline Baseline controls & Yes & Yes & Yes & Yes & Yes & Yes & Yes & Yes & Yes & Yes \\
\hline Sample & Global & Global & Global & Global & Excl. USA \& Canda & Global & Global & Global & Global & Excl. USA \& Canda \\
\hline $\operatorname{adj} . R^{2}$ & 0.15 & 0.18 & 0.21 & 0.33 & 0.47 & 0.16 & 0.16 & 0.20 & 0.27 & 0.42 \\
\hline$N$ & 11214 & 11214 & 11214 & 11214 & 7679 & 10966 & 10966 & 10966 & 10966 & 7431 \\
\hline
\end{tabular}

Notes: This table presents standardized beta coefficients of average crop yield on years since colonization before 2000 AD. All the control variables - absolute latitude, mean elevation, variation in elevation, ruggedness, landlockedness, navigational distance from Europe, and distance to coast - are computed at grid level of size 1 by 1 degree decimal. Constant term is included in all the regression, but not reported for brevity. $t$ statistics are given in parentheses; *,**, and *** represent statistical significance at $10 \%, 5 \%$, and $1 \%$ level. 


\subsection{Conclusions}

Agroecology in general, and geography and climate in particular, have become important research topics in economics. These are as part of a broader agenda to understand the deep roots of comparative development. The recent literature has identified the persistent influence of historic events and how they play a role in shaping the characteristics of institutions and culture. Colonization is one such major event that has influenced world history. However, there is considerable ambiguity as to which specific aspects of geography and climate influenced the likelihood of a territory succumbing to colonization, and remaining a colony.

This study contributes to this small literature by identifying the role of soil productivity (average crop yield) as an important factor for the timing and duration of colonization. We hypothesize that the colonists preferred to control a region with higher crop yield because it improved their own chances of survival and offered the opportunity to export agricultural products back to the mother country. Historical evidence shows that the colonists established settler colonies in regions that were sparsely populated and allowed large agricultural plantations. Agricultural productivity therefore played a key role in colonial history.

Our empirical findings are strengthened by the use of alternative measures of timing of colonization, the inclusion of a number of possible confounders, and alternative empirical regression methods. The results remain consistent when grid cell level data are used to mitigate the possibility of endogeneity arising from the use of information based on present-day country borders. 


\section{Appendix}

\section{A. Outcome variables}

Timing of colonization. This outcome variable is measured as the number of years elapsed, in $2000 \mathrm{AD}$, since colonization by Europeans was estimated to occur. The data are compiled by Ertan, Fiszbein and Putterman (2016), who use some quantitative and objective criteria to identify the date of colonization. According to their criteria, the process of colonization is considered to have started in a country when " $20 \%$ or more of a country's territory was largely under the control of the colonizing power, provided that the majority of the territory would eventually be controlled either by the same authority or by another colonizer.

Duration of colonization. This variable is measured as the number of years that a country was under colonial rule. It constructed by taking the difference between the year of independence and the first year of colonization identified by Olsson (2009).

\section{B. Explanatory variable}

Potential Average Crop Yield. This index captures potential average crop yield (measured in millions of kilocalories per hectare per year) across different regions in a country. Crop yield index is constructed using crop yield (measured in tons per hectare per year) from Global Agro-Ecological Zones (GAEZ) project of Food and Agriculture Organization (FAO) and caloric content of various crops from US Department of Agriculture Nutrient Database for Standard Reference (source: Galor and Özak (2016)).

Land suitability. This index, which ranges from 0 and 1 , reflects how suitable a land is for farming based on soil quality and climate. This variable is used as a robustness check. The data are taken from Ramankutty, Foley, et al. (2002). 


\section{Baseline geographic controls}

Ruggedness. The calculation for ruggedness takes a point on the earth's surface and measures the difference in elevation between this point and each of the eight major directions of the compass (north, northeast, east, southeast, south, southwest, west, and northwest). The index at the central point is given by the square root of the sum of the squared differences in elevation between the central point and the eight adjacent points (source: Nunn and Puga (2012)).

Distance to waterways. The distance, in thousands of km, from a GIS grid cell to the nearest ice-free coastline or sea-navigable river, averaged across the grid cells of a country (source: Harvard University's CID Research Datasets on General Measures of Geography).

Elevation. The average elevation of a country, in thousands of kilometers above sea level, calculated using geospatial data at a 1-degree resolution from the Geographically based Economic data (G-ECON) project.

Landlockedness. This dummy variable indicates whether a country is landlocked or not (source: Global Development Network Growth Database).

Latitude. The absolute value of latitude of a country's centroid.

Navigational distance. Distance between Camaret-sur-mer and the nearest port of historical significance in each country (source: Ertan, Fiszbein and Putterman (2016)).

Variation in elevation: This measure indicates standard deviation of elevation within country (source: Michalopoulos (2012)).

\section{Other controls}

Biogeography. The first principal component of the standardized numbers of domesticable wild plants and animals (source: Olsson and Hibbs (2005)). 
Early Disease Environment. The annualized probability of death for European males in the age cohort of soldiers (source: Ertan, Fiszbein and Putterman (2016)).

Duration of human settlement. The historical duration of human settlement (in million years) (source: Ahlerup and Olsson (2012)).

Mean land quality (soil-based): This variable measures the average agricultural suitability of land across regions based on soil properties (source: Michalopoulos, 2012).

Population density in 1500 AD (log). The population in 1500 AD divided by land area (source: McEvedy and Jones (1978); World Development Indicators, 2012).

Precipitation. The average precipitation of a country, in a unit of 10 millimeters per month over the period from 1961-1990, calculated using geospatial data at a 1-degree resolution from the Goegraphically based Economic data (G-ECON) project.

State history up to $1500 \mathrm{AD}$. An index of state history covering the period from $1 \mathrm{AD}$ to $1500 \mathrm{AD}$, scaled to take values between 0 and 1 . The dataset was originally introduced by Bockstette et al. (2002), but the current paper uses its latest version, v3.1. (source: Chanda, Cook and Putterman (2014)).

Temperature. The average temperature of a country, in a unit of 10 degree Celsius per month over the period from 1961-1990, calculated using geospatial data at a 1-degree resolution from the Geographically based Economic data (G-ECON) project.

Proportion of water area. Total surface of all inland water bodies (including lakes, reservoirs, and rivers) as a fraction of the total land area (source: CIA's The World Factbook. Available at https://www.cia.gov/library/publications/the-worldfactbook/fields/2147.html)

Years since agricultural transition. The number of years elapsed, in $2000 \mathrm{AD}$, since the transition to agriculture was estimated to occur (in thousand years) (source: 
Putterman (2006)).

\section{Categorization of levels of input used to compile crop yield}

In their natural state, many soils, in particular in the tropics, cannot be continuously cultivated without undergoing degradation. Such degradation is marked by a decrease in crop yields and a deterioration of soil structure; nutrient status; and other physical, chemical, and biological attributes. Under traditional low input farming systems, this deterioration is kept in check by alternating some years of cultivation with periods of fallow. Regeneration of nutrients and maintenance of soil fertility under low input cultivation is achieved through natural bush or grass fallow. At somewhat higher inputs to soils, soil fertility is maintained through fallow that may include for a portion of time a grass, grass-legume ley, or a green-manure crop. The high level assumes the best farming technology, soil nutrient inputs, and management known today.

With balanced fertilizer applications and proper pest and disease management (which is best possible at high level of inputs), only limited fallow will be required to maintain soil fertility and to keep pest and disease outbreaks in check. At low level of inputs - assuming virtually no application of chemicals and only limited organic fertilizer, and very limited or no application of biocides - there is a need for considerable fallow periods in the crop rotations to restore soil nutrient status and to break pest and disease cycles. The expected longterm yields as estimated by the GAEZ procedures assume that proper crop/fallow

As a rule of thumb for low level input/management conditions, fallow period requirements may vary between $30-90 \%$ of the cultivation fallow cycle. At high 
levels of inputs and management, fallow requirements are uniformly set at $10 \%$. At intermediate level of inputs, the fallow requirements are set at one third of the levels required under low level of inputs.

On average, long-term achievable yields are 10\%, 20\%, and 55\% lower than maximum attainable yields, at high, intermediate, and low levels of inputs, respectively. 


\section{The Long-run Effects of Agriculture Productivity on Democracy}

\subsection{Introduction}

Recent literature has established that history matters in economic growth. It can explain variation in the quality of institutions, differences in cultural values, and divergence in economic development across countries (e.g.Acemoglu, Johnson and Robinson (2001); Tabellini (2010); Alesina, Giuliano and Nunn (2013)). The transformation of preindustrial agrarian societies to modern democracies has been a long process. Democracy is one of the most important institutions that is argued to accelerate economic growth (Acemoglu, Naidu et al. (2014)) and affects various other development indicators such as health (See, Besley and Kudamatsu (2006)). However, what promotes democracy, and why democracy stabilizes in some countries and not others, is not yet very clear.

Many philosophers have tried to explain the conditions that may promote democracy. For example, the modernization theory posed by Lipset (1959) argues that there is a certain set of social requisites - such as wealth, measured by economic development, industrialization, urbanization, and education - that promote democracy. Others argue that the roots of democracies lie in the spread of protestant missionary (e.g., Woodberry (2012)). But, existing literature has largely agreed on a positive association between economic prosperity and current level of democracy (e.g. Barro (1999); Barro (2015)). Current economic prosperity is an outcome of complex historic events that happened in the past. Recent empirical literature has established that historical events persist in influencing the contemporary economic development of nations in numerous ways. 
This includes natural endowments such as the geographical and biological characteristics that must have influenced the path of development in the past whether it is initial biogeographic endowment and transition to agriculture (e.g. Olsson and Hibbs (2005); Hibbs and Olsson (2004); Galor and Moav (2007)) or past technology adoption (Comin et al. 2006, 2009). An early and productive start is expected to have a positive association with current economic prosperity and the quality of institutions. Agricultural produce became the main source of food supply and employment after the invention of sedentary farming practices. Societies developed traditions and norms while participating in agriculture practices (e.g. Alesina, Giuliano and Nunn (2013); Galor and Özak (2016); Olsson and Paik (2016)). For example, Alesina, Giuliano and Nunn (2013) argues that the use of heavy plough in agriculture, which requires higher upper body strength, segregated the roles of male and female in the society. They further show the persistence of gender roles using contemporary female labor force participation. Galor and Özak (2016) concentrate on the kind of crops indigenous people cultivated in the past. Their results show that the people who grew crops that had higher return on investment cultivated a habit of long-term orientation over time, which persists in these societies. Likewise, Olsson and Paik (2016) establish that early advent of farming practices developed a culture of collectivism as more individualist people moved away from the core towards peripheries. They further provide evidence that the divergence in attitude that developed during early agriculture practices still persist.

However, there have not been any studies that explore the influence of land productivity over the development of political regimes. Further, assuming a linear relation is too simplistic an examination of the link between the present and the past. Recent literature has revealed a non-linear association between events in the distant 
past and present economic development. For example, Ashraf and Galor (2013) argue that predicted genetic diversity has a hump-shaped association with contemporary economic development, such as per capita income in 2000. In a similar vein, Borcan, Olsson and Putterman (2016) find that the state history since 3500 BCE and economic development have a hump-shaped association.

Taking this line of research forward, we propose that the agricultural productivity, measured by the potential crop yield, can explain the cross-country variation in the level of democracy. The idea that land endowment has an impact on the kind of institutions developed in different countries has been explored previously. Engerman and Sokoloff (1997) and Sokoloff and Engerman (2000) (henceforth ES) document the differences in land endowment in Latin America and North America. Consistent with Lipset's (1959) modernization theory, at low levels of agricultural productivity the associated poverty yields autocracy. However, as land productivity and income rise, the degree of democracy gradually increases. The middle range of agricultural productivity tends to yield independent (often cereal producing) family farms with a more equal distribution of income and democratic traditions (Engerman and Sokoloff, 2000, 2005). However, at sufficiently high levels of productivity, land becomes suitable for plantation crops (such as bananas, cocoa, and sugar), and conditions become favorable for slavery and rent-seeking (Engerman and Sokoloff, 1997, 2000, 2005; Easterly, 2007). The resulting distributions of economic and political powers have persisted until today. The literature on the resource curse similarly argues that point source resources, which are spatially concentrated, high value, and easily monitored and controlled, often yield conditions unfavorable to democracy (see, e.g., Auty, 2001; Bulte et al., 2005; Isham et al., 2005; Bentzen et al.'s, 2017). We argue that high productivity agriculture is a point source resource, which has resulted in a 
resource curse similar to oil and minerals. This yields the downward sloping portion of our hypothesized hump-shaped (inverted U) relationship between land productivity and democracy.

Table 1A: Bottom and top decile countries by crop yield in the sample

\begin{tabular}{|c|c|c|c|c|}
\hline \multirow[b]{2}{*}{ Continent } & \multicolumn{2}{|c|}{ Bottom Decile } & \multicolumn{2}{|c|}{ Top Decile } \\
\hline & $\begin{array}{l}\text { Country (Crop } \\
\text { yield) }\end{array}$ & $\begin{array}{l}\text { Polity2 (1961- } \\
\text { 2015) }\end{array}$ & Country (Crop yield) & $\begin{array}{l}\text { Polity2 (1961- } \\
\text { 2015) }\end{array}$ \\
\hline Africa & $\begin{array}{l}\text { Egypt (36) } \\
\text { Djibouti (70) } \\
\text { Libya (323) } \\
\text { Mauritania (425) } \\
\text { Algeria (512) }\end{array}$ & $\begin{array}{l}-6 \\
-3 \\
-6 \\
-6 \\
-5\end{array}$ & $\begin{array}{l}\text { Madagascar (11475) } \\
\text { Swaziland (11661) } \\
\text { Benin (11914) } \\
\text { Tanzania (12150) } \\
\text { Mozambique (12223) } \\
\text { Malawi (12241) } \\
\text { Guinea-Bissau } \\
\text { (12331) } \\
\text { Zambia (12339) }\end{array}$ & $\begin{array}{l}1 \\
-8 \\
0 \\
-4 \\
-1 \\
-3 \\
-1 \\
-1\end{array}$ \\
\hline Asia & $\begin{array}{l}\text { Yemen (0) } \\
\text { Bahrain (0) } \\
\text { Qatar (0) } \\
\text { Saudi Arabia (6) } \\
\text { Kuwait (23) } \\
\text { Oman (59) } \\
\text { UAE (63) } \\
\text { Mongolia (597) } \\
\text { Jordon (880) }\end{array}$ & $\begin{array}{c}-2 \\
-9 \\
-10 \\
-10 \\
-8 \\
-9 \\
-8 \\
1 \\
-6\end{array}$ & $\begin{array}{l}\text { Korea, Republic } \\
\text { (14018) }\end{array}$ & 2 \\
\hline Europe & Norway (908) & 10 & Hungary (11743) & 1 \\
\hline $\begin{array}{l}\text { North } \\
\text { America }\end{array}$ & & & $\begin{array}{l}\text { Cuba (11848) } \\
\text { Dominican Republic } \\
(12071) \\
\text { Haiti (12339) }\end{array}$ & $\begin{array}{l}-7 \\
4 \\
-4\end{array}$ \\
\hline $\begin{array}{l}\text { South } \\
\text { America }\end{array}$ & & & Paraguay (12856) & -1 \\
\hline
\end{tabular}

In a similar vein, Diamond (1997) argued that the societies with a higher endowment

of grains species, and with resistance to germs, led technological advancement and this divergence still persists. Our hypothesis is further supported by simple observation of the top and bottom decile of the countries categorized by their respective potential crop yield. None of the countries in the bottom decile countries are a democracy, except Norway. All of these non-democracies are situated in either 
Asia or Africa. Similarly, the top decile countries are also either non-democracies or have very low levels of democracy (average polity2 score over 1961-2015). Most of these countries are again situated in either Asia or Africa. A few of these are located in the Americas and Europe as well. Intriguingly, Western European countries colonized most of these countries in the past. We will return to the colonial experience again.

We hypothesized an inverted-U shaped association between the agricultural productivity and the extent of democracy. In simple form, the positive effect of agricultural productivity on the level of democracy dominates at lower level and the association reverses at a higher level. Potential crop yield captures maximum potential crop yield (measured in millions of kilocalories per hectare per year) across different regions in a country. Crop yield index is constructed using crop yield (measured in tons per hectare per year) from Global Agro-Ecological Zones (GAEZ) project of the Food and Agriculture Organization (FAO) and caloric content of various crops from the US Department of Agriculture Nutrient Database for Standard Reference. This data is generously provided by Galor and Özak (2016). More details on the construction of the variable are discussed in the data section.

However, as proposed by our hypothesis, a humped shaped relationship between potential crop yield and the level of democracy can exist if we can identify two competing effects of potential crop yield on the level of democracy. As we discussed earlier, there is a wide range of literature that suggests a positive association between the level of democracy and economic prosperity, including Lipset (1959). The key assumption behind this positive association is that all members of a society will be taxed and then the state will provide public goods. This assumption holds true if the size of middle class or the suffrage is large, because the survival of rulers depends on 
the masses.

However, we also argue that beyond a certain point, agricultural land productivity has a negative effect on democracy. To make this point, we rely on the literature that argues that point source resources of high value, which are easily monitored and controlled, often yield conditions unfavorable to democracy (see, e.g., Auty, 2001; Bulte et al., 2005; Isham et al., 2005; Bentzen et al.'s, 2017). Thus, as agricultural productivity reaches the highest levels, land becomes a point source resource and a resource curse emerges. Agricultural production turns to plantation crops such as bananas, cocoa, and sugar, and intense rent-seeking and slavery becomes more likely (Engerman and Sokoloff, 2000, 2005; Easterly, 2007; Lagerlöf, 2009; Fenske, 2013), leading to a higher likelihood of autocracy today.

Isham et al. (2005) list numerous resource curse effects, including a reduced need for administrative capacity when the pressure for taxation of the general population is lower given a revenue target, which in turn yields a lower demand for government accountability. With higher revenues, the government can more easily bribe potential dissenters, or use violent repression against them. Moreover, the land-owning elite has resisted industrialization and associated modernization (urbanization, education, and occupational specialization) as this would dilute their economic and political power. Bentzen et al. (2017) argue that a history of irrigation-based agriculture has created a resource curse. Democracy was hampered by rent-seeking by economic and political elites who controlled the use of water. These elites have been unwilling to allow democracy to develop. We argue that highly productive land has similarly resulted in economic and political rent-seeking by land-owning elites in a pattern consistent with the resource curse, with autocracy as a political outcome. 
Johnson and Earle (2000: chapter 9) also discuss the possible negative influence of high agricultural productivity on society. According to them, an abundance of food because of high agricultural productivity may create aggrandizers ${ }^{28}$ who want to dominate the rest of the society's members. The elites and state can emerge and survive only when there are enough resources to support them. Elites collect taxes from the masses and may either redistribute surplus food among the masses or appropriate it for their own benefit. Other possibility to explain the negative influence can be high correlation between the crop yield and early development, measured by urbanization, as argued by Acemoglu, Johnson and Robinson (2001, 2002). The places that experienced early development could successfully resist direct rule by the European colonization (Hariri, 2012), continue authoritarian rule, and this led to reversal of fortune as argued by these authors.

Coming back to the colonial experience, the colonizers wanted to extract maximum rent from plantation economies in these highly productive regions. The economic importance of these highly productive regions for sugar plantation is apparent from two events. In the Treaty of Breda (1667), the Dutch ceded their claim to New Netherland (New York) and exchanged it for Suriname in South America. In another event, the French wanted to keep their sugar plantation in Guadeloupe in exchange for large territories in Canada (Parker (2011) p138, p305).

With the intensification of agriculture, elites also develop highly productive agricultural facilities such as irrigation systems, terraces, and drainage. Elites can extract rent from improved lands that become their property after improvement. Johnson and Earle (2000), says such mechanism supported the higher stratification of

${ }^{28}$ Ambitious and greedy individuals 
Hawaii and the Inca empire. In a recent paper, Bentzen, Kaarsen and Wingender (2016) have used potential of irrigation in a region as proxy to measure the probability of concentration of power to explain variation in autocracy across countries.

Building on previous literature, this study contributes additional knowledge about the influence of agricultural productivity, measured by potential crop yield, on contemporary levels of democracy across countries. We establish that the humpshaped influence of crop yield on democracy withstands the inclusion of various potentially confounding controls, such as measures of early development, measures of contemporary development, institutions, social cleavages, European influence, migration, human capital, and other geographical factors that have been identified to influence democracy in empirical studies on cross-country comparative development. We also find evidence that the hump-shaped association between crop yield and democracy existed in the pre-colonial era as well.

The rest of the paper is organized as follows: Section 4.2 presents regression model and data description. Section 4.3 reports regression analysis and findings of various robustness results. Section 4.4 concludes.

\subsection{Empirical Approach and Data}

\subsubsection{Regression Model}

We estimate the following regression model to evaluate the influence of potential crop yield on the extent of democracy:

$$
\text { democracy }_{i}=\beta_{0}+\beta_{1} \text { cropyield }_{i}+\beta_{2} \text { cropyield }_{i}^{2}+\beta_{3} \text { Controls }_{i}+\epsilon_{i}
$$

where democracy $y_{i}$ is the average of democracy over the period of study for country $\mathrm{i}$, cropyield $_{i}$ is potential crop yield in country $i$, and Controls $s_{i}$ is a vector of control 
variables included in the regression to minimize the possibility of getting spurious estimates, and $\epsilon_{i}$ is country-specific error term.

Equation (1) represents reduced-form model specification of influence of potential crop yield on the extent of democracy. As hypothesized earlier, potential crop yield has a hump-shaped influence on level of democracy through two competing influences on the extent of democracy - a positive influence through development of social infrastructure, and negative influence through concentration of power. Specifically, we expect both, $\beta_{1}$ and $\beta_{2}$, to be statistically significant, and have positive and negative sign, respectively. Our baseline sample used in the crosscountry analysis consists of data for up to 147 countries.

\subsubsection{Data}

\section{A. Outcome measures}

The dependent variables such as polity2, democ, autoc, and similar are constructed using data over the period 1961-2015. We focus on post-1960 period as most of the former European colonies in Sub-Saharan Africa, Middle East, South and East Asia gained independence by then. This let us explore the political regime with minimum possibility that the results are confounded by colonial powers directly influencing the domestic institutions in former colonies. However, we tested our model with alternative periods spanning since 1800 for robustness.

POLITY2: Data is taken from Polity IV project, Political Regime Characteristics and Transitions, 1800-2015 (Marshall, Gurr and Jaggers (2015)). This provides an annual score of political regime authority characteristics for all independent countries with total population greater than half a million in 2015 (167 in total). The project examines concomitant qualities of democratic and autocratic authority in governing 
institutions, rather than discreet and mutually exclusive forms of governance. This perspective envisions a spectrum of governing authority that spans from fully institutionalized autocracies through mixed, or incoherent, authority regimes (termed "anocracies") to fully institutionalized democracies.

The Polity score is based on the coding of six component measures that record salient features about executive recruitment process, constraints on executive authority and political competition. It also records changes in the institutionalized qualities of governing authority. The "Polity Score" captures the regime authority on a 21-point scale ranging from -10 (hereditary monarchy) to +10 (consolidated democracy). We have also used democratic (polity2 greater than 5) and autocratic (polity2<-5) categorizations suggested by Polity IV projects as robustness checks.

DEMOC and AUTOC: These indices are from the Polity IV project as well. They reflect the degree of institutionalized democracy and institutionalized autocracy, respectively. The variables are measured on a scale of 0 to 10 , where 10 indicates the largest degree of democracy or autocracy for respective variable (source: Marshall, Gurr and Jaggers (2015)).

We also use measures of democracy or related concept from other sources such as civil liberties and political rights from Freedom House (2016). We will discuss them in detail when we use them later.

\section{B. Independent variable (crop yield)}

As discussed earlier, our independent variable is potential crop yield for respective geographical entities. This index captures potential crop yield (measured in millions of kilocalories per hectare per year) across different regions at the unit of analysis level. It addresses the limitations of other available weight-based agricultural yield indices. For example, the land productivity index constructed by Ramankutty, Foley 
et al. (2002), does not reflect the fact that equally suitable land can have a large variation in crop yield since caloric-intensive crops may not be cultivated in some regions (see Galor and Özak (2015)).

The data on potential crop yield are taken from Galor and Özak (2016), who construct their dataset from the Global Agro-Ecological Zones (GAEZ) project of the Food and Agriculture Organization (FAO). GAEZ supplies global yield and growth cycle estimates for 48 crops in grids with cells size of 5' $\times 5$ ' (approximately $100 \mathrm{~km}^{2}$ ). ${ }^{29}$ GAEZ supplies crop yield estimates for each crop based on three alternative levels of input - high, medium and low - and two feasible sources of water supply - rain-fed water supply and irrigation. The FAO dataset supplies potential yield estimates for each crop in each agro-climatic grid while accounting for the effect of temperature and moisture on the growth of the crop.

The crop yield index is constructed using a low level of inputs and rain-fed agriculture cultivation methods in order to account for the agricultural conditions that were prevalent during the pre-industrial era. This reflects farming practices prevalent during the early stages of development. Furthermore, the crop yield data are based on agro-climatic conditions that are independent of any human intervention. This, therefore, mitigates any potential endogeneity pertaining to agricultural inputs, irrigation method, and soil quality.

Each crop yield in the GAEZ data (measured in tons per hectare per year) is converted by Galor and Özak (2016) into caloric yield (millions of kilocalories per

\footnotetext{
29 These 48 crops are alfalfa, banana, barley, buckwheat, cabbage, cacao, carrot, cassava, chickpea, citrus, coconut, coffee, cotton, cowpea, dry pea, flax, foxtail millet, green gram, groundnuts, indigo rice, maize, oat, oil palm, olive, onion, palm heart, pearl millet, phaseolus bean, pigeon pea, rye, sorghum, soybean, sunflower, sweet potato, tea, tomato, wetland rice, wheat, spring wheat, winter wheat, white potato, yams, giant yams, subtropical sorghum, tropical highland sorghum, tropical lowland sorghum, white yams.
} 
hectare per year) to represent the nutritional variation across crops and to compare crop yields among different crops. The US Department of Agriculture Nutrient Database for Standard Reference provides data on the caloric content of various crops. Using these measures, the estimated average regional crop yield reflects the average regional levels of two variables - crop yield and crop cycle - among crops that maximize the caloric yield in each cell. Our analysis focuses on the averages across cells where the maximum potential crop yield is positive.

Figure 4-1 shows potential crop yield, measured as millions of kilocalories per hectare per year, and extent of democracy, measured by average polity 2 score over period 1960-2015. The bottom decile of countries has a crop yield below 907, while the top decile has a variation of over 11474 (Table 1A). 
Figure 4-1 Distribution of democracy and potential crop yield across 147 countries
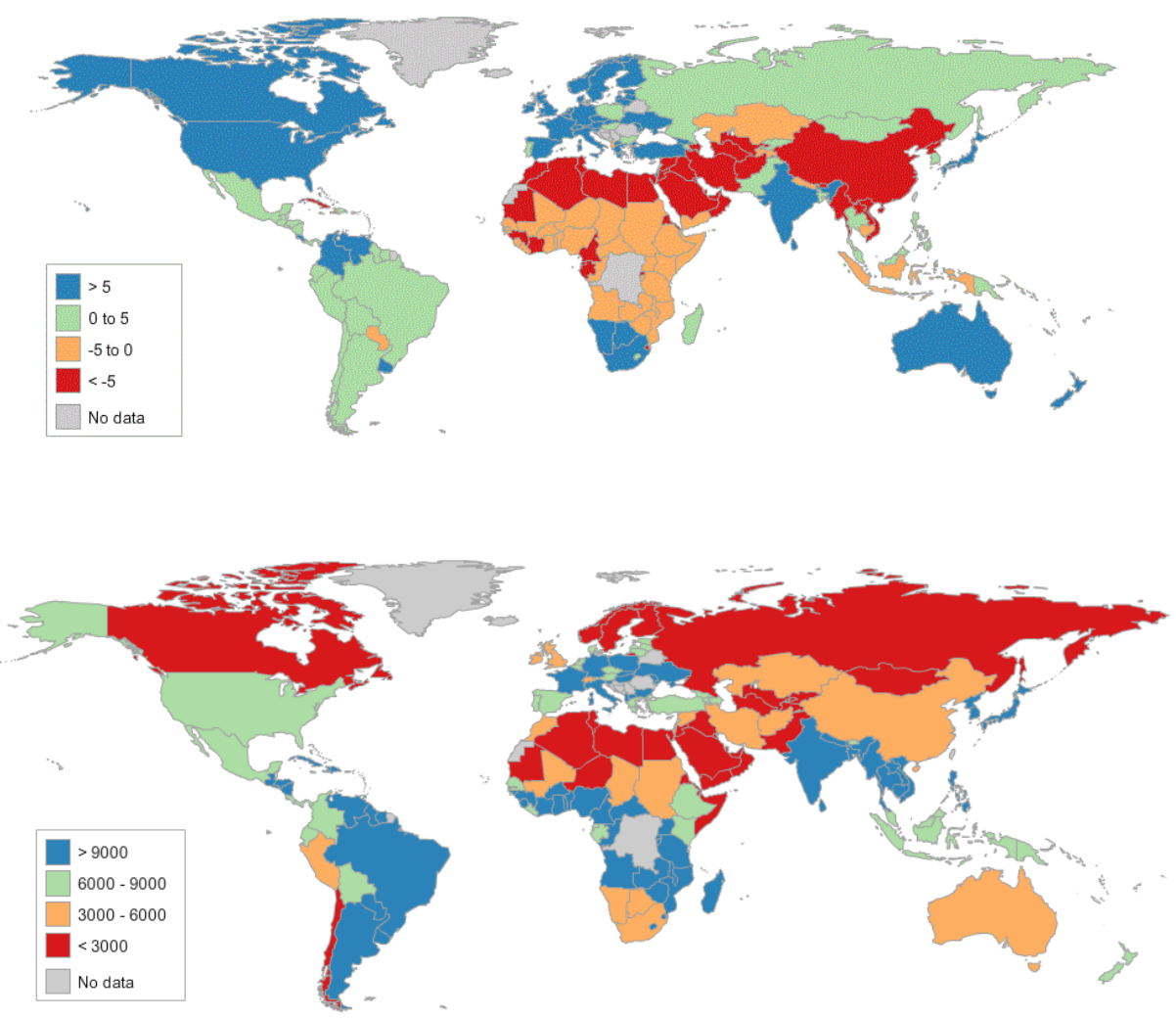

Notes: Top panel shows the democracy, measured as average of POLITY2 score over 1961-2015, and the bottom panel shows potential crop yield (measured in millions of calories per year per hectare).

\section{Control variables}

Several control variables which may potentially confound the association between crop yield and the extent of democracy are accounted for in the regressions. This includes terrain ruggedness, absolute latitude, elevation, difference in elevation, distance to nearest waterway, and landlockedness. We also include continent dummies to account for any omitted variable bias of time-invariant continent-specific geographical, cultural, and historical characteristics. Summary statistics and the correlations of the variables are given in Table 1B. 
Table 1B: Summary statistics and correlation

\begin{tabular}{lccccc}
\hline & $\begin{array}{c}\text { Number of } \\
\text { observations }\end{array}$ & Mean & $\begin{array}{c}\text { Standard } \\
\text { deviation }\end{array}$ & Minimum & Maximum \\
\hline Polity2 (1961-2015) & 148 & 0.8 & 6.1 & -10.0 & 10.0 \\
Crop yield & 148 & 7335 & 3905 & 0.0 & 17998 \\
Absolute latitude & 148 & 26.6 & 16.9 & 1.0 & 64.0 \\
Terrain ruggedness & 148 & 1.3 & 1.2 & 0.0 & 6.7 \\
Landlocked & 148 & 0.2 & 0.4 & 0.0 & 1.0 \\
Elevation (average) & 148 & 0.6 & 0.5 & 0.0 & 2.7 \\
Elevation (variation) & 148 & 0.4 & 0.4 & 0.0 & 1.9 \\
Distance to & 148 & 0.4 & 0.4 & 0.0 & 2.2 \\
waterways & & & & & \\
\hline
\end{tabular}

\begin{tabular}{lrrrrrrrr}
\hline & \multicolumn{1}{c}{ (1) } & (2) & (3) & (4) & (5) & (6) & (7) & (8) \\
\hline (1) Polity2 (1961-2015) & 1 & & & & & & & \\
(2) Crop yield & 0.32 & 1 & & & & & & \\
(3) Absolute latitude & 0.33 & -0.23 & 1 & & & & & \\
(4) Terrain ruggedness & 0.01 & -0.01 & 0.15 & 1 & & & & \\
(5) Landlocked & -0.09 & 0.05 & 0.1 & 0.27 & 1 & & & \\
(6) Elevation (average) & -0.15 & -0.1 & -0.02 & 0.71 & 0.48 & 1 & & \\
(7) Elevation (variation) & -0.06 & -0.11 & -0.01 & 0.57 & 0.14 & 0.74 & 1 & \\
(8) Distance to waterways & -0.21 & -0.26 & 0.11 & -0.02 & 0.57 & 0.42 & 0.23 & 1 \\
\hline
\end{tabular}

Notes: This table presents summary statistics and correlations of variables used in baseline estimation.

\subsection{Empirical Results}

\subsubsection{Cross-Country Analysis}

Table 4-1 presents our findings for influence of crop yield on the extent of democracy, measured by average polity 2 score over the period 1961-2015. Column (1) reports simple association between extent of democracy and potential crop yield, which is positive and significant. We add crop yield square along with linear potential crop yield. The results displayed in column (2) indicate a concave association, $\beta_{1}$ is positive and $\beta_{2}$ is negative, between extent of democracy and potential crop yield. The quadratic pattern fits the data better as both linear and quadratic terms are statistically significant and the value of adjusted $R^{2}$ has also increased. However, a quadratic relation may not necessarily represent a hump-shaped (non-monotonic) relationship between the variables considered. We use "two-line" approach suggested by Simonsohn (2016) to address this concern. Accordingly, we estimate linear 
relationship between extent of democracy and below and above the democracymaximizing potential crop yield (which is 7,032 million kilocalories per hectare per year). Two linear estimations in Figure 4-3 show that there is indeed a statistical significant hump-shaped relationship between extent of democracy and potential crop yield.

Table 4-1 Crop yield on democracy after accounting for geographical controls

\begin{tabular}{|c|c|c|c|c|c|}
\hline \multirow[b]{2}{*}{ Dependent variable } & (1) & (2) & (3) & (4) & $\begin{array}{c}(5) \\
\text { (Baseline) }\end{array}$ \\
\hline & \multicolumn{5}{|c|}{ polity2 (1961-2015) } \\
\hline \multirow[t]{2}{*}{ Crop yield } & $0.20 * *$ & $1.64 * * *$ & $1.45 * * *$ & $1.48 * * *$ & $1.04 * * *$ \\
\hline & $(2.58)$ & $(6.33)$ & $(6.72)$ & $(6.54)$ & $(4.05)$ \\
\hline \multirow[t]{2}{*}{ Crop yield square } & & $-1.49 * * *$ & $-1.17 * * *$ & $-1.24 * * *$ & $-0.91 * * *$ \\
\hline & & $(-5.60)$ & $(-5.22)$ & $(-5.39)$ & $(-3.46)$ \\
\hline \multirow[t]{2}{*}{ Absolute latitude } & & & $0.46 * * *$ & $0.48 * * *$ & $0.27 * *$ \\
\hline & & & $(7.22)$ & $(7.40)$ & $(2.06)$ \\
\hline \multirow[t]{2}{*}{ Terrain ruggedness } & & & & -0.08 & -0.05 \\
\hline & & & & $(-0.68)$ & $(-0.47)$ \\
\hline \multirow[t]{2}{*}{ Elevation (average) } & & & & -0.03 & 0.20 \\
\hline & & & & $(-0.18)$ & $(1.41)$ \\
\hline \multirow[t]{2}{*}{ Elevation (std dev.) } & & & & -0.00 & -0.17 \\
\hline & & & & $(-0.00)$ & $(-1.58)$ \\
\hline \multirow[t]{2}{*}{ Landlocked } & & & & -0.05 & -0.08 \\
\hline & & & & $(-0.53)$ & $(-1.10)$ \\
\hline \multirow[t]{2}{*}{ Distance to waterways } & & & & -0.15 & -0.09 \\
\hline & & & & $(-1.47)$ & $(-1.22)$ \\
\hline \multirow[t]{2}{*}{ Optimum crop yield } & - & 7.032 & 7.892 & 7.625 & 7.286 \\
\hline & - & 0.353 & 0.507 & 0.461 & 0.633 \\
\hline Observations & 147 & 147 & 147 & 147 & 147 \\
\hline Adj R-squared & 0.04 & 0.18 & 0.37 & 0.40 & 0.54 \\
\hline Continent dummies & No & No & No & No & Yes \\
\hline
\end{tabular}

Notes: This table presents standardized coefficients for the effect of average crop yield (measured in billions of kilocalories per hectare per year) on polity2 score over period 1961-2015. All specifications use an intercept term but not reported for brevity. The continent dummies are Africa, Asia, Australia, Europe, North America, Oceana, and South America. Robust t-statistics are given in parentheses. ***, $* *, *$ denotes significance at the $1 \%, 5 \%$, and $10 \%$ level, respectively.

Progressively, we include more geographical control variables in column (3) through (5). Latitude captures climatic effects. Low latitudes are associated with poor soil quality, highly variable rainfall, and a high incidence of debilitating tropical disease (Olsson and Hibbs (2005)).We include absolute latitude in our specification in column (3). We find that influence of crop yield on democracy remains intact and 
absolute latitude is complementary to crop yield in explaining the extent of democracy. Further, our results remain robust to the inclusion of more geographical controls - terrain ruggedness, average elevation, elevation variation, landlockedness, and distance to waterways - in column (4). Then, we account for continent fixed effect in column (5) to account for any continent specific time-invariant fixed effect. We find that influence of coefficients of linear and quadratic crop yield remain robust and statistically significant at $1 \%$ level. Our specification in column (5) explains around $53.7 \%$ variation in democracy in cross-country analysis. We use column (5) as baseline estimation in robustness analysis in the following sections.

Lastly, our analysis in column (2) shows that the predicted democracy-maximizing level of potential crop yield may be reached at around 7,032 million of kilocalories per hectare per year.

Figure 4-2 Scattered plot of potential crop yield and democracy during 1961-2015

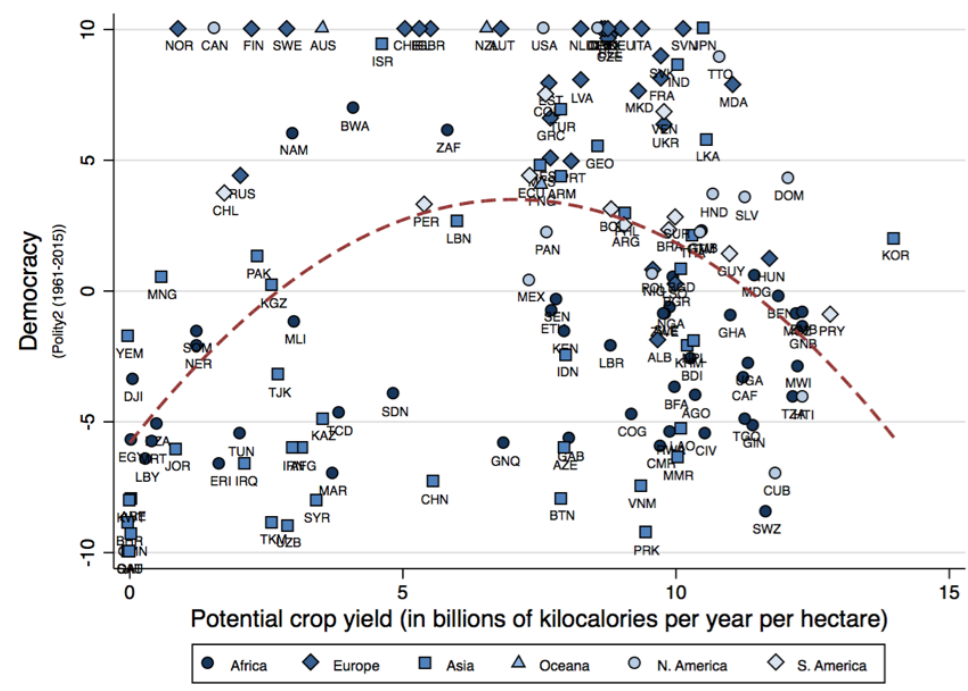

Notes: This scatter plot presents distribution of crop yield, measured in billions of kilocalories per year per hectare, and democracy, measured as average of polity2 score over 1961-2015. Uruguay is an outlier in the sample (Source: Galor and Özak (2016).

\subsubsection{Robustness to Alternative Measures of Democracy}

Democracy is a broad concept and there is no general consensus on a single measure 
that represents democracy for a country. However, Polity 2 score is the most widely used measure of democracy in economic literature. Following this common practice, we use average of Polity2 score over 1961-2015 as the main outcome variable in baseline estimations. There is a possibility that our results are influenced by the use of this particular measure over 1961-2015 period. To mitigate such concerns, we perform various sensitivity tests - such as, change threshold value to qualify as a democracy, change duration of study, and use measure of democracy from other sources.

Figure 4-3 Linear relationship of piece-wise potential crop yield and democracy during 1961-2015
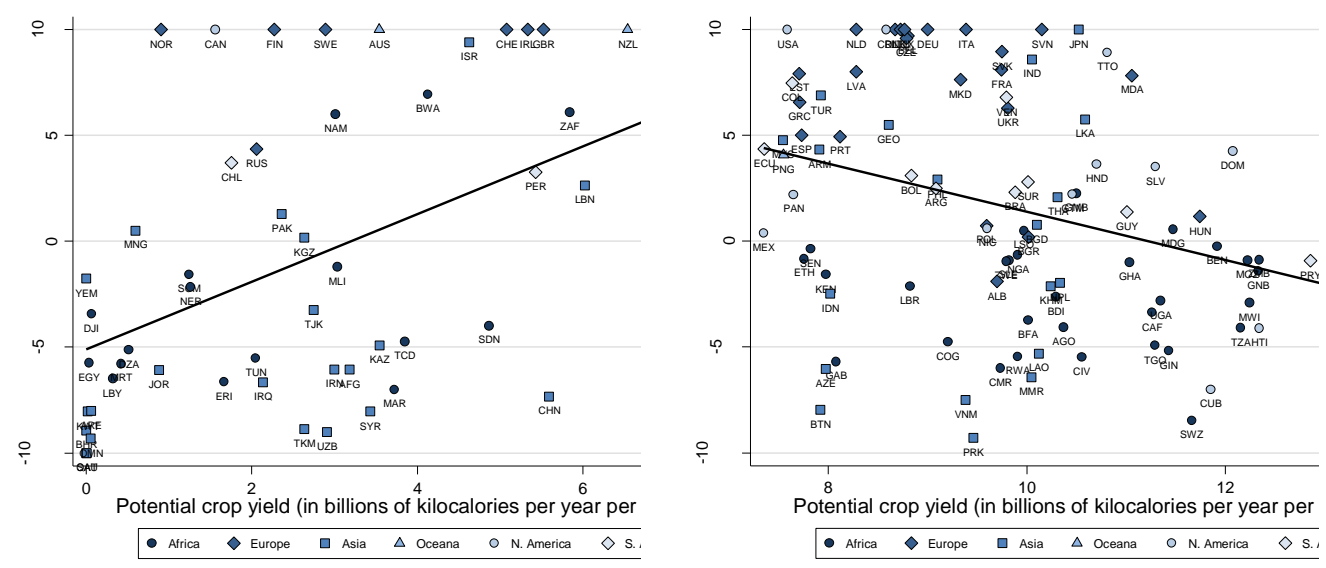

Coeff $=0.47$, se $($ robust $)=0.40, t=3.96$ Coeff $=-0.24$, se $($ robust $)=0.37, t=-2.04$

Notes: These figures present scattered plot of democracy, measured by average polity 2 score over 19612015 period, and potential crop yield. Total number of observations is 147 (left panel $=67$, right panel $=$ 80). Data have been split into two at the point of optimum crop yield for democracy in full sample. Figure in the left panel shows the positive linear association between crop yield and democracy. The linear association reverses for higher values of crop yield in right panel.

In Table 4-2, column (1) repeats our baseline estimation from Table 4-1 for easy comparison. The focus of the study is to examine long-run influence of the potential crop yield on the average level of democracy since 1961. However, many countries experience changes in the type of political regime they have over the years. There are 
two limitations in using the average of democracy. If we choose a very long period, we will miss lots of information from intermittent period. While a small period will be prone to short-term fluctuations in the measure of democracy. We overcome this challenge by varying the starting year for calculating average of democracy. First, we use entire available data on Polity 2 score for all countries available since 1800 . Our findings presented in column (2) indicate that the hump-shaped influence of crop yield on extent of democracy is robust. Both, positive and negative coefficients are significant at $1 \%$ level and they are qualitatively very similar to the coefficients presented for baseline specification in column (1). Though, there is around 50\% drop in the fitness of the model, but then, 34\% model fitness for a sample over two century is remarkable. We repeat similar analysis by varying the starting date of the sample to 1900, 1931, and $1991^{30}$. The results are reported in column (3) through (5). We find that the inverted-U shaped influence of crop yield on the extent of democracy survives in column (3) and (4). However, the coefficient of potential crop yield square, that is negative influence of crop yield on extent of democracy, has become insignificant in column (5). We interpret this as the influence of third wave of democratization, and the sudden adoption of democracy by a number of countries after the end of cold war.

Polity2 score is a composite score that may mask the quality of institutional democracy. To mitigate such concern we use measures of institutional democracy (i.e. democ) and institutional autocracy (i.e. autoc) from latest version of Polity IV dataset (Marshall, Gurr and Jaggers (2015)) in column (6) and (7), respectively. Democ score lies between 0 and 10, where a higher value indicates a higher level of

\footnotetext{
${ }^{30}$ At each regular interval of 30 years since 1900.
} 
institutional democracy. Similarly, an autoc score lies between 0 and 10, where a higher value indicates a higher level of institutional autocracy. We construct two binary outcome variables using these institutional measures. For each country, when democ (or autoc) score is larger than 5, we assign a value 1 for that year, otherwise 0 . Then, a simple mean over the period 1961-2015 indicates the probability of a country to have institutional democracy (or autocracy) in the period. The results in column (6) and (7) indicate that the coefficients of linear and square effects of potential crop yield are statistically significant.

Next, we construct a measure of democracy (or autocracy) using polity2 score. We assign a value of 1 when the polity 2 score for a country is higher than 5 for any year, otherwise 0. Then, a simple mean over the period 1961-2015 is calculated. This represents the probability of a country to have democracy in the period similar to column (6), but this is computed using polity2 score instead. A similar measure of autocracy is also constructed by using polity 2 score but the criterion is that the polity 2 score is below -5 . These two outcome measures are used in regression in column (8) and (9), respectively. We find that the hump-shaped influence of crop yield on extent of democracy remains intact. 
Table 4-2 Influence of crop yield on democracy (alternative measures of democracy and crop yield)

\begin{tabular}{|c|c|c|c|c|c|c|c|c|}
\hline & $(1)$ & (2) & (3) & (4) & $(5)$ & (6) & $(7)$ & $(8)$ \\
\hline $\begin{array}{l}\text { Dependent } \\
\text { variable } \\
\text { (Period) }\end{array}$ & $\begin{array}{l}\text { polity2 } \\
(1961- \\
2015)\end{array}$ & $\begin{array}{l}\text { polity2 } \\
(1800- \\
2015)\end{array}$ & $\begin{array}{l}\text { polity2 } \\
(1901- \\
2015)\end{array}$ & $\begin{array}{l}\text { polity2 } \\
(1931- \\
2015)\end{array}$ & $\begin{array}{l}\text { polity2 } \\
(1991- \\
2015)\end{array}$ & $\begin{array}{l}\text { democ } \\
\text { (prob) } \\
(1961- \\
2015) \\
\end{array}$ & $\begin{array}{l}\text { autoc } \\
\text { (prob) } \\
(1961- \\
2015) \\
\end{array}$ & $\begin{array}{c}\text { polity2>5 } \\
(1961- \\
2015)\end{array}$ \\
\hline Crop yield & $\begin{array}{l}1.04^{* * * *} \\
(4.05)\end{array}$ & $\begin{array}{l}1.04^{* * * *} \\
(3.65)\end{array}$ & $\begin{array}{l}1.01^{* * * *} \\
(3.77)\end{array}$ & $\begin{array}{l}1.03^{* * *} \\
(3.93)\end{array}$ & $\begin{array}{l}0.71^{* *} \\
(2.41)\end{array}$ & $\begin{array}{l}0.86^{* * *} \\
(3.83)\end{array}$ & $\begin{array}{l}1.03^{* * * *} \\
(-2.96)\end{array}$ & $\begin{array}{l}0.95^{* * *} \\
(4.17)\end{array}$ \\
\hline $\begin{array}{l}\text { Crop yield } \\
\text { square }\end{array}$ & $\begin{array}{l}-0.91^{* * * *} \\
(-3.46)\end{array}$ & $\begin{array}{l}-0.94^{* * * *} \\
(-3.17)\end{array}$ & $\begin{array}{l}-0.91^{* * *} \\
(-3.34)\end{array}$ & $\begin{array}{l}-0.92^{\text {**** }} \\
(-3.47)\end{array}$ & $\begin{array}{c}-0.48 \\
(-1.62)\end{array}$ & $\begin{array}{l}-0.79^{* * * *} \\
(-3.22)\end{array}$ & $\begin{array}{l}-0.86^{* *} \\
(2.53)\end{array}$ & $\begin{array}{l}-0.86^{* * *} \\
(-3.49)\end{array}$ \\
\hline Observations & 147 & 147 & 147 & 147 & 146 & 147 & 147 & 147 \\
\hline $\begin{array}{l}\text { Continent } \\
\text { dummies }\end{array}$ & Yes & Yes & Yes & Yes & Yes & Yes & Yes & Yes \\
\hline $\begin{array}{l}\text { Baseline } \\
\text { controls }\end{array}$ & Yes & Yes & Yes & Yes & Yes & Yes & Yes & Yes \\
\hline $\begin{array}{l}\text { Adj R- } \\
\text { squared }\end{array}$ & 0.54 & 0.36 & 0.46 & 0.46 & 0.49 & 0.55 & 0.36 & 0.55 \\
\hline $\begin{array}{l}\text { Dependent } \\
\text { variable } \\
\text { (Period) }\end{array}$ & $\begin{array}{c}(9) \\
\text { polity } 2<- \\
5 \\
(1961- \\
2015) \\
\end{array}$ & $\begin{array}{c}(10) \\
\text { freedom } \\
\text { house } \\
(1973- \\
2015) \\
\end{array}$ & $\begin{array}{c}(11) \\
\text { dem_bmr } \\
(1961- \\
2015)\end{array}$ & $\begin{array}{c}\text { (12) } \\
\text { dem_rev } \\
(1961- \\
2015)\end{array}$ & $\begin{array}{l}(13) \\
\text { checks } \\
(1961- \\
2015)\end{array}$ & $\begin{array}{c}(14) \\
\text { polity2 } \\
(1961- \\
2015)\end{array}$ & $\begin{array}{c}(15) \\
\text { polity2 } \\
(1961- \\
2015)\end{array}$ & $\begin{array}{c}(16) \\
\text { polity2 } \\
(1961- \\
2015)\end{array}$ \\
\hline Crop yield & $\begin{array}{l}1.01^{* * *} \\
(-2.92) \\
-0.84^{* *}\end{array}$ & $\begin{array}{c}0.55 * * * \\
(2.97) \\
-0.47 * *\end{array}$ & $\begin{array}{l}0.68^{* * * *} \\
(2.92) \\
-0.59^{* *}\end{array}$ & $\begin{array}{l}0.70^{* * * *} \\
(3.13) \\
-0.58^{* * *}\end{array}$ & $\begin{array}{l}0.56^{* * *} \\
(2.58) \\
-039^{*}\end{array}$ & $\begin{array}{c}0.80 * * * \\
(3.19) \\
-061 * *\end{array}$ & $\begin{array}{c}0.62 * * * \\
(2.88) \\
-0.57 * *\end{array}$ & $\begin{array}{c}0.49 * * * \\
(2.77) \\
-0.48 * * *\end{array}$ \\
\hline $\begin{array}{l}\text { Crop yield } \\
\text { square }\end{array}$ & $(2.49)$ & $(-2.42)$ & $(-2.31)$ & $(-2.49)$ & $(-1.72)$ & $(-2.42)$ & $(-2.55)$ & $(-2.83)$ \\
\hline Observations & 147 & 149 & 148 & 148 & 148 & 145 & 146 & 119 \\
\hline $\begin{array}{l}\text { Continent } \\
\text { dummies }\end{array}$ & Yes & Yes & Yes & Yes & Yes & Yes & Yes & Yes \\
\hline $\begin{array}{l}\text { Baseline } \\
\text { controls }\end{array}$ & Yes & Yes & Yes & Yes & Yes & Yes & Yes & Yes \\
\hline $\begin{array}{l}\text { Adj R- } \\
\text { squared }\end{array}$ & 0.35 & 0.590 & 0.60 & 0.60 & 0.48 & 0.52 & 0.51 & 0.51 \\
\hline
\end{tabular}

Notes: This table presents standardized coefficients of (mean) crop yield (measured in millions of kilocalories per hectare per year) on various measures of democracy using OLS regression. Dependent variable in column (1) to (5) is average polity2 score over various periods and subscores democ and autoc in column (6) and column (7), respectively. In column (6), dependent variable is probability of a country in a year to be democratic (democ $>5$ ) over period 1961-2015. In column (6), dependent variable is probability of a country in a year to be autocratic (autoc $>5$ ) over period 1961-2015. Dependent variables in column (7), (9), and (10) are transformed appropriately so that a higher value indicates higher value of democracy. Dependent variable in column (10) is average of civil liberties and political rights over period 1973-2015. Dependent variable in column (11) and (12) are alternative measures of democracy developed by Boix, Miller and Rosato (2012) and Cheibub, Gandhi and Vreeland (2010), respectively. Dependent variable in column (13) is number of checks on executive averaged over 1961-2015. Column (14) uses ancestry-adjusted crop yield and its square as independent variables. Independent variable in column (15) is soil suitability from Ramankutty, Foley, et al. (2002). Independent variable in column (16) is potential crop yield per capita in 1500. Baseline controls used are absolute latitude, terrain ruggedness, elevation (average), elevation (variation), landlockedness, distance to waterways. All specifications use an intercept term but not reported for brevity. Robust t-statistics are given in parentheses. ***,**,* denote significance at the $1 \%, 5 \%$, and $10 \%$ level, respectively. 
Now, we test our model specification against the alternative measures of democracy from other sources. Political rights and civil liberty are two key ingredients for democracy to exist. Freedom House (2016) provides measure for civil liberties and political rights for a large number of countries since 1973. Both these indices - civil liberties and political rights - are highly correlated, so we use mean of both indices over period 1973-2015 to indicate outcome variable in column (9).We transform the outcome variable so that a higher value indicates more democratic regime, which is a higher level of civil liberties and political rights. Findings in column (10) suggest that the hump-shaped influence of crop yield on extent of democracy, measured by civil liberties and political rights, survives in cross-country analysis.

Further, we use measure of the extent of democracy from three more sources. Boix, Miller and Rosato (2012) compile a dichotomous measure of democracy that defines a country as democratic if it satisfies conditions for both contestation and participation. Specifically, political leaders are chosen through free and fair elections, and value of suffrage is beyond a threshold level in a democracy. Cheibub, Gandhi and Vreeland (2010) focus on how the incumbent leaders are removed to compile a dichotomous measure of democracy. Lastly, we use institutional and electoral results data such as measures of checks and balances, constructed by Keefer (2012), as our another alternative measure of democracy. The results of these three measures of democracy are reported in columns (11) through (13). We notice that the potential crop yield and these alternative measures of democracy have inverted-U shaped associations. Coefficients of linear and square terms remain significant in all specifications.

Lastly, we use various alternative measures of land productivity to mitigate any concern that our results are driven by the choice of measure of land productivity. We 
argued earlier that crop yield and other geographical conditions of a region shaped the economic prosperity and cultural values and the social capital gained in the past persists till modern societies. But, there has been large cross-country migration since sixteenth century. This may influence the net social capital of current population residing inside present-day countries. To mitigate such concerns, we use ancestryadjusted potential crop yield to examine the influence of potential crop yield on the extent of democracy ${ }^{31}$.We find in column (14) that the inverted-U shaped association exists between ancestry-adjusted crop yield and the extent of democracy as well. Then, we use land suitability index developed by Ramankutty, Foley, et al. (2002). This index, ranges from 0 to 1 , tells how suitable a land, based on soil quality and climate, is for farming. The results in column (15) indicate that our results are intact to the change in measure of land productivity.

Finally, we look at an alternative measure of energy available to the occupants of a region. There is possibility that potential crop yield per person may also explain the relationship as it is the crop yield that per person commands is more important than the total crop yield available in a region. However, according to Malthusian theory, a higher level of crop yield per person should result in higher population density in future. Ignoring different thoughts, we use potential crop yield per person in column (16) and find that the hump-shaped relationship remains robust. So, we can say that identified association between the crop yield and the extent of democracy is independent of the choice of measures, and source of data for the crop yield and the extent of democracy.

\footnotetext{
${ }^{31}$ Ancestry-adjusted potential crop yield is constructed by using potential crop yield of the country of origin of immigrants and world migration matrix constructed by Putterman and Weil (2010).
} 


\subsubsection{Robustness to Institutions and Early Development}

In this section, we account for various institutions which developed centuries ago and other early development indicators that can possibly have confounding effect on the extent of democracy in contemporary world. Europeans setup many modern institutions in the colonies according the need of particular region and the type of association they had with these regions. Acemoglu, Johnson and Robinson (2001) argued that the local environment that affected the mortality of Europeans in respective regions had an influence on the kind of institutions they setup in former colonies. Taking this argument further they also established the persistence of these institutions and their influence on the contemporary economic development. We account for the effect of this potentially confounding historic event, whether a country was colonized or not, and further, we also account for different European colonizers. Column (1) in Table 4-3 reports the findings after accounting for the dummies for various colonizers - namely, Britain, France, Spain, Portugal, and other European colonizers - in our global sample. Our results suggest that the colonial history does not affect the hump-shaped influence of crop yield on the extent of democracy. There is a possibility that different colonizers influenced the formation of colonial institutions differently. To account for such possibility, we restrict our sample to the countries that were colonized by any of the western Europeans colonizers. Findings in column (2) indicate that the both, linear and square, coefficients of crop yield are statistically significant at $1 \%$ level. P-value $(=0.05)$ of Wald test of colonial history in column (2) suggests that the origin of the colonizers does have positive and significant effect on the average level of democracy over period 1961-2015 in former colonies. 
Legal rights of the citizens also indicate the quality of political regime. European colonizers setup modern legal system in the colonies and these colonies inherited alternative legal system after their independence from former colonizers. Legal system of these colonizing powers also served as role model for the countries that were never colonized. In this process, most of the legal systems around the world have origins in Europe. Various studies highlight the important role of legal origin of a country in financial development, labor market regulations, and economic growth (La Porta, Lopez-de-Silanes and Shleifer (2008)). We account for the confounding effect of legal origin in column (3). We find that there is no change in the humpshaped influence of potential crop yield on the extent of democracy after controlling for legal origin - namely, British common law, French civil law, German civil law, Scandinavian law, and socialist law. However, the p-value of Wald test suggests a strong influence of legal origin on the extent of democracy in cross country analysis. 
Table 4-3 Influence of crop yield on democracy after accounting for institutions and early development

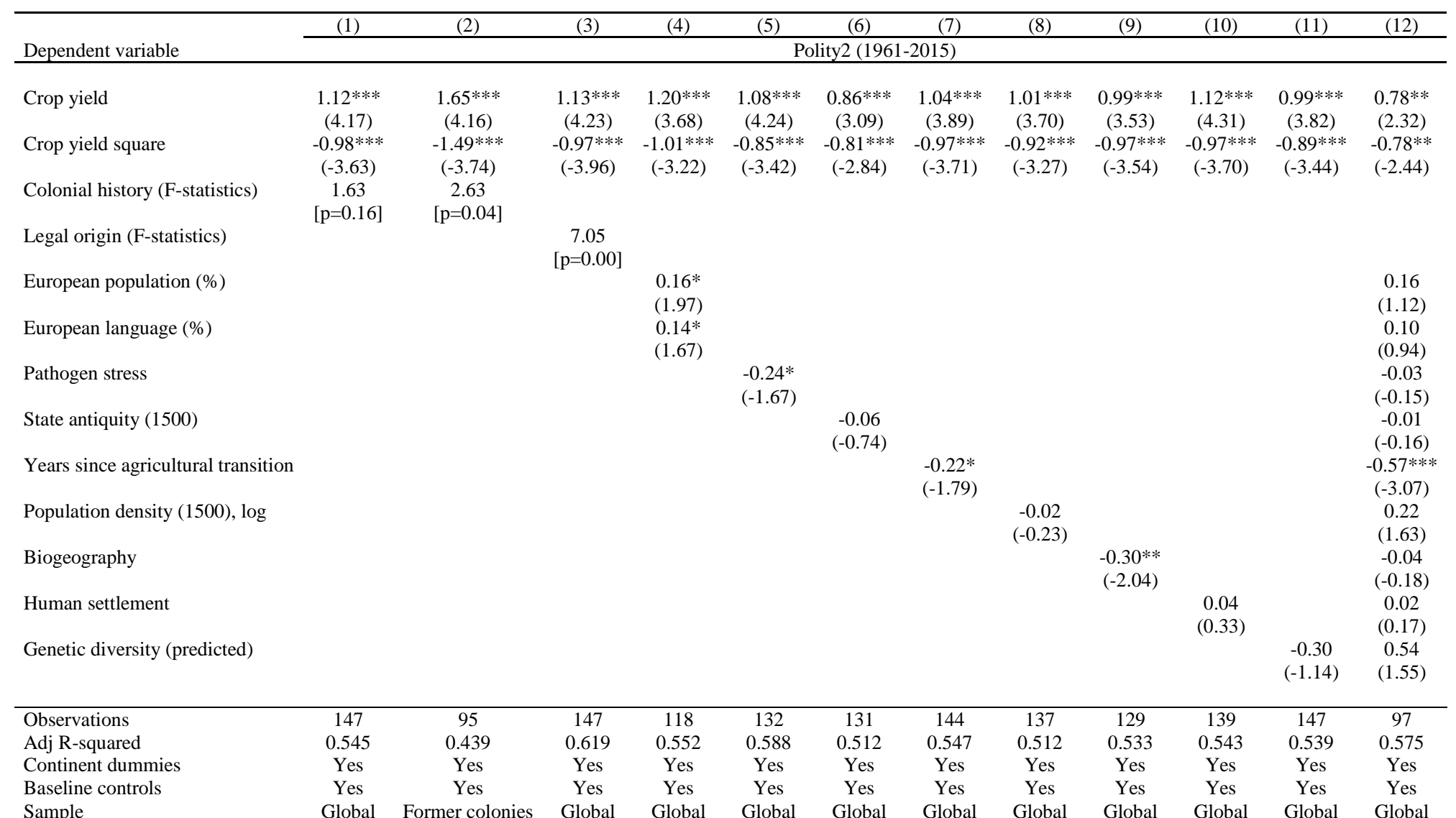

Notes: This table presents standardized coefficients for the effect of (mean) crop yield (measured in millions of kilocalories per hectare per year) on polity2 during 1961-2014.All specifications use an intercept term but not reported for brevity. The continent dummies are Africa, Asia, Australia, Europe, North America, Oceana, and South America. Baseline controls used are absolute latitude, terrain ruggedness, elevation (average), elevation (variation), landlockedness, distance to waterways. Robust z-statistics are given in parentheses. ***, **, * denote significance at the $1 \%$, $5 \%$, and $10 \%$ level, respectively. 
Hall and Jones (1999) argues that social infrastructure - institutions, and government policies - are endogenously determined by geography and other regional factors that can be captured by language. They compiled the share of European languages spoken in modern nations. In a similar vein, Easterly and Levine (2016) documents that the share of European population in colonies during colonization shaped the economic characteristics of these countries. We account for the possible confounding effects of these two channels on the extent of democracy in column (4). The number of observations reduces to 119 as the share of European languages is available for a smaller number of countries. We find that the share of European languages and the share of European population in colonies are statistically significant at $10 \%$ level. However, the coefficients of both the control variables - share of European languages, and share of European population- are much smaller than the coefficients of linear and square term of potential crop yield. The hump-shaped influence of the potential crop yield on the extent of democracy remains intact ${ }^{32}$.

Health conditions of population and early disease environment of nations are identified to affect development of institutions (Acemoglu, Johnson and Robinson (2003)). We account for disease environment measured by pathogen stress in column (5). Our hypothesis that crop yield has inverted-U shaped influence on the extent of democracy continues to hold.

Next, we focus on various measures of early development that can act as possible confounder in our model specification. We account for five measures of early development that are strongly correlated with current economic development, social

\footnotetext{
${ }^{32} \mathrm{We}$ also control one variable at a time separately and we do not find any significant qualitative change in our results.
} 
capital, and quality of institutions. The first is the state history in 1500 BCE. Ang (2013b) provides evidence that early development of state has an influence on the development of contemporary institutions. We use presence of state history variable constructed by Chanda and Putterman (2007). This index reflects whether there was a government, how much territory it covered, and whether the government was indigenous or externally imposed. They divide the period 1-1500 into 50 years periods and discount the past experience of having a state by $5 \%$ for each half century. Column (6) reports our findings of hump-shaped influence of crop yield on extent of democracy after accounting for state history in 1500 BCE.

The second measure of early development that we account for is the number of years since society in a country started sedentary agricultural practices, leaving huntergathering life style, and started getting most of their food needed from cultivated crops. Years since transition to agriculture can strongly explain comparative financial development, technological advancement, income level (Ang (2013a); Ang (2015); Putterman (2008)). We account for this in column (7), and find that there is no qualitative change in our results.

The third measure of early development is the population density in 1500 in estimation. Malthusian proposition suggests that higher agricultural productivity resulted into higher fertility, lower mortality, and population growth, rather than any economic development. Column (8) shows influence of crop yield on the extant of democracy remains robust after accounting for population density.

Next, Olsson and Hibbs (2005) establish that the initial bio-geographical conditions influenced contemporary levels of economic development through early transition to agriculture. Further, Ahlerup and Olsson (2012) show that the duration of human settlement in a region is negatively associated with the level of ethnic diversity in the 
region. This influences contemporary development indicators. We account for these two early development indicators in column (10) and column (11), respectively. The results indicate that the inverted-U shaped association between crop yield and the extent of democracy survives after accounting for these early development indicators. Further, we account for the influence of genetic diversity on extent of democracy in column (9). Genetic diversity was determined tens of thousands of year ago by the human society that was migrating out of Africa. Literature suggests that genetic diversity place an important role in the determination of contemporary productivity, economic development, ethnic conflicts, and hierarchy in the society (Ashraf and Galor (2013); Ashraf, Galor and Klemp (2015); Ashraf and Galor (2011); Arbatli, Ashraf and Galor (2015); Galor and Klemp (2015)). Our findings suggest that the hump-shaped influence of crop yield on extent of democracy is robust and statistically significant after accounting for genetic diversity. 
Table 4-4 Influence of crop yield on democracy after accounting for early development

\begin{tabular}{|c|c|c|c|c|c|c|c|}
\hline \multirow[b]{2}{*}{ Dependent variable } & (1) & (2) & (3) & (4) & (5) & (6) & (7) \\
\hline & \multicolumn{7}{|c|}{ Polity2 (1961-2015) } \\
\hline Crop yield & $\begin{array}{c}1.05 * * * \\
(3.82)\end{array}$ & $\begin{array}{c}0.86^{* * * *} \\
(3.09)\end{array}$ & $\begin{array}{c}1.02 * * * \\
(3.82)\end{array}$ & $\begin{array}{c}0.94 * * * \\
(3.57)\end{array}$ & $\begin{array}{c}1.40 * * * \\
(4.81)\end{array}$ & $\begin{array}{c}1.49 * * * \\
(5.71)\end{array}$ & $\begin{array}{c}0.96^{* * * *} \\
(3.69)\end{array}$ \\
\hline Crop yield square & $\begin{array}{c}-0.83 * * * \\
(-3.18)\end{array}$ & $\begin{array}{c}-0.87 * * * \\
(-3.07)\end{array}$ & $\begin{array}{c}-0.96 * * * \\
(-3.65)\end{array}$ & $\begin{array}{c}-0.86 \text { *** } \\
(-3.28)\end{array}$ & $\begin{array}{c}-1.24 * * * \\
(-4.36)\end{array}$ & $\begin{array}{c}-1.32 * * * \\
(-4.97)\end{array}$ & $\begin{array}{c}-0.87 * * * \\
(-3.33)\end{array}$ \\
\hline Pathogen stress & $\begin{array}{c}-0.23 \\
(-1.60)\end{array}$ & & & & & & \\
\hline Pathogen stress squarer & $\begin{array}{c}0.03 \\
(0.39)\end{array}$ & & & & & & \\
\hline State antiquity (1500) & & $\begin{array}{c}-0.54 * * \\
(-2.05)\end{array}$ & & & & & \\
\hline State antiquity (1500)square & & $\begin{array}{l}0.45^{*} \\
(1.80)\end{array}$ & & & & & \\
\hline Years since agri trans & & & $\begin{array}{c}-0.41 \\
(-1.13)\end{array}$ & & & & \\
\hline Years since agri trans square & & & $\begin{array}{c}0.18 \\
(0.50)\end{array}$ & & & & \\
\hline Population density (1500), log & & & & $\begin{array}{c}-0.24 * * \\
(-2.25)\end{array}$ & & & \\
\hline Population density (1500), log square & & & & $\begin{array}{c}0.31 * * * \\
(4.49)\end{array}$ & & & \\
\hline Biogeography & & & & & $\begin{array}{c}0.21 \\
(0.29)\end{array}$ & & \\
\hline Biogeography square & & & & & $\begin{array}{c}0.13 \\
(0.18)\end{array}$ & & \\
\hline Human settlement & & & & & & $\begin{array}{c}-1.10 * * * \\
(-3.17)\end{array}$ & \\
\hline Human settlement square & & & & & & $\begin{array}{c}0.70 * * \\
(2.01)\end{array}$ & \\
\hline Genetic diversity (predicted) & & & & & & & $\begin{array}{c}2.94 \\
(0.99)\end{array}$ \\
\hline Genetic diversity (predicted) square & & & & & & & $\begin{array}{c}-3.08 \\
(-1.09)\end{array}$ \\
\hline Observations & 132 & 131 & 144 & 137 & 129 & 139 & 147 \\
\hline Adj R-squared & 0.585 & 0.520 & 0.545 & 0.570 & 0.221 & 0.366 & 0.538 \\
\hline Continent dummies & Yes & Yes & Yes & Yes & Yes & Yes & Yes \\
\hline Baseline controls & Yes & Yes & Yes & Yes & Yes & Yes & Yes \\
\hline $\begin{array}{l}\text { Notes: This table presents standar } \\
\text { millions of kilocalories per hectar } \\
\text { intercept term but not reported for } \\
\text { North America, Oceana, and Sol } \\
\text { ruggedness, elevation (average), el } \\
\text { statistics are given in parentheses } \\
\text { respectively. }\end{array}$ & $\begin{array}{l}\text { dized coe } \\
\text { e per yea } \\
\text { brevity. T } \\
\text { uth Ameri } \\
\text { evation (v } \\
\text { s. **, ** }\end{array}$ & $\begin{array}{l}\text { fficients } f( \\
\text { ) on polit } \\
\text { he contine } \\
\text { ca. Baseli } \\
\text { ariation), } 1 \\
\text { * denot }\end{array}$ & $\begin{array}{l}\text { or the eff } \\
\text { ty } 2 \text { during } \\
\text { ent dumm } \\
\text { line contro } \\
\text { landlocked } \\
\text { te signific }\end{array}$ & $\begin{array}{l}\text { ect of }(\mathrm{m} \\
1961-20 \\
\text { ies are A } \\
\text { ls used } \\
\text { iness, dist } \\
\text { ance at t }\end{array}$ & $\begin{array}{l}\text { an) crop } \\
\text { 14. All sp } \\
\text { rica, Asia, } \\
\text { are absolu } \\
\text { ance to we } \\
\text { ee } 1 \%, 5 \%\end{array}$ & $\begin{array}{l}\text { yield (me } \\
\text { pecificatior } \\
\text { Australia } \\
\text { ate latitud } \\
\text { aterways. } \\
\% \text {, and } 10\end{array}$ & $\begin{array}{l}\text { asured in } \\
\text { as use an } \\
\text { Europe, } \\
\text { e, terrain } \\
\text { Robust z- } \\
\% \text { level, }\end{array}$ \\
\hline
\end{tabular}

Lastly, we account for recent developments in literature postulating that the association between the early development and contemporary economic development may be more complex and a concave relationship may be more appropriate (See, Ashraf and Galor (2013); Borcan, Olsson and Putterman (2016)). Following this pattern, we estimate alternative specification where we account for linear and squared 
variables for early development indicators - such as, state history, years since agricultural transition, population density, biogeography, duration since first human settlement, and predicted genetic diversity. The results are reported in 
Table 4-4. In all the specification, the linear and the squared coefficients of potential crop yield are statistically significant at $1 \%$ level after controlling for concave influence of early development indicators. In particular, state history, population density and early human settlement seem to have concave influence over the extent of democracy. Three early development indicators - disease environment, years since agricultural transition and biogeography had linear influence over the extent of democracy, but, the influence disappears when we use linear and squared variables together. Genetic diversity does not seem to have any influence over the extent of democracy. $54 \%$ of the cross-country variation in the extent of democracy can be explained by concave influence of potential crop yield over the extent of democracy. However, all these results need to be interpreted with caution as all the early development indicators are correlated with potential crop yield.

\subsubsection{Robustness to Contemporary Development and Social Cleavages}


A higher crop yield is likely to result in higher economic development and consequently promote democracy as argued by Lipset (1959). We account for economic development, measured by per capita GDP at the beginning of our period, that is, 1960, in column (1) of Table 4-5. The sample size has reduced to 95 countries as many countries in our global sample does not have per capita GDP data for 1960 in Penn World Tables (Feenstra, Inklaar and Timmer (2015)). Our findings support that GDP per capita is complementary to crop yield in explaining cross-country variation in extent of democracy ${ }^{33}$.We find that there is no qualitative change in the inverted $U$ shaped association between crop yield and extent of democracy over 1961-2015.

Table 4-5 Influence of crop yield on democracy after accounting for contemporary development and social cleavages

\begin{tabular}{|c|c|c|c|c|c|c|c|c|c|c|}
\hline \multirow[b]{2}{*}{ Dependent variable } & (1) & (2) & (3) & (4) & (5) & (6) & (7) & (8) & (9) & (10) \\
\hline & \multicolumn{10}{|c|}{ Polity2 (1961-2015) } \\
\hline Crop yield & $\begin{array}{c}0.90 * * * \\
(2.99)\end{array}$ & $\begin{array}{c}0.97 * * * \\
(3.26)\end{array}$ & $\begin{array}{c}0.94 * * * * \\
(3.76)\end{array}$ & $\begin{array}{c}1.37 * * * \\
(4.45)\end{array}$ & $\begin{array}{c}0.99 * * * \\
(3.67)\end{array}$ & $\begin{array}{c}0.89 * * * \\
(3.51)\end{array}$ & $\begin{array}{c}1.06 * * * \\
(4.31)\end{array}$ & $\begin{array}{c}1.10 * * * \\
(4.30)\end{array}$ & $\begin{array}{c}0.85^{* * * *} \\
(3.18)\end{array}$ & $\begin{array}{c}1.01 * * * \\
(3.92)\end{array}$ \\
\hline Crop yield square & $\begin{array}{c}-0.80^{* * *} \\
(-2.62)\end{array}$ & $\begin{array}{c}-0.86^{* * * *} \\
(-2.99)\end{array}$ & $\begin{array}{c}-0.83 * * * * \\
(-3.32)\end{array}$ & $\begin{array}{c}-1.15^{* * * *} \\
(-3.63)\end{array}$ & $\begin{array}{c}-0.96 * * * \\
(-3.65)\end{array}$ & $\begin{array}{c}-0.76 * * * \\
(-3.03)\end{array}$ & $\begin{array}{c}-0.94 * * * \\
(-3.70)\end{array}$ & $\begin{array}{c}-0.96 * * * \\
(-3.67)\end{array}$ & $\begin{array}{c}-0.72 * * * \\
(-2.67)\end{array}$ & $\begin{array}{c}-0.89 * * * \\
(-3.39)\end{array}$ \\
\hline GDP per capita (1960) & $\begin{array}{l}0.23^{*} \\
(1.75)\end{array}$ & & & & & & & & & \\
\hline Years schooling (1960) & & $\begin{array}{c}0.45 * * * \\
(4.85)\end{array}$ & & & & & & & & \\
\hline Oil production/GDP & & & $\begin{array}{c}-0.12^{* * *} \\
(-2.11)\end{array}$ & & & & & & & \\
\hline Foreign aid (\% of GDP) & & & & $\begin{array}{c}0.02 \\
(0.26)\end{array}$ & & & & & & \\
\hline Religion (F-statistics) & & & & & $\begin{array}{c}3.06 \\
{[\mathrm{p}=0.02]}\end{array}$ & & & & & \\
\hline Ethnic fractionalization & & & & & & $\begin{array}{c}-0.10 \\
(-0.97)\end{array}$ & & & & \\
\hline Language fractionalization & & & & & & $\begin{array}{l}0.20^{*} \\
(1.68)\end{array}$ & & & & \\
\hline Religion fractionalization & & & & & & $\begin{array}{c}0.02 \\
(0.31)\end{array}$ & & & & \\
\hline Birthplace diversity & & & & & & & $\begin{array}{c}-0.08 \\
(-1.35)\end{array}$ & & & \\
\hline Emigration rate & & & & & & & & $\begin{array}{c}-0.05 \\
(-1.06)\end{array}$ & & \\
\hline Crop yield variation & & & & & & & & & $\begin{array}{l}0.15^{*} \\
(1.82)\end{array}$ & \\
\hline Irrigation (1900) (\%) & & & & & & & & & & $\begin{array}{l}-0.04 * \\
(-1.87) \\
\end{array}$ \\
\hline Observations & 95 & 124 & 145 & 121 & 146 & 140 & 146 & 145 & 147 & 147 \\
\hline Adj R-squared & 0.583 & 0.605 & 0.558 & 0.416 & 0.562 & 0.565 & 0.550 & 0.541 & 0.543 & 0.535 \\
\hline Continent dummies & Yes & Yes & Yes & Yes & Yes & Yes & Yes & Yes & Yes & No \\
\hline Baseline controls & Yes & Yes & Yes & Yes & Yes & Yes & Yes & Yes & Yes & Yes \\
\hline
\end{tabular}

Notes: This table presents standardized coefficients for the effect of (mean) crop yield (measured in millions of kilocalories per hectare per year) on polity2 during 1961-2015. All specifications use an intercept term but not reported for brevity. The continent dummies are Africa, Asia, Australia, Europe, North America, Oceana, and South America. Baseline controls used are absolute latitude, terrain ruggedness, elevation (average), elevation (variation), landlockedness, distance to waterways. Religion accounts for Protestant, Roman Catholic, Muslim, and Hindu. Robust z-statistics are given in parentheses. $* * *, * *, *$ denotes significance at the $1 \%, 5 \%$, and $10 \%$ level, respectively.

\footnotetext{
${ }^{33}$ We get similar results when we use average GDP per capita for period 1961-2015.
} 
Influence of education on political regime is not clear from existing literature. On one hand, education is argued to promote the development of "culture of democracy" (John Dewey (1916)). Lipset (1959) also argues that educated people understand the need of norms of tolerance and they make more rational electoral choices as education broadens people's outlook. He goes even further and suggests that education is "close to being a necessary condition" for democracy. In an empirical exercise, Castelló-Climent (2008) finds a positive association between education and democracy when he controls for the distribution of education among population over age of 25 years. In a recent paper, Murtin and Wacziarg (2014) find that education does promote democracy over a long period, 1870-2000. On the contrary, Acemoglu, Johnson et al. (2005) find no effect of education on democracy in a panel study. They argue that the statistical association between education and democracy in previous studies disappear when they introduce the time and the country for fixed effects in their studies. However, their study does not reject the possibility of causal relationship between education and democracy in long-term. So, it is difficult to expect the sign of coefficient for education control a priori. We control for average number of years of schooling in 1960 to account for any confounding effect of education on the extent of democracy. Our findings in column (2) show that the influence of crop yields on democracy is robust and statistically significant after accounting for average level of schooling in 1960. Our results suggest that average 
number of years in school (in 1960) is also complementary to crop yield and seems to promote democracy ${ }^{34}$.

Several studies highlight negative association between production of oil in a country and extent of democracy (e.g. Barro (1999); Ross (2001); Tsui (2011); Van der Ploeg (2011)). Tsui (2011) finds that discovery of 100 billion barrels new oil pushes down the democracy level of a country after three decades by $20 \%$. Many countries in global sample produce oil or have large oil reserves. To mitigate any confounding effect because of oil, we account for average oil income as a proportion of GDP over 1961- 2015 period in column (3). A large income coming from oil production has negative association with democracy and oil income explains cross-country variation in contemporary democracy at $5 \%$ significant level as established in literature ${ }^{35}$. However, hump-shaped influence of crop yield on democracy remains robust.

The main objective of foreign aid is to promote economic growth and improve institutional quality in the recipient country. However, recent studies have questioned the effectiveness of foreign aid in achieving the objective. Some studies suggest that the foreign aid might be counterproductive to the main objectives as adverse spillover effects offset any benefits from capital infusion (Svensson (2000); Rajan and Subramanian (2007); Young and Sheehan (2014)). Nunn and Qian (2014) document that US food aid seems to prolong intrastate civil conflicts as the rebel groups gets a large proportion of the food aid and it helps them in sustaining their fight against the government. We account for average foreign aid (net official development aid as a

\footnotetext{
${ }^{34}$ Our results hold for average number of years in primary, secondary, and higher education as well. Our results also hold when we use mean of 'average number of year of schooling' over period 19612015.

${ }^{35}$ We get similar results when we control for large proportion of export income (>1/3 of export) coming from export of oil endowment.
} 
fraction of recipient country's GDP) over period 1961-2015 in our specification in column (4) to control for any confounding effect of foreign aid on political regime. We find that the inverted U-shaped influence of crop yield on extent of democracy remains unaffected.

Recent studies highlight that religion and political regime of a country have positive association. Several studies highlight the role of protestant missionaries in the spread and development of many moral and cultural values that were inducive to the development of democracy. For instance, emphasis on reading bible in vernacular languages promoted education and printing press - that are foundation of modern democracy (Woodberry (2012)). Some studies establish that Islam promotes cultural values that are impediments to democratic regimes (Barro (1999); Karatnycky (2002)). There is a perception of strong association between Islam and authoritative institutions. However, observations from survey data provides contrary results (Rowley and Smith (2009)). To account for the influence of religion on democracy, we control for percentage of population that follows protestant Christianity, Roman Catholic, Islam, and Hindu in column (5). Our results show that the hump-shaped influence of crop yield on the extent of democracy remains robust. P-value of Wald test suggests that religions have complementary role to crop yield. We also tried to control for a single religion at the time and find that our results are unaffected.

Next, we control for potentially confounding measures of heterogeneity of population. Some of the most common measures of diversity are ethnic fractionalization, linguistic fractionalization, and religious fractionalization constructed by Alesina, Devleeschauwer et al. (2003) and Fearon (2003). Essentially, all these indices indicate the probability of finding two similar persons, based on different criteria, in a population. Diversity in population is found to have positive 
and negative effects. Ethnic diversity and linguistic diversity are identified as detrimental to economic growth and impede the development of high quality institutions (Easterly and Levine (1997); Collier (2001)). However, in a survey study, Alesina and Ferrara (2005) also find positive effect of population diversity on economic performance of social diversity in rich countries. Michalopoulos (2012) establishes that geography and climatic conditions of a region play an important role in the development of socio-cultural cleavages. We control for ethnic, linguistic, and religious fractionalization in column (6), however, only language fractionalization happens to be significant at $10 \%$ level in our estimation and the inverted $\mathrm{U}$-shaped influence of crop yield on democracy remains robust and significant.

Further, in a recent paper, Alesina, Harnoss and Rapoport (2016) propose and construct a diversity index for place of birth of immigrants. They find that the birthplace diversity highly correlates with the economic property. Since, in recent decades, more people are migrating to different place, and this can possibly alter the cultural norms and practices of population a region, so, we control for the effect of birthplace diversity in column $(7)^{36}$. In a similar vein, Docquier, Lodigiani et al. (2016) propose that emigration rate has association with the development of institutions - namely, Freedom House's civil liberties and political rights, and Simon Fraser Institute's economic freedom of the world - in the country of origin. To account for any confounding effect of birthplace diversity on political regime, we control for birthplace diversity in our model specification and find that crop yield has an inverted U-shape and robust influence over the extent of democracy after

\footnotetext{
${ }^{36} \mathrm{We}$ present results using birthplace diversity for skilled migrants, however, our results are similar for other birthplace diversity indices.
} 
accounting for emigration rate in column (8). Emigration seems to have negative association with the level of democracy, but, this association is not significant. This needs to be interpreted with caution as many control variables are possibly confounding and the result might be biased for this reason.

Variation in crop yield is identified to exacerbate civil conflicts in earlier studies. Conflicts are known to affect various institutions and economic growth across countries. Easterly, Gatti and Kurlat (2006) find a relationship between democracy and mass killing. To account for any confounding effect of variation in crop yield on hump-shaped influence of crop yield on extent of democracy, we introduce variation in crop yield in our empirical specification. Surprisingly, our findings reported in column (9) suggest that variation in crop yield is positively associated with extent of democracy. However, there is no change in the association of crop yield and extent of democracy.

Lastly, we account for the irrigation facilities in 1900 in last column. In a recent

paper, Bentzen, Kaarsen and Wingender (2016) establish that a higher level of irrigation potential increases the possibility of an autocratic regime. They argue that irrigation facilities are an asset that can be appropriated and controlled by the elites in the society and this gives rise to a hierarchical society. Our findings in the last column (10) after accounting for percentage of land irrigated in 1900 show that the inverted U-shaped influence of crop yield on extent of democracy remains robust and statistically significant. Coefficient of irrigation has a negative sign, as expected, and it is significant at a $10 \%$ level of confidence, though the coefficient is much smaller in comparison to either of the coefficients of crop yield.

\subsubsection{Robustness to Restricted-Sample Estimation}


In this section, we estimate our regression model given by equation (1) after restricting the sample by various criteria. There is a possibility that our results specifically, with respect to the hump-shaped influence of crop yield on the extent of democracy- are driven by the inclusion of a particular region in our sample. To mitigate such concern, we drop the observations belonging to a particular continent sequentially and re-estimate our baseline model. Results after dropping one continent at a time are reported in column (2) to (7) of Table 4-7. Column (1) reports the baseline results with global sample for easy comparison. The estimates indicate that the hump-shaped influence of potential crop yield is statistically significant in all cases. Hence, we conclude that our results are not sensitive to the exclusion of observations from any particular continent.

Table 4-6 Influence of crop yield on democracy after omitting various regions

\begin{tabular}{|c|c|c|c|c|c|c|c|c|c|c|}
\hline & $(1)$ & $(2)$ & (3) & (4) & $(5)$ & (6) & $(7)$ & $(8)$ & $(9)$ & $(10)$ \\
\hline $\begin{array}{l}\text { Dependent } \\
\text { variable }\end{array}$ & \multicolumn{10}{|c|}{ Polity2 (1961-2015) } \\
\hline Crop yield & $\begin{array}{c}1.04 * * * \\
(4.05)\end{array}$ & $\begin{array}{c}1.27 * * * \\
(3.74)\end{array}$ & $\begin{array}{c}0.83 * * * \\
(3.19)\end{array}$ & $\begin{array}{c}1.08 * * * \\
(3.44)\end{array}$ & $\begin{array}{c}0.95 * * * \\
(3.64)\end{array}$ & $\begin{array}{c}1.00 * * * \\
(3.86)\end{array}$ & $\begin{array}{c}1.05 * * * \\
(4.03)\end{array}$ & $\begin{array}{c}0.97 * * * \\
(3.53)\end{array}$ & $\begin{array}{l}0.66 * * \\
(2.51)\end{array}$ & $\begin{array}{c}1.52 * * * \\
(3.51)\end{array}$ \\
\hline $\begin{array}{l}\text { Crop yield } \\
\text { square }\end{array}$ & $\begin{array}{c}- \\
0.91 * * * \\
(-3.46)\end{array}$ & $\begin{array}{c}- \\
1.04^{* * * *} \\
(-3.00)\end{array}$ & $\begin{array}{c}- \\
0.91^{* * * *} \\
(-3.39)\end{array}$ & $\begin{array}{c}- \\
0.92^{* * * *} \\
(-2.83)\end{array}$ & $\begin{array}{c}-0.80 * * * \\
(-3.03)\end{array}$ & $\begin{array}{c}-0.84 * * * \\
(-3.22)\end{array}$ & $\begin{array}{c}- \\
0.91 * * * \\
(-3.45)\end{array}$ & $\begin{array}{c}-0.80 * * * \\
(-2.90)\end{array}$ & $\begin{array}{l}-0.44 * \\
(-1.80)\end{array}$ & $\begin{array}{c}-1.31 \text { *** } \\
(-2.87)\end{array}$ \\
\hline Observations & 147 & 116 & 105 & 100 & 134 & 136 & 144 & 123 & 113 & 57 \\
\hline $\begin{array}{l}\text { Continent } \\
\text { dummies }\end{array}$ & Yes & Yes & Yes & Yes & Yes & Yes & Yes & Yes & Yes & Yes \\
\hline $\begin{array}{l}\text { Baseline } \\
\text { controls }\end{array}$ & Yes & Yes & Yes & Yes & Yes & Yes & Yes & Yes & Yes & Yes \\
\hline Adj R-squared & 0.537 & 0.342 & 0.668 & 0.496 & 0.565 & 0.537 & 0.525 & 0.537 & 0.570 & 0.533 \\
\hline $\begin{array}{l}\text { Omitted } \\
\text { continent }\end{array}$ & None & Europe & Asia & Africa & $\begin{array}{c}\mathrm{N} . \\
\text { America }\end{array}$ & $\begin{array}{c}\text { S. } \\
\text { America }\end{array}$ & Oceana & None & None & None \\
\hline Sample & Global & Global & Global & Global & Global & Global & Global & $\begin{array}{c}\text { Old } \\
\text { world }\end{array}$ & Native $>0.8$ & Industrial \\
\hline
\end{tabular}

Notes: This table presents standardized coefficients of (mean) crop yield (measured in millions of kilocalories per hectare per year) on various measures of democracy using OLS regression. Baseline controls used are absolute latitude, terrain ruggedness, elevation (average), elevation (variation), landlockedness, distance to waterways. All specifications use an intercept term but not reported for brevity. Robust t-statistics are given in parentheses. ***,**, * denotes significance at the $1 \%, 5 \%$, and $10 \%$ level, respectively. 


\subsection{Evidence from Precolonial Indigenous Societies}

This section presents the finding for the influence of crop yield on measures of democracy in precolonial societies for which relevant data is available in the Standard Cross-Cultural Sample (SCCS) compiled by Murdock and White (1969). The SCCS provides a representative sample of world cultures on 186 societies "for the earliest period for which satisfactory ethnographic data are available or can be constructed" in order to avoid the influence of European colonizers on these societies (Murdock and White (1969)). There is a possibility that the culture of these societies is being influenced after coming into contact with the Europeans as the year of observation for most of these societies are in nineteenth and early twentieth century. However, we can be reassured as the authors suggest "cultural independence of each unit in terms of historical origin and cultural diffusion could be considered maximal with respect to the others societies in the sample"

The database provides information on two important political dimensions. First, it provides information on the process of how "Local political succession" in these societies happened. The database categorizes the process of succession in nine different categories - namely, no headmen or council, by appointment, seniority, divination, informal consensus, electoral process, patrilineal, matrilineal, and hereditary without personal qualifications. We consider that the process of local political succession is democratic when it happens through 'informal consensus' or 'electoral process', otherwise not. Second, it provides information on who is the executive in the society - whether, council, 'executive and council', 'plural executives', or 'single leader'. We consider a society to be more democratic when the executive power is with a council, in the form of a current parliament in representative democracies, than with a 'single leader'. 
Table 4-7 Crop yield on democracy in Standard Cross Cultural Sample (SCCS)

\begin{tabular}{lcccccc}
\hline & $(1 \mathrm{a})$ & $(1 \mathrm{~b})$ & $(1 \mathrm{c})$ & $(2 \mathrm{a})$ & $(2 \mathrm{~b})$ & $(2 \mathrm{c})$ \\
\cline { 2 - 7 } Dependent variable & \multicolumn{5}{c}{ Local political succession } & \multicolumn{2}{c}{ Concentration of power in executive } \\
\hline \multirow{3}{*}{ Crop yield } & $0.59^{* *}$ & $0.58^{* *}$ & $0.56^{* *}$ & $0.73^{* *}$ & $1.18^{* *}$ & $1.24^{* * *}$ \\
& $(2.35)$ & $(1.96)$ & $(2.39)$ & $(2.49)$ & $(2.73)$ & $(2.17)$ \\
Crop yield square & $-0.62^{* * *}$ & $-0.59^{* *}$ & $-0.60^{* *}$ & $-0.62^{* *}$ & $-0.96^{* *}$ & $-0.93^{*}$ \\
& $(-2.69)$ & $(-2.36)$ & $(-2.61)$ & $(-2.60)$ & $(-2.56)$ & $(-1.77)$ \\
\hline Observations & 137 & 137 & 137 & 68 & 68 & 68 \\
Baseline controls & No & Yes & Yes & No & Yes & Yes \\
Region FE & No & No & Yes & No & No & Yes \\
R-squared & 0.03 & 0.06 & 0.18 & 0.05 & 0.13 & 0.24 \\
Language clusters & 40 & 40 & 40 & 24 & 24 & 24 \\
\hline
\end{tabular}

Notes: This table presents standardized coefficients for the effect of crop yield (measured in millions of kilocalories per hectare per year) on two alternative definition of democracy from Standard Cross Cultural Sample (SCCS). Baseline controls used are absolute latitude, terrain ruggedness, elevation (average), elevation (variation), landlockedness, distance to waterways. Latitude and elevation of the societies are used from SCCS database, while other controls - terrain ruggedness, elevation (variation), landlockedness, distance to waterways - are for the present country where these societies existed. The region dummies are Subsaharan Africa, Middle Old World, Southeast Asia/Insular Pacific, Sahul, North Eurasia/Circumpolar, Northwest Coast of NA, North and west of NA, Eastern Americas, Mesoamerica/Andes, and Far south America as described in SCCS database. All specifications use an intercept term but not reported for brevity. Standard errors are clustered at language group level. Robust t-statistics are given in parentheses. $* * *, * * *$ denote significance at the $1 \%, 5 \%$, and $10 \%$ level, respectively.

We use the same regression specification as described by equation (1) in crosscountry empirical analysis, except that the unit of analysis here is the society from SCCS database. The SCCS database does not have information about the land area these precolonial societies covered, however, we get a centroid of the society from the dataset. There is possibility of an error in measuring the precise location of the societies, so, following Alesina, Giuliano and Nunn (2013), we use a buffer zone of $200 \mathrm{~km}$ around the centroid of the societies to extract independent variable and other control variables from other datasets. The (mean) crop yield for a societies is calculated using this $200 \mathrm{~km}$ buffered land area around the centroid and the global crop yield dataset, a raster image, compiled and made available by Galor and Ozak (2015, 2016). Rest of the geographical control variables used in analysis are for the current country in which these societies exist ${ }^{37}$.

\footnotetext{
${ }^{37}$ A few more control variables - such as, elevation, distance from ocean - are also given in the SCCS database. As, the land area of these societies is not identified without error, so, these parameters
} 
Our findings of empirical estimation using this data for these precolonial societies are reported in Table 4-9. We replicate the process as we followed in Table 4-2 - first, look at the unconditional influence of crop yield on two variables, then, include all the baseline control variables, and finally, control for regional fixed effects, on two outcome variables discussed in this section. We find evidence of the hump-shaped influence of crop yield on measure of democracy in the precolonial societies as well. Statistical significance of linear and quadratic terms is not as strong as in the crosscountry analysis; however, the full model specification is able to explain up to 18 and 21 percent variation in the extent of democracy in precolonial societies.

\subsection{Transmission of Democracy from Precolonial Societies to Modern Nation- States}

Earlier, we established the hump-shaped association between crop yield and extent of democracy in cross-country and sub-national samples. The previous section takes this hypothesis further and establishes this association in pre-colonial societies. Now, the natural question is whether there is any persistence in the influence of crop yield on the extent of democracy from pre-colonial societies to modern nation states. We are aware of Persson and Tabellini (2009), Giuliano and Nunn (2013), and Bentzen, Hariri and Robinson (2015) who have answered exactly this question under different settings.

Persson and Tabellini (2009) proposed the concept of "democratic capital" that is "a slow accumulation of a stock of civic and social assets" which promotes the idea of democracy as a valuable form of political regime. They provide evidence to support

are likely to have measurement error. However, we use these variables in our specification model, and find that our results remain intact. 
their hypothesis that a country that became democratic early and remains a democracy is more likely to remain democracy in the future as well. Essentially, they argue that societies learn to respect democracy the longer they experience a democratic political regime. Giuliano and Nunn (2013) discover the persistence of democratic tradition from traditional preindustrial societies to modern nation-states. Using data from Ethnographic Atlas, they find that a higher proportion of traditional preindustrial societies where a local leader was chosen through a democratic process, political consensus or formal election, is likely to result in a democratic political regime in modern nation-states. They illustrate that the societies that had experienced democratic institutions in the past were more likely to have national democratic institutions. In a similar vein, Bentzen, Hariri and Robinson (2015) finds that the influence of traditional societies on modern institutions survives. However, they argue that this influence is not unconditional, but, there exists heterogeneity. They measured this heterogeneity by three characteristics of traditional ethnic groups distance of ethnic group from the capital of modern states, complexity of settlement of ethnic groups, and economic prosperity of ethnic groups. So, the institutions of all the traditional ethnic groups do not survive in modern states.

In the light of existing literature and our empirical evidences, we argue that the humpshaped association between crop yield and extent of democracy is a robust finding that existed since pre-colonial era, intergenerational transmission happened through social values to modern societies and persists in modern societies.

\subsection{Conclusions}

The political regime of a country, because of its endogeneity with other institutions in the country, attracts considerable attention in literature. The idea of democracy has 
existed for over two millenniums and has been practiced in various forms in different societies, though widespread democratization at national level is a recent phenomenon that started in the twentieth century. However, the causes of democratization at a national as well as a regional level are not well understood.

In this research, we argue that the many possible causes of democracy discussed in literature - such as, economic prosperity, human capital, social infrastructure, and culture - are themselves results of geographical conditions that are exogenous to human intervention. We propose and provide evidence that potential crop yield that is exogenous to a region was an essential endowment for the pre-colonial agricultural societies. However, an optimal level of endowment was required for promotion of democracies in societies. While a low level of crop yield endowment was not sufficient to promote democracy, at the same time, a very high level of crop yield was also counterproductive to the idea of democracy. So, we hypothesized an inverted Ushaped association between crop yield and the extent of democracy.

Our empirical findings support our hypothesis that the crop yield has a hump-shaped influence over the extent of democracy in cross-country, sub-national level, precolonial societies, and at the individual level. Our findings are robust to the inclusion of various confounding control variables, alternative definitions of democracy, and changes of the period of study from 1800 to recent years.

This research contributes to the extant literature on the influence of historical events on contemporary institutions. We highlight and establish the role of crop yield on democracy in present countries. 


\section{Data Appendix}

\section{A. Outcome variable}

Democracy (polity2): A composite index from the Polity IV project that is computed by subtracting the AUTOC score from the DEMOC score. The variable has possible values of -10 to +10 , where 10 indicates the largest degree of democracy (source: Marshall, Gurr and Jaggers (2015)).

Voter turnout: This is defined as the number of votes as a percent of total eligible voters registered in an area. Relevant data for USA and India are downloaded from following sources

USA: http://www.electproject.org/home/voter-turnout/voter-turnout-data, and India: http://eci.nic.in/eci_main1/ElectionStatistics.aspx

\section{B. Crop yield (main explanatory variable)}

This index captures maximum potential crop yield (measured in billions of kilocalories per hectare per year) across different regions in a country. Crop yield index is constructed using crop yield (measured in tons per hectare per year) from Global Agro-Ecological Zones (GAEZ) project of Food and Agriculture Organization (FAO) and caloric content of various crops from US Department of Agriculture Nutrient Database for Standard Reference (source: Galor and Özak (2016)).

\section{Geographic controls}

Distance to waterways. The distance, in thousands of $\mathrm{km}$, from a GIS grid cell to the nearest ice-free coastline or sea-navigable river, averaged across the grid cells of a country (source: Harvard University's CID Research Datasets on General Measures of Geography). 
Elevation. The average elevation of a country, in thousands of kilometers above sea level, calculated using geospatial data at a 1-degree resolution from the Geographically based Economic data (G-ECON) project.

Latitude. The absolute value of latitude of a country's centroid, as reported on http://gothos.info/resources.

Ruggedness. The calculation for ruggedness takes a point on the earth's surface and measures the difference in elevation between this point and each of the eight major directions of the compass (north, northeast, east, southeast, south, southwest, west, and northwest). The index at the central point is given by the square root of the sum of the squared differences in elevation between the central point and the eight adjacent points (source: Nunn and Puga (2012)).

\section{Additional controls}

Birthplace diversity: This index measures the probability that two individuals drawn randomly from the entire population have two different countries of birth (source: Alesina, Harnoss and Rapoport (2016))

Colonial history. A classification of a country's colonial origin into British, French, Portuguese, Spanish, or other European (i.e., Dutch, Belgian, and Italian) since 1700. For countries ruled by several colonial powers, the most recent one is taken provided that it was ruled for ten years or longer (source: Nunn and Puga (2012)).

Emigration rate: This variable is created by diving the total number of emigrants by the average population of the source country. (source: IAB brain-drain dataset (Brücker, Capuano and Marfouk (2013)))

Ethnic fractionalization. This is defined as the probability that two randomly selected individuals in a country will be from different ethnic groups (source: Fearon (2003)). 
Genetic diversity: An index that incorporates the expected heterozygosities of the precolonial ancestral populations of contemporary subnational groups as well as the pairwise genetic distances between these ancestral populations. (source: Ashraf and Galor (2013)

European population (\%): The fraction of a country's population having European ancestors during colonization (source: Easterly and Levine (2016))

European language (\%): The fraction of a country's population speaking one of the five primary Western European languages (i.e. English, French, German, Portuguese, and Spanish) as their first language (source: Hall and Jones (1999).

Foreign aid (\% of GDP): This variable is constructed using data on 'net official development assistance and official aid received' and GDP for recipient countries (source: World Bank).

GDP per capita: GDP per capita data at constant price (2005 US\$) (source: Feenstra, Inklaar and Timmer (2015)).

Irrigation (1900): This variable is created by dividing the area irrigated in $1900 \mathrm{AD}$ by land area of the country. The irrigated area and land area are retrieved from Siebert, Kummu et al. (2015) and World Bank respectively.

Language fractionalization. This index is constructed as: $\mathrm{F}=\sum_{i=1}^{m} n_{i}\left(1-n_{i}\right)$, where $n_{i}$ is the population share of group $i$ and $m$ is the number of groups (source: Esteban, Mayoral and Ray (2012)).

Legal origins. A classification of a country's legal tradition into British common law, French civil law, German civil law, Scandinavian law or Socialist law (source: La Porta, Silanes et al. (1998)).

Oil. A dummy variable indicating whether the proportion of export revenues from oil is larger than 1/3 (Fearon and Laitin (2003)). 
Pathogen stress: A standardized index of historical pathogen prevalence for nine diseases, including leishmanias, schistosomes, trypanosomes, leprosy, malaria, typhus, filariae, dengue, and tuberculosis (source: Murray and Schaller (2010)). Population density (1500): This variable is constructed by dividing total population in $1500 \mathrm{AD}$ by land area. The population in $1500 \mathrm{AD}$ and land area are retrieved from McEvedy and Jones (1978) and World Bank, respectively.

Religion (\% of population): This variable indicates the fraction of population following major religions in each country in year 2000 (source: The Association of Religion Data Archives).

Religion fractionalization: This variable is computed as one minus Herfindahl index of religious group shares. It reflects the probability that two randomly selected individuals from population belongs to different religion groups (source: Alesina, Devleeschauwer, et al. (2003)).

State Antiquity (1500): An index of state history covering the period between $1 \mathrm{AD}$ and 1500 AD. (source: Chanda and Putterman (2007))

Years since transition to agriculture: The number of years before 2000AD when the people of a country, today's territories, started getting more than half of their calories from cultivated foods and domesticated animals. (source: Putterman (2006))Years of schooling: Average number of years spent at school by 15 years or older people. (source:Barro and Lee (2013)) 


\section{Concluding remarks}

In this empirical exercise, I examine the role of land productivity, measured by potential crop yield, in the formation of cultural and institutional traits in the distant past. The productive land, and consequently agricultural productivity, was a key economic resource for agrarian societies before the advent of industrialization in developed countries. Productive land continues to hold an important and prestigious position in non-industrialised countries. It is natural for societies to control natural endowments, productive land in particular, to improve their own welfare and earn respect from others.

First, I identify that intrastate conflicts can be explained by unequal spatial distribution of land productivity within countries. When a small section of a country's populace governs the country, and controls the natural resources and their distribution, the rest of the country's populace will attempt to overthrow the establishment and take over the control of economic returns from natural endowments. Following this argument, I hypothesise that different section of societies would like to control more productive land and, in the process of attempting this, there is violent conflict. Some interesting addition to this work is also feasible in future using the potential crop yield in across different regions. For example, one can look at bilateral conflict between countries. It will be interesting to know if bilateral conflicts depend on the level or difference in potential crop yield between the two countries. In this case, one will have to decide what bilateral conflicts one is talking about. Whether to concentrate on bilateral conflicts between the neighbours or any combination of two countries? Should one look at proxy war, foreign state sponsored 
conflict as well? However, this will require a different conceptual framework and empirical design so it is suggested for future work.

Second, I look at the pattern of the timing of colonization. My analysis establishes that Western European colonisers were more likely to occupy and control territories that were more productive. Further, I also find that the highly productive territories were colonised for a longer duration. Finally, I study the impact of distribution of productive land on the contemporary level of democracy across countries. I establish that there is an optimal level of land productivity that supports democracy in a country. More specifically, I find that land productivity has a hump-shaped relationship with the extant of democracy.

This study focuses on a reduced form of relationship between land productivity and other outcome variables. However, there is a need to identify possible mediating channels to better understand the mechanism of interaction between land productivity and other outcome variables. Some of the possible channels are suggested in respective chapters. Further empirical exercise will be able to establish the validity of plausible mediating channels.

Cross-country analysis has its own limitations. I have tried to overcome these limitations using grid level and sub-national data. The required data was extracted using Geographical Information System (GIS) software. There is tremendous potential for GIS techniques in local data extraction for future research. Some other challenges can be overcome in future work. For example, a democracy index at a subnational level can be constructed, and my hypothesis can be retested at sub-national level. Some of the challenges may remain unresolved. For instance, lack of reliable territorial maps, and demographic data at subnational level will prevent the compilation of a colonization index at subnational level. 
Overall, this study contributes to the literature that examines the long-run impact of historic events and geographical endowment. A large population in developing countries still depends on agricultural practices; a better understanding of their land endowment may help in the development of culture and institutions that are more conducive for long-term economic growth. 


\section{REFERENCES}

ACEMOGLU, D., JOHNSON, S. \& ROBINSON, J. (2005). The Rise of Europe: Atlantic Trade, Institutional Change, and Economic Growth, American Economic Review 95, 546-579.

(2003). Disease and Development in Historic Perspective. Journal of the European Economic Association, 1(2-3), 397-405.

(2002). Reversal of Fortune: Geography and Institutions in the Making of the

Modern World Income Distribution, Quarterly Journal of Economics 117, 1231-1294. (2001). The Colonial Origins of Comparative Development: An Empirical Investigation, American Economic Review 91, 1369-1401.

ACEMOGLU, D., JOHNSON, S., ROBINSON, J. \& Yared, P. (2005). From Education to Democracy? American Economic Review, 95(2), 44-49.

ACEMOGLU, D., Naidu, S., Restrepo, P. \& Robinson, J. (2014). Democracy does Cause Growth, National Bureau of Economic Research (No. w20004)

Ahlerup, P. \& Olsson, O. (2012). The Roots of Ethnic Diversity, Journal of Economic Growth 17, 71102.

ALBERTO, A., \& FERRARA, E. (2005). Ethnic Diversity and Economic Performance. Journal of Economic Literature, 43(3), 762-800.

ALBERTO, A., GIULIANO, P. \& NUNN, N. (2013). On the Origins of Gender Roles: Women and the Plough. Quarterly Journal of Economics, 128(2), 469-530.

ALBERTO, A., HARNOSS, J. \& RAPOPORT, H.. (2016). Birthplace Diversity and Economic Prosperity. Journal of Economic Growth, 21(2), 101-38.

ALBION, R.G. (1926) Forests and Sea Power: The Timber Problem of the Royal Navy, 1652-1862 (Cambridge: Harvard University Press).

ALTONJI, J.G., ELDER, T.E. \& TABER, C.R. (2005). Selection on Observed and Unobserved Variables: Assessing the E_ectiveness of Catholic Schools, Journal of Political Economy 113, 151- 184.

Alesina, A., Devleeschauwer, A., Easterly, W., Kurlat, S. \& Wacziarg, R. (2003). Fractionalization, Journal of Economic Growth 8, 155-194.

ANG, J.B. (2015). What Drives the Historical Formation and Persistent Development of Territorial States?, Scandinavian Journal of Economics 117, 1134-1175.

ANG, J., (2015). Agricultural Transition and the Adoption of Primitive Technology. Economic Inquiry. 
. (2013a). Are Modern Financial Systems Shaped by State Antiquity? Journal of Banking \& Finance, 37(11), 4038-58.

. (2013b). Institutions and the Long-run Impact of Early Development. Journal of Development Economics, 105, 1-18.

ARBATli, C.E., Ashraf, Q.H. \& GAlOR, O. (2015). The Nature of Conflict, NBER Working Papers 21079.

ASHRAF, Q., \& GALOR, O. (2011). Dynamics and Stagnation in the Malthusian Epoch. American Economic Review, 101(5).

ASHRAF, Q., GALOR, O., \& KLEMP, M. (2015). Heterogeneity and Productivity. Brown University, Department of Economics, Working Paper.

ASHRAF, Q. \& GALOR, O. (2013). The "Out of Africa" Hypothesis, Human Genetic Diversity, and Comparative Economic Development, American Economic Review 103, 1-46.

ASHRAF, Q. \& MICHALOPOULOS, S. (2015). Climatic Fluctuations and the Diffusion of Agriculture, Review of Economics and Statistics 97, 589-609.

BAMFORD, P. (1956) Forests and French Sea Power 1660-1789 (Toronto: University of Toronto Press).

BARRO, R. (1999). Determinants of Democracy. Journal of Political Economy, 107(S6), S158-S83.

BARRO, R., \& LEE, J. (2013). A New Data Set of Educational Attainment in the World, 1950-2010. Journal of Development Economics, 104, 184-98.

BARRO, R. (2015). Convergence and Modernisation. Economic Journal, 125(585), 911-42.

BAYLY, C.A. (2004) The Birth of the Modern World, 1780-1914: Global Connections and Comparisons (Oxford: Blackwell).

BENTZEN, J., HARIRI, J. \& ROBINSON, J. (2015). The Indigenous Roots of Representative Democracy, National Bureau of Economic Research (No. w21193),

BENTZEN, J., KAARSEN, N., \& WINGENDER, A. (2016). Irrigation and Autocracy. Journal of the European Economic Association (Forthcoming).

BERTOCCHI, G. \& CANOVA, F. (2002). Did Colonization Matter for Growth?: An Empirical Exploration into the Historical Causes of Africa's Underdevelopment, European Economic Review

$46,1851-1871$. 
BESLEY, T. \& KUDAMATSU, M. (2006). Health and Democracy. American Economic Review, 96(2), 313-18.

Blattman, C. \& Miguel, E. (2010). Civil War, Journal of economic literature 48, 357.

Bockstette, V., Chanda, A. \& Putterman, L. (2002). States and Markets: The Advantage of an Early Start, Journal of Economic Growth 7, 347-369.

BOIX, C., MILlER, M. \& ROSATO, S. (2012). A Complete Data Set of Political Regimes, 1800-2007. Comparative Political Studies, 46(12), 1523 - 54.

BORCAN, O., OLSSON, O., \& PUTTERMAN, L. (2016). State History and Economic Development: Evidence from Six Millennia. Available at SSRN: https://ssrn.com/abstract=2464285

BROADBERRY, S., CAMPBELL, B.M., KLEIN, A., OVERTON, M. \& VAN LEEUWEN, B. (2015) British Economic Growth, 1270\{1870 (Cambridge: Cambridge University Press).

BRÜCKNER, M. (2010). Population Size and Civil Conflict Risk: Is there a Causal Link?, The Economic Journal 120, 535-550.

BRÜCKER, H., CAPUANO, S. \& MARFOUK. A. (2013). Education, Gender and International Migration: Insights from a Panel-dataset 1980-2010, mimeo. Retrieved August, 20, 2016.

BURBANK, J. \& COOPER, F. (2010) Empires in World History: Power and the Politics of Difference (Princeton: Princeton University Press).

BURNARD, T.G. (2001). 'Prodigious Riches': The Wealth of Jamaica Before the American Revolution, Economic History Review 506-524.

Cameron, A.C. \& Trivedi, P.K. (1986). Econometric Models Based on Count Data. Comparisons and Applications of Some Estimators and Tests, Journal of Applied Econometrics 1, 29-53.

CASTELLÓ-CLIMENT, A. (2008). On the Distribution of Education and Democracy. Journal of Development Economics, 87(2), 179-90.

Cervellati, M., Sunde, U. \& VAlmori, S. (2011). Disease Environment and Civil Conflicts, IZA Working Paper 5614.

CHANDA, A., COOK, C.J. \& PUTTERMAN, L. (2014). Persistence of Fortune: Accounting for Population Movements, There Was No Post-Columbian Reversal, American Economic Journal: Macroeconomics 6, 1-28. 
CHANDA, A. \& PUTTERMAN, L. (2007). Early Starts, Reversals and Catch-up in the Process of Economic Development. Scandinavian Journal of Economics, 109(2), 387-413.

Chaney, E. (2013). Revolt on the Nile: Economic Shocks, Religion, and Political Power, Econometrica 81, 2033-2053.

CHEIBUB, J., GANDHI, J. \& VREELAND, J. (2010). Democracy and Dictatorship Revisited. Public Choice, 143(1-2), 67-101.

Collier, P. \& Hoeffler, A. (1998). On Economic Causes of Civil War, Oxford Economic Papers 50, 563-573. (2004). Greed and Grievance in Civil War, Oxford Economic Papers 56, 563595.

CollieR, P. \& SAmbanis, N. (2002). Understanding Civil War: a New Agenda, Journal of Conflict Resolution 46, 3-12.

COMIN, D., EASTERLY, W. \& GONG, E. (2010). Was the Wealth of Nations Determined in 1000 BC?, American Economic Journal: Macroeconomics 2, 65-97. COOPER, J.F. (1860) The Sea Lions, or, The Lost Sealers (New York: Appleton). COX, D.R. \& OAKES, D. (1984) Analysis of Survival Data (Boca Raton: CRC Press).

CROSBY, A.W. (1986) Ecological Imperialism: The Biological Expansion of Europe, 900-1900 (Cambridge, UK: Cambridge University Press).

(1989). Reassessing 1492, American Quarterly 41, 661-669.

Dell, M., Jones, B.F. \& OlKEN, B.A. (2012). Temperature Shocks and Economic Growth: Evidence from the Last Half Century, American Economic Journal: Macroeconomics 4, 66-95.

DENEVAN, W.M. (1976) The Native Population of the Americas in 1492 (Madison: University of Wisconsin Press).

DEPETRIS-CHAUVIN, E. (2015). State history and contemporary conflict: Evidence from Sub-Saharan Africa, Available at SSRN: https://ssrn.com/abstract=2679594.

DePETRIS-Chauvin, E. \& ÖZAK, Ö. (2015). Population Diversity, Division of Labor and the Emergence of Trade and State, Available at SSRN: https://ssrn.com/abstract=2679382. 
(2016). The Origins and Long-Run Consequences of the Division of Labor, Available at SSRN: https://ssrn.com/abstract=2827328.

DER, G. \& EVERITT, B.S. (2005) Statistical Analysis of Medical Data Using SAS (Boca Raton: Chapman \& Hall/CRC).

DIAMOND, J. (1997) Guns, Steel and Germs: The Fate of Human Societies (New York: WW Norton \& Company).

DOCQUIER, F., LODIGIANI, E., RAPOPORT, H. \& SCHIFF, M. (2016). Emigration and Democracy. Journal of Development Economics, 120, 209-23.

DOW, G. \& REED, C. (2013). The Origins of Inequality: Insiders, Outsiders, Elites, and Commoners. Journal of Political Economy, 121(3), 609-41.

ENCYCLOPEDIA BRITANNICA (2017a). Black Death Retrieved from https://global.britannica.com/event/Black-Death (Accessed: April, 2017).

(2017b). Dutch East India Company Retrieved from https://global.britannica.com/topic/Dutch-East-India-Company (Accessed: April, 2017).

ENGERMAN, S.L. \& SOKOLOFF, K.L. (1997) Factor Endowments, Institutions, and Differential Paths of Growth Among New World Economies

ENGERMAN, S.L., SOKOLOFF, K.L., URQUIOLA, M. \& ACEMOGLU, D. (2002). Factor Endowments, Inequality, and Paths of Development among New World Economies [with Comments],

Economia 3, 41-109.

ERTAN, A., FISZBEIN, M. \& PUTTERMAN, L. (2016). Who was Colonized and When? A Cross-country Analysis of Determinants, European Economic Review 83, 165-184.

Esteban, J., Mayoral, L. \& Ray, D. (2012). Ethnicity and Conflict: An Empirical Study, American Economic Review 102, 1310-1342.

EASTERLY, W., GATTI, R. \& KURLAT, S. (2006). Development, Democracy, and Mass Killings. Journal of Economic Growth, 11(2), 129-56.

EASTERLY, W. \& LEVINE, R. (2016). The European Origins of Economic Development. Journal of Economic Growth, 21(3), 225-57.

FEARON, J.D. (2003). Ethnic and Cultural Diversity by Country, Journal of Economic Growth 8, 195-222. 
Fearon, J.D. \& Laitin, D.D. (2003). Ethnicity, Insurgency, and Civil War, American Political Science Review 97, 75-90.

FEENSTRA, R., INKLAAR, R. \& TIMMER, M. (2015). The Next Generation of the Penn World Table. American Economic Review, 105(10), 3150-82.

FEYRER, J. \& SACERDOTE, B. (2009). Colonialism and Modern Income: Islands as Natural Experiments, Review of Economics and Statistics 91, 245-262.

FIELDHOUSE, D.K. (1984) Economics and Empire, 1830-1914 (London: MacMillan Publishers).

FOGEL, R.W. \& ENGERMAN, S.L. (1974) Time on the Cross: The Economics of American Negro Slavery (New York: WW Norton \& Company).

GALLUP, J.L., MELLINGER, A.D. \& SACHS, J.D. (2010). Geography Datasets, Centre for International Development, Harvard University.

GALOR, O. \& ÖZAK, Ö. (2015). Land Productivity and Economic Development: Caloric Suitability vs. Agricultural Suitability, Brown University, Department of Economics Working Papers 2015-5.

(2016). The Agricultural Origins of Time Preference, American Economic Review 106, 3064-3103.

GALOR, O. \& KLEMP, M. (2015). Roots of autocracy. Brown University Department of Economics Working Paper, 7.

GALOR, O \& MOAV, M. (2007). The Neolithic Origins of Contemporary Variations in Life Expectancy. Working Papers 2007-14, Brown University, Department of Economics.

GIULIANO, P. \& NUNN, N. (2013). The Transmission of Democracy: from the Village to The Nation-State. American Economic Review, 103(3), 86-92.

GOULD, J.D. (1964). The Price Revolution Reconsidered, Economic History Review 17, 249-266.

GOVAN, T.P. (1942). Was Plantation Slavery Pro_table?, The Journal of Southern History 8, 513-535.

GOVERNMENT OF GOA INDIA (2017). Department of Tourism, Portuguese Conquests Retrieved from http://www.goatourism.gov.in/history/portugueseconquests (Accessed: April, 2017).

GRAMBSCH, P.M. \& THERNEAU, T.M. (1994). Proportional Hazards Tests and Diagnostics Based on Weighted Residuals, Biometrika 81, 515-526. 
GRIER, R.M. (1999). Colonial Legacies and Economic Growth, Public Choice 98, 317-335.

GURR, T.R. (2000). Ethnic Warfare on the Wane, Foreign Affairs 79, 52-64.

HALL, R.E. \& JONES, C.I. (1999). Why Do Some Countries Produce So Much More Output Per Worker Than Others?, Quarterly Journal of Economics 114, 83-116.

HAMILTON, E.J. (1934) American Treasure and the Price Revolution in Spain, 1501-1650 (Cambridge: Harvard University Press).

HANSEN, G.D. \& PRESCOTT, E.C. (2002). Malthus to Solow, American Economic Review 92, 1205-1217.

HARIRI, J.G. (2012). The Autocratic Legacy of Early Statehood, American Political Science Review 106, 471-494.

HARRISON, J. \& PARRY, J. (1968). Colonial Development and International Rivalries Outside Europe, The New Cambridge Modern History 3, 1559-1609.

HECKMAN, J.J. (1979). Sample Selection Bias as a Speci_cation Error, Econometrica 47, 153-161.

HERSH, J. \& VOTH, H.-J. (2009). Sweet Diversity: Colonial Goods and the Rise of European Living Standards after 1492 (July 4, 2009), Available at https://ssrn.com/abstract=1443730.

HIBBS, D.A., JR. \& OlSSON, O. (2004). Geography, Biogeography and Why Some Countries Are Rich and Others Poor, Proceedings of the National Academy of Sciences of the United States 101, 3715-3720.

HIGMAN, B.W. (2005) Plantation Jamaica, 1750-1850: Capital and Control in a Colonial Economy (Kingston: University of the West Indies Press Kingston).

HOUSE F. (2016). Freedom House. Online Data Retrieved on: 30th April 2016, 7, 2009.

Hsiang, S.M., Meng, K.C. \& CAnE, M.A. (2011). Civil Conflicts are Associated with the Global Climate, Nature 476, 438-441.

JOHNSON, A. \& EARLE, T. (2000). The Evolution of Human Societies: from Foraging Group to Agrarian State. Stanford University Press.

KAUFMANN, D ., KRAAY, A. , \& MASTRUZZI, M. , ( 2007 ). Governance matters VI: governance indicators for1996 - 2006 . World Bank Policy Research Working Paper No. 4280 . 
KEEFER, P. (2012). Database of Political Institutions. World Bank Working Paper Series, 2283.

LA PORTA, R., LOPEZ-DE-SILANES, F. \& SHLEIFER, A. (2008). The Economic Consequences of Legal Origins. Journal of Economic Literature, 46(2), 285-332.

LA Porta, R., Silanes, Florencio L.D., ANDREI SHLEIFER \& ROBERT W. VishnY (1998). Law and Finance, Journal of Political economy 106, 1113-1155.

LANDES, D.S. (1998) The Wealth and Poverty of Nations: Why Some Countries are so Rich and Some so poor (New York: WW Noton).

LANGE, M., MAHONEY, J. \& VOM HAU, M. (2006). Colonialism and Development: A Comparative Analysis of Spanish and British Colonies, American Journal of Sociology 111, 1412-1462.

LETENDRE, K., FincheR, C.L. \& ThORnhill, R. (2010). Does Infectious Disease Cause Global Variation in the Frequency of Intrastate Armed Conflict and Civil War?, Biological Reviews 85, 669-683.

LIVI-BACCI, M. (2012) A Concise History of World Population (Malden: John Wiley \& Sons).

McEvedy, C. \& Jones, R. (1978) Atlas of World Population History (New York: Facts on File).

LIPSET, S. (1959). Some Social Requisites of Democracy: Economic Development and Political Legitimacy. American Political Science Review, 53(01), 69-105.

LITINA, A. (2016). Natural Land Productivity, Cooperation and Comparative Development. Journal of Economic Growth (Forthcoming), 1-58.

MARSHALL, M., GURR, T. \& JAGGERS, K. (2015). Polity IV Project: Political Regime Characteristics and Transitions, 1800-2015. Dataset,

MCNEILL, W. (1998) Plagues and Peoples (New York: Anchor).

Michalopoulos, S. (2012). The Origins of Ethnolinguistic Diversity, American Economic Review 102, 1508-1539.

Miguel, E., Satyanath, S. \& Sergenti, E. (2004). Economic Shocks and Civil Conflict: An Instrumental Variables Approach, Journal of Political economy $112,725-753$.

MINTZ, S. (1985) Sweetness and Power: the Place of Sugar in World History (New York: Viking). 
MOKYR, J. (1981). Irish History with the Potato, Irish Economic and Social History $8,8-29$.

MURDOCK, G. \& WHITE, D. (1969). Standard Cross-Cultural Sample. Ethnology, 8(4), 329-69.

MURTIN, F. \& WACZIARG, R. 2014. The Democratic Transition. Journal of Economic Growth, 19(2), 141-81.

MuRRAY, D.R. \& SCHALlER, M. (2010). Historical Prevalence of Infectious Diseases within 230 Geopolitical Regions: A Tool for Investigating Origins of Culture, Journal of Cross-Cultural Psychology 41, 99-108.

NEF, J.U. (1977). Early Energy Crisis and its Consequences, Scienti_c American 237, 140-150.

NORTH, D.C. (1990) Institutions, Institutional Change and Economic Performance (Cambridge: Cambridge University Press).

NunN, N. \& PugA, D. (2012). Ruggedness: The Blessing of Bad Geography in Africa, Review of Economics and Statistics 94, 20-36.

NUNN, N. \& QIAN, N. (2010). The Columbian Exchange: A History of Disease,

Food, and Ideas, Journal of Economic Perspectives 24, 163-188.

(2011). The Potato's Contribution to Population and Urbanization: Evidence From A Historical Experiment, The Quarterly Journal of Economics 126, 593-650.

NunN, N. \& QIAN, N. (2014). US Food Aid and Civil Conflict, American Economic Review 104, 1630-1666.

NYU DEVELOPMENT RESEARCH INSTITUTE (2009). Global Development Network Growth Database.

Olsson, O. (2009). On the Democratic Legacy of Colonialism, Journal of Comparative Economics 37, 534-551.

Olsson, O. \& HIBBS, D.A. (2005). Biogeography and Long-Run Economic Development, European Economic Review 49, 909-938.

Olsson, O. \& PAIK, C. (2016). Long-Run Cultural Persistence: Evidence from the Neolithic Revolution, Journal of Development Economics, forthcoming.

OSTERHAMMEL, J. (2005) Colonialism: A Theoretical Overview (Princeton: Markus Wiener Publishers).

PAKENHAM, T. (1991) The Scramble for Africa (London: Weidenfeld \& Nicolson). 
PARKER, M. (2011) The Sugar Barons: Family, Corruption, Empire, and War in the West Indies (London: Hutchinson).

PERCY, G. \& QUINN, D.B. (1967) Observations Gathered Out of A Discourse of the Plantation of the Southern Colony in Virginia by the English, 1606 (Charlottesville: Association for the Preservation of Virginia Antiquities).

PERSSON, T. \& TABELlinI, G. (2009). Democratic Capital: The Nexus of Political and Economic Change. American Economic Journal: Macroeconomics, 1(2), 88-126.

Pettersson, T. \& Wallensteen, P. (2015). Armed Conflicts, 1946-2014, Journal of Peace Research 52, 536-550.

Posner, D.N. (2003). The Colonial Origins of Ethnic Cleavages: The Case of Linguistic Divisions in Zambia, Comparative Politics 35, 127-146.

PRICE, G.N. (2003). Economic Growth in a Cross-section of Nonindustrial Countries: Does Colonial Heritage Matter for Africa?, Review of Development Economics 7, 478-495.

PutTerman, L. (2006). Agricultural Transition Year Country Data Set, Brown University.

(2008). Agriculture, Diffusion and Development: Ripple Effects of the Neolithic Revolution, Economica 75, 729-748.

$\begin{array}{llllll} & \text { (2012). State Antiquity Index (Statehist) Version } 3.1\end{array}$ (http://www.econ.brown.edu/fac/louis putterman/).

PUTTERMAN, L. \& WEIL, D. (2010). Post-1500 Population Flows and The LongRun Determinants of Economic Growth and Inequality. Quarterly Journal of Economics, 125(4), 1627-82.

RAJAN, R. \& SUBRAMANIAN, A. (2007). Does Aid Affect Governance? American Economic Review, 97(2), 322-27.

Ramankutty, N., Foley, J.A., Norman, J. \& McSweEney, K. (2002). The Global Distribution of Cultivable Lands: Current Patterns and Sensitivity to Possible Climate Change, Global Ecology and Biogeography 11, 377-392.

ROSS, M. (2001). Does Oil Hinder Democracy? World Politics, 53(3), 325-61.

ROWLEY, C. \& SMITH, N. (2009). Islam's Democracy Paradox: Muslims Claim to Like Democracy, so Why do They Have so Little? Public Choice, 139(3-4), 273-99. 
SCHLENKER, W. \& LOBELL, D.B. (2010). Robust Negative Impacts of Climate Change on African Agriculture, Environmental Research Letters 5, 014010.

SIEBERT, S., KUMMU, M., PORKKA, M., DÖLL, P., RAMANKUTTY, N. \& SCANLON, B. (2015). A global data set of the extent of irrigated land from 1900 to 2005. Hydrology and Earth System Sciences, 19(3), 1521-45.

SIMONSOHN, U. (2016). Two-Lines: The First Valid Test of U-Shaped Relationships. University of Pennsylvania, mimeo.

SMITH, A. (1776) An Inquiry into the Nature and Causes of the Wealth of Nations (London: Methuen \& Co., Ltd.).

SOKOLOFF, K.L. \& ENGERMAN, S.L. (2000). History Lessons: Institutions, Factors Endowments, and Paths of Development in the New World, Journal of Economic Perspectives 14, 217-232.

SundBerg, R., ECK, K. \& KREUTZ, J. (2012). Introducing the UCDP Non-State Conflict Dataset, Journal of Peace Research 49, 351-362.

SUNDBERG, R. \& MELANDER, E. (2013). Introducing the UCDP Georeferenced Event Dataset, Journal of Peace Research 50, 523-532.

SVENSSON, J. (2000). Foreign Aid and Rent-seeking. Journal of International Economics, 51(2), 437-61.

TABELLINI, G. (2010). Culture and Institutions: Economic Development in the Regions of Europe. Journal of the European Economic Association, 8(4), 677-716.

TSUI, K. (2011). More Oil, Less Democracy: Evidence from Worldwide Crude Oil Discoveries. Economic Journal, 121(551), 89-115.

VAN DER PLOEG, F. (2011). Natural Resources: Curse or Blessing? Journal of Economic Literature, 49(2), 366-420.

WDI (2012) World Development Indicators 2012 Database (Philadelphia: World Bank).

Wimmer, A., Cederman, L.-E. \& Min, B. (2009). Ethnic Politics and Armed Conflict: a Configurational Analysis of a New Global Dataset, American Sociological Review 74, 316-337.

WoOlDRIDGE, J.M. (2010) Econometric Analysis of Cross Section and Panel Data (Cambridge, MA: MIT Press).

WOODBERRY, R. (2012). The Missionary Roots of Liberal Democracy. American Political Science Review, 106(02), 244-74. 
YOUNG, A. \& SHEEHAN, K. (2014). Foreign Aid, Institutional Quality, and Growth. European Journal of Political Economy, 36, 195-208.

Zhang, D.D., BRECKE, P., LEE, H.F., HE, Y.-Q. \& ZHANG, J. (2007). Global Climate Change, War, and Population Decline in Recent Human History, Proceedings of the National Academy of Sciences 104, 19214-19219. 